\title{
Stratigraphic Relations of the Navajo Sandstone to Middle Jurassic Formations, Southern Utah and Northern Arizona
}

GEOLOGICAL SURVEY PROFESSIONAL PAPER 1035-B
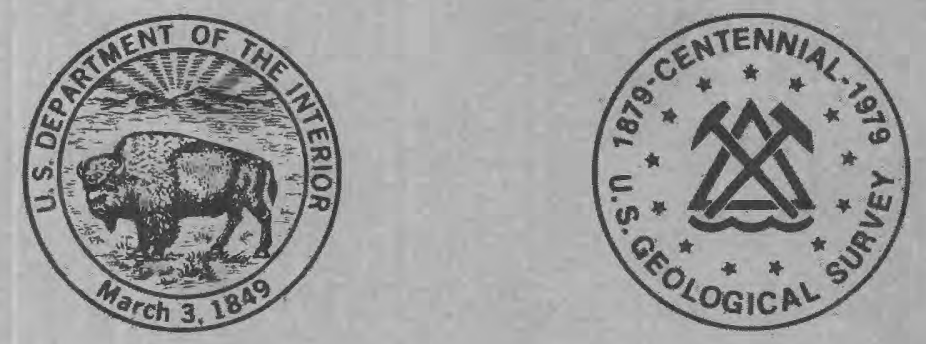



\section{Stratigraphic Relations of the Navajo Sandstone to Middle Jurassic Formations, Southern Utah and Northern Arizona}

By FRED PETERSON and G. N. PIPIRINGOS

UNCONFORMITIES, CORRELATION, AND NOMENCLATURE OF SOME TRIASSIC AND JURASSIC ROCKS, WESTERN INTERIOR UNITED STATES

GE OL OGICA L S UR VEY PR OFESS IONA L PA PER 1035-B

A reexamination of the stratigraphy

of formations that lie on the

Navajo Sandstone

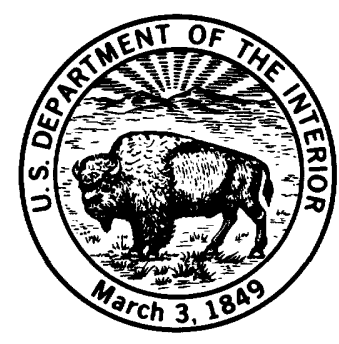




\title{
UNITED STATES DEPARTMENT OF THE INTERIOR
}

CECIL D. ANDRUS, Secretary

\section{GEOLOGICAL SURVEY}

\author{
H. William Menard, Director
}

Library of Congress Cataloging in Publication Data

Peterson, Fred.

Stratigraphic relations of the NavajoSandstone to Middle Jurassic formations, southern Utah and northern Arizona.

(Geological Survey Professional Paper 1035-B)

(Unconformities, correlation, and nomenclature of some Triassic and Jurassic rocks, western interior United States)

Bibliography: p. 42

Supt. of Docs. no.: I 19.16 1035-B

1. Geology, Stratigraphic-J urassic. 2. Geology-Utah. 3. Geology-Arizona.

I. Pipiringos, George Nicholas, 1918-joint author. II. Title III. Series. IV. Series : United States Geological Survey Professional Paper 1035-B.

QE681.P42 551.7'6

$77-608321$

For sale by the Superintendent of Documents, U.S. Government Printing Office

Washington, D.C. 20402

Stock Number 024-001-03198-1 


\section{CONTENTS}

Abstract

Introduction and acknowledgments $\ldots \ldots \ldots \ldots \ldots \ldots \ldots$

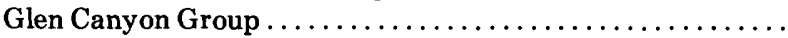

Navajo Sandstone..$\ldots \ldots \ldots \ldots \ldots \ldots \ldots \ldots \ldots \ldots \ldots$

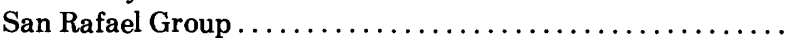

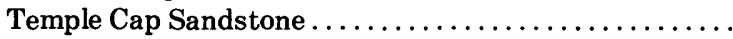

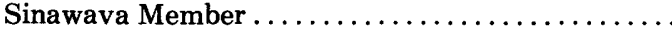
White Throne Member

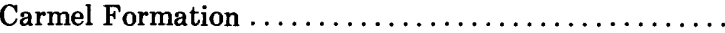

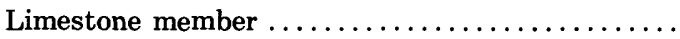
Judd Hollow Tongue $\ldots \ldots \ldots \ldots \ldots \ldots \ldots \ldots \ldots$ Banded member ........................... Gypsiferous member ....................... Winsor Member

Page
B1
2
4
4
6
6
8
9
10
11
11
13
14
14

San Rafael Group-Continued Carmel Formation -Continued

Upper member $\ldots \ldots \ldots \ldots \ldots \ldots \ldots \ldots \ldots \ldots \ldots, \quad$ B17

Page Sandstone $\ldots \ldots \ldots \ldots \ldots \ldots \ldots \ldots \ldots \ldots \ldots, \quad 20$

Harris Wash Tongue .................... 27

Thousand Pockets Tongue ................ $\quad 29$

Entrada Sandstone .......................... $\quad 30$

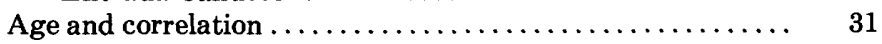

Glen Canyon Group ......................... 31

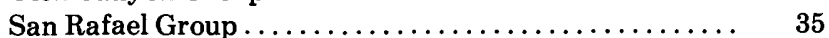

Name and location of measured sections ............ 36

Measured sections .......................... 38

References cited $\ldots \ldots \ldots \ldots \ldots \ldots \ldots \ldots \ldots \ldots \ldots, 42$

\section{ILLUSTRATIONS}

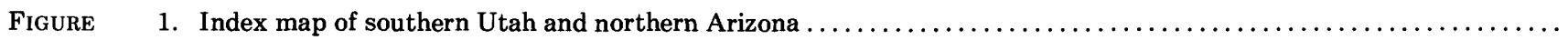

2. Restored section from Zion Canyon, Utah, to Red Rock, Arizona.

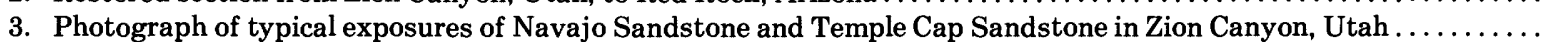

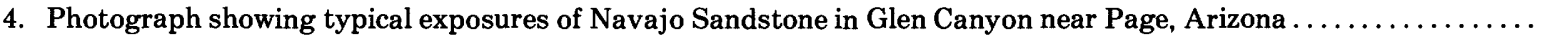

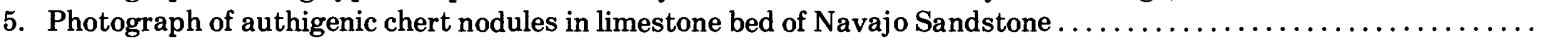

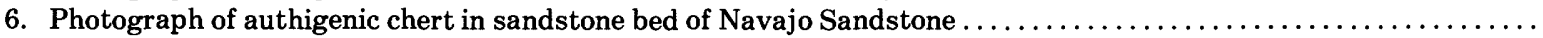

7. Photograph showing principal reference section of Temple Cap Sandstone and type section of Sinawava and White

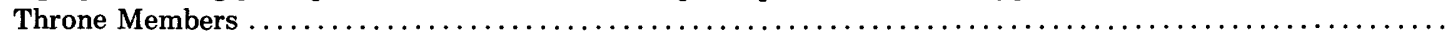

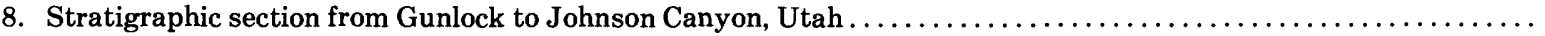

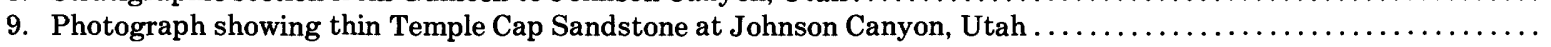

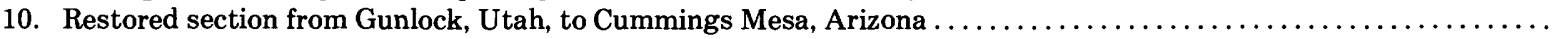

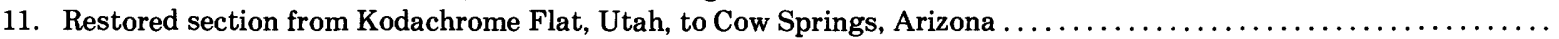

12. Photograph showing good exposures of banded member of Carmel Formation near Mount Carmel Junction, Utah .....

13. Photograph showing interfingering of banded member of Carmel Formation and lower part of Thousand Pockets

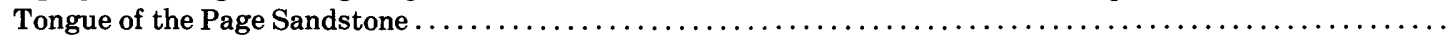

14. Photograph of the Thousand Pockets Tongue of the Page Sandstone and gypsiferous member of the Carmel

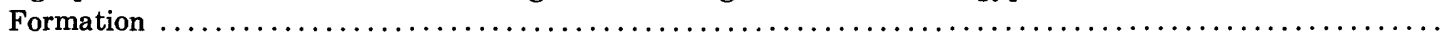

15. Photograph of reference section of Carmel Formation and Page Sandstone at Pine Creek near Escalante, Utah .....

16. Photograph showing typical exposure of upper member of Carmel Formation at Warm Creek .................

17. Photograph of good exposures of lower part of upper member of Carmel Formation southeast of Escalante, Utah ...

18. Photograph showing type section of Page Sandstone near Page, Arizona $\ldots \ldots \ldots \ldots \ldots \ldots \ldots \ldots \ldots \ldots \ldots$

19. Photograph showing evenly distributed small angular chert pebbles at base of Page Sandstone .................

20. Photograph of Glen Canyon at Crossing of the Fathers showing conspicuous notch or bench at contact of Page

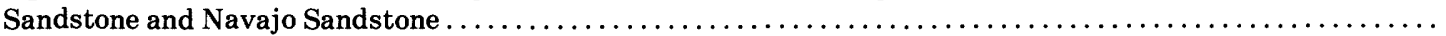

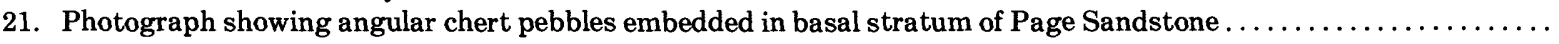

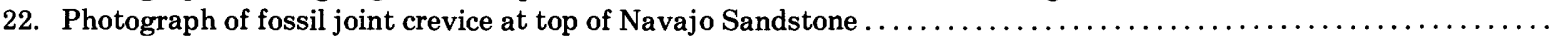

23. Photograph showing plan view of fossil joint crevices at top of Navajo Sandstone $\ldots \ldots \ldots \ldots \ldots \ldots \ldots \ldots \ldots \ldots$

24. Photograph showing conspicuous difference in colors of Navajo and Page Sandstones at Thousand Pockets ........

25. Photograph of Glen Canyon near Last Chance Creek showing color difference and topographic expression of Page

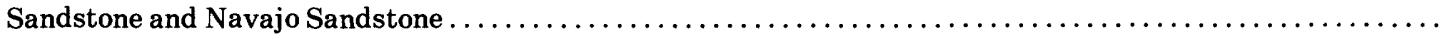

26. Photograph of small nodules in uppermost part of Navajo Sandstone near Page, Arizona ..................

27. Photograph showing buried hill of Navajo Sandstone on northeast side of Kaiparowits Plateau ................

28. Photograph of small buried ledge of Navajo Sandstone preserved beneath Page Sandstone on northeast side of Kaiparowits Plateau ...

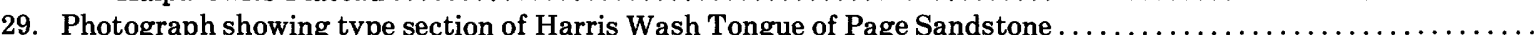

30. Diagram showing correlation of formations in Glen Canyon Group with European time-stratigraphic units .........

31. Chart showing correlation of rocks at selected sections in southwestern Utah and north-central Arizona with a section in southeastern Idaho, western Wyoming, and north-central Utah $\ldots \ldots \ldots \ldots \ldots \ldots \ldots \ldots \ldots \ldots$ 



\title{
STRATIGRAPHIC RELATIONS OF THE NAVAJO SANDSTONE TO MIDDLE JURASSIC FORMATIONS, SOUTHERN UTAH AND NORTHERN ARIZONA
}

\author{
By Fred Peterson and G. N. Pipiringos
}

\section{ABSTRACT}

Stratigraphic studies in southern Utah and northern Arizona indicate that the Navajo Sandstone does not intertongue with the overlying Middle Jurassic Carmel Formation. Two crossbedded sandstone bodies previously thought to be tongues of the Navajo in the Carmel are, instead, entirely separate from the Navajo. In addition, a regional unconformity is present at the base of the Carmel and equivalent formations. Thus, the Navajo is a predominantly crossbedded sandstone formation at the top of the Glen Canyon Group that does not intertongue with the Carmel Formation.

Early Jurassic palynomorphs were discovered in the Moenave Formation, which is at the base of the Glen Canyon Group in southwestern Utah and northwestern Arizona. These fossils indicate that the Moenave as well as the overlying Kayenta and Navajo Formations most likely are Early Jurassic in age and that considerably more of the Glen Canyon Group is Early Jurassic than had been thought before. However, the U.S. Geological Survey still considers the Navajo Triassic(?) and Jurassic in age pending further study of these plant fossils.

The Temple Cap Sandstone of southwestern Utah was formerly considered a member at the top of the Navajo Sandstone, but it is here given formation rank and included as the oldest formation in the San Rafael Group where it lies beneath the Carmel Formation. The Temple Cap is here divided into two newly named members: the Sinawava Member and the White Throne Member. The Sinawava, at the base of the formation, is flat bedded and consists of sandstone, silty sandstone, and mudstone, whereas the overlying White Throne Member consists of crossbedded sandstone. The White Throne grades westward into the Sinawava in the vicinity of the Hurricane Cliffs and west of the Hurricane Cliffs the Sinawava is the only member present. Contrary to previous reports, the White Throne is not a tongue of the Navajo; instead, the White Throne Member is separated from the Navajo by the Sinawava Member and neither member merges with the Navajo. In addition, the lower contact of the Sinawava, termed the J-1 surface, may be an unconformity, because it is a laterally continuous surface marked by broad irregularities that may have been caused by erosional processes. This surface is correlative with a similar surface in northeastern Utah and adjacent parts of Idaho and Wyoming that is considered an unconformity. The Temple Cap is unfossiliferous, but it is assigned an early Middle Jurassic age on the basis of correlation with the fossiliferous Gypsum Spring Member of the Twin Creek Limestone in north-central Utah.
A regional erosion surface termed the $\mathrm{J}-2$ unconformity bevels out the Temple Cap Sandstone in southwestern Utah and the Navajo Sandstone in southeastern Utah and northeastern Arizona. This surface is marked by a thin layer of small chert pebbles that are lag concentrates of chert nodules or pebbles derived from the underlying formations. Although it is widespread and occurs throughout most of the Western Interior, the J-2 unconformity probably was formed during a brief erosion interval in early Middle Jurassic time.

The Middle Jurassic Carmel Formation of the San Rafael Group lies on the J-2 unconformity in southwestern Utah. In this area, the Carmel contains, in ascending order, the limestone member, banded member, gypsiferous member, and Winsor Member. East of Cannonville, Utah, the equivalent of the limestone member is termed the Judd Hollow Tongue of the Carmel and southwest of Cannonville the banded member grades eastward into the Thousand Pockets Tongue of the Page Sandstone. Owing to facies changes east of the Paunsaugunt fault, strata that are equivalent to the gypsiferous member and Winsor Member farther west are termed the upper member of the Carmel Formation.

Some of the crossbedded sandstone beds in south-central Utah and north-central Arizona that were included in the upper part of the Navajo Sandstone were found to be separated from the underlying Navajo by the $\mathrm{J}-2$ unconformity. These beds comprise a discrete mappable unit and, accordingly, they are here removed from the Navajo, assigned formation rank, and named the Page Sandstone. The western part of the Page is divided into two westward-thinning tongues by the eastward-thinning Judd Hollow Tongue of the Carmel Formation. The lower tongue is here named the Harris Wash Tongue of the Page Sandstone; the upper tongue of the Page is the Thousand Pockets Tongue which was formerly considered a tongue of the Navajo Sandstone. The Page is laterally equivalent to the limestone and banded members of the Carmel Formation of southwestern Utah. Based on these relationships, the Page is here assigned a Middle Jurassic age and is placed in the San Rafael Group.

The upper member of the Carmel Formation lies conformably on the Page Sandstone in south-central Utah, but, progressing southeastward from this area, strata included in the lower part of the upper member interfinger with and gradually replace the Page. Farther southeast in north-central and northeastern Arizona, the lower beds of the upper member completely replace the Page so that the upper member rests directly on the Navajo Sandstone and is 
separated from the Navajo by the J-2 unconformity. Where it rests on the Thousand Pockets Tongue of the Page Sandstone, the upper member is equivalent to the gypsiferous member and Winsor Member of the Carmel of southwestern Utah; where it rests directly on the Navajo, the upper member probably is equivalent in age to most of the Carmel of southwestern Utah. These correlations indicate that the upper member of the Carmel Formation is Middle Jurassic in age.

\section{INTRODUCTION AND ACKNOWLEDGMENTS}

Stratigraphic studies on the Colorado Plateau over the past several decades yielded an anomalous stratigraphic relationship between the Navajo Sandstone and the overlying Carmel Formation. In southeastern Utah and northeastern Arizona, an unconformity separates the Navajo and Carmel, yet in southwestern Utah the upper Navajo and lower Carmel were thought to intertongue. Although this was explained as westward dying-out of the unconformity, recent fieldwork between the Hurricane Cliffs and the Kaiparowits Plateau (fig. 1) led to the discovery that the Navajo and Carmel do not intertongue and that the unconformity in southeastern Utah and northeastern Arizona does continue westward into southwestern Utah (fig. 2). Because of these findings, the stratigraphic relations of the Navajo Sandstone to the Carmel Formation must be reinterpreted. Because the stratigraphic relations determined by this study are so different from those published by Thompson and Stokes (1970), and because of ambiguities in their report, we do not use the names that they proposed for members of the Carmel Formation and Entrada Sandstone. Instead, we feel that the informal names suggested by Cashion (1967) are adequate.

Considerable emphasis in this study was placed on stratigraphic markers including marker surfaces and key beds or marker zones with distinctive lithologies or bedding characteristics. We used these markers to trace formation boundaries as well as member boundaries through areas where similar rock types are jux-

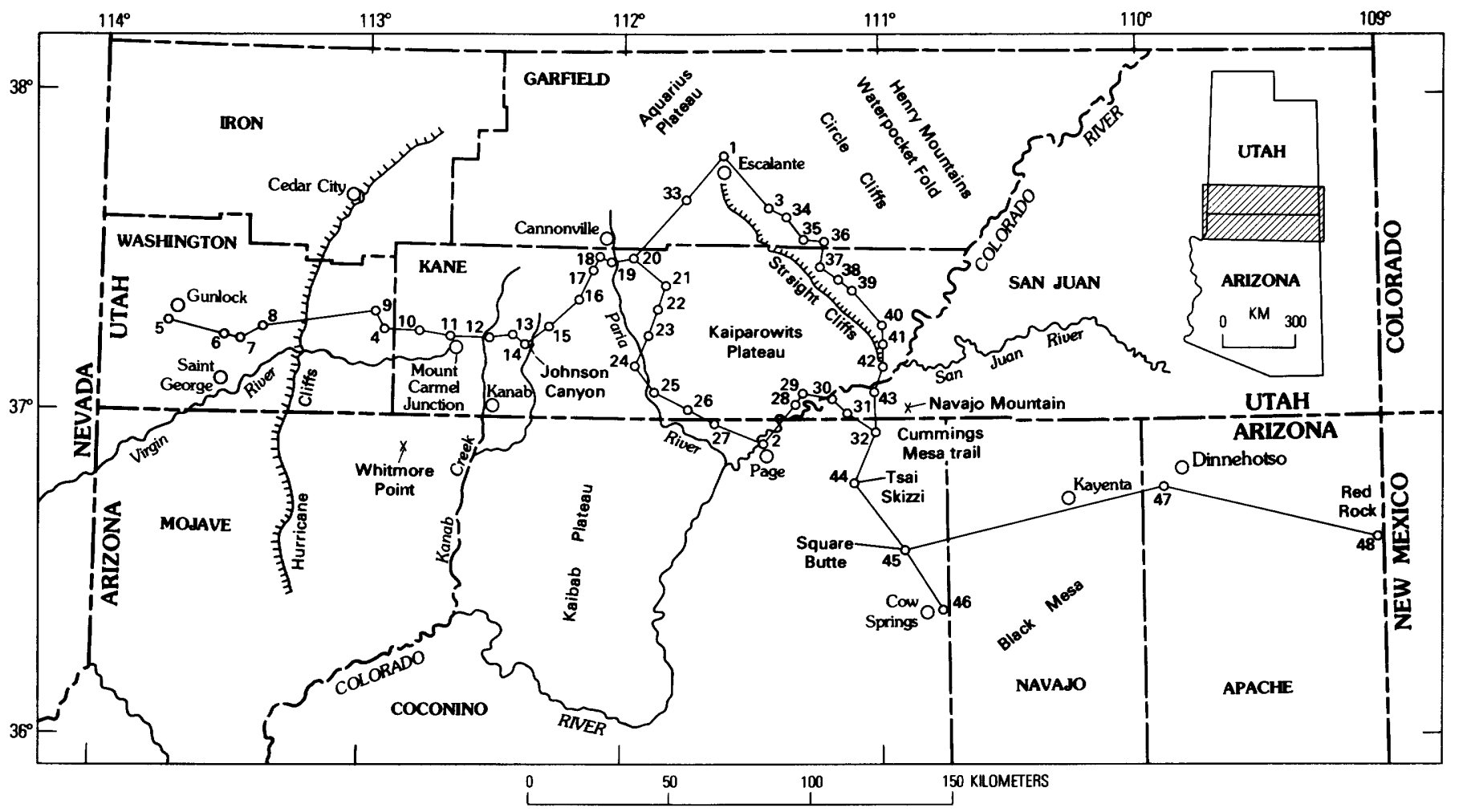

Figure 1.- Index map of southern Utah and northern Arizona showing location of measured sections and localities mentioned in the text. The names of the sections are listed below, and the locations are given in detail at the end of the report.

\begin{tabular}{|c|c|c|c|c|c|}
\hline 1. Pine Creek & 9. Potato Hollow & 17. Little Bull Valley & 25. East Cove & 33. Upper Valley & 41. Fiftymile Point \\
\hline 2. Page & 10. Meadow Creek & 18. Averett Canyon & 26. Judd Hollow & 34. Seep Flat & 42. Navajo Point \\
\hline 3. Harris Wash & 11. Mount Carmel Junction & 19. Sheep Creek & 27. Sand Valley & 35. Twentyfive Mile Wash & 43. Little Arch Canyo \\
\hline 4. Zion Canyon (Observation Point) & 12. Kanab Creek & 20. Kodachrome Flat & 28. Gunsight Butte & 36. Early Weed Bench & 44. Tsai Skizzi \\
\hline 5. Gunlock & 13. Brown Canyon & 21. The Gut & 29. Kane Wash & 37. Cat Pasture & 45. Square Butte \\
\hline 6. Diamond Valley & 14. Johnson Canyon & 22. Goodwater Seep & 30. Cummings Mesa NW & 38. Big Hollow Wash & 46. Cow Springs \\
\hline 7. Cottonwood Canyon & 15. Carly Knoll & 23. Hackberry Canyon & 31. West Canyon & 39. Hurricane Wash & 47. Dinnehotso \\
\hline 8. Danish Ranch & 16. Lick Wash & 24. West Cove & 32. Cummings Mesa Trail & 40. Cave Point & 48. Little Rock \\
\hline
\end{tabular}




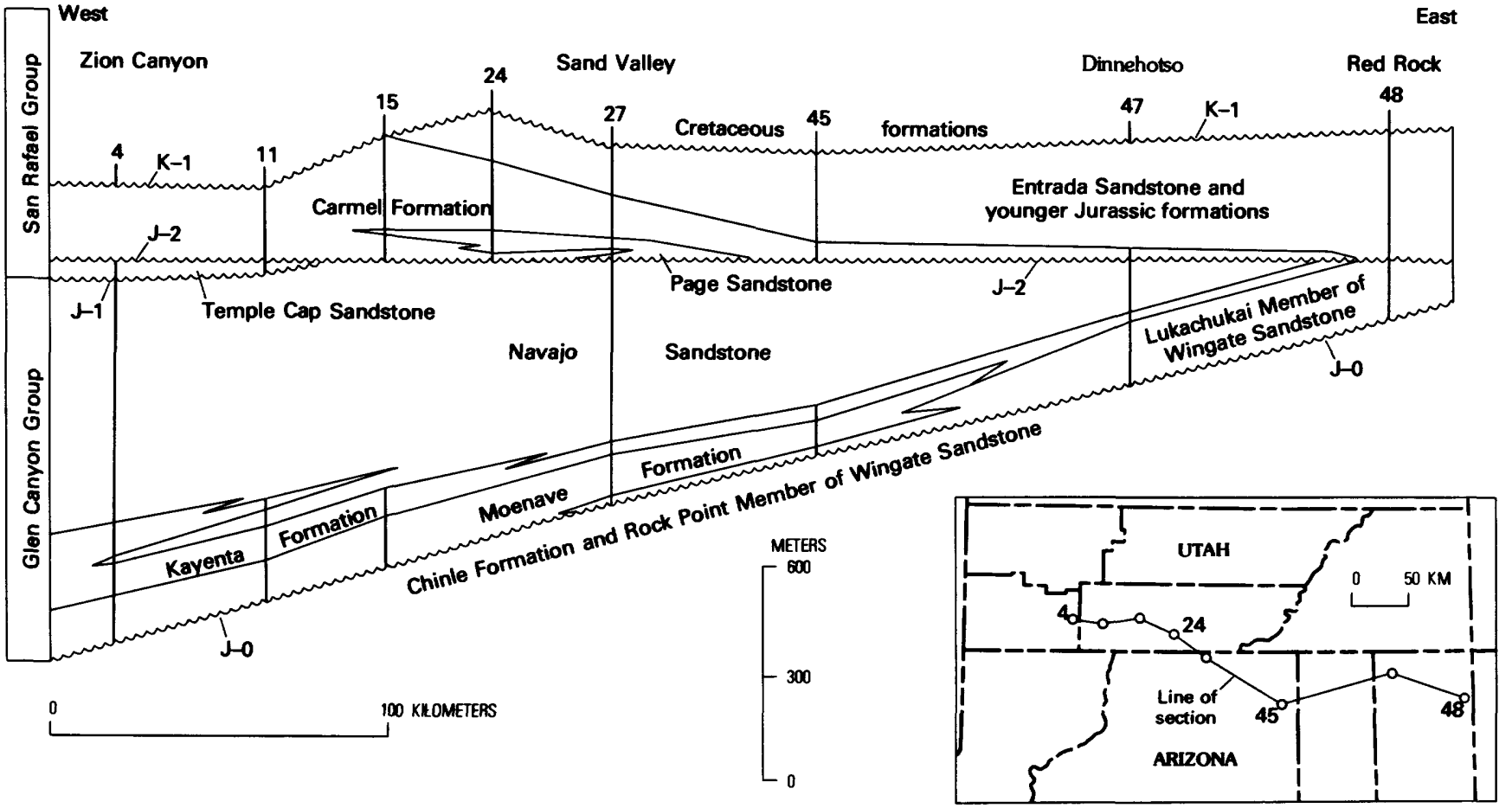

Figure 2.-Restored section of the Glen Canyon Group and lower part of the San Rafael Group showing continuity of J-0 and J-2 unconformities from northeastern Arizona to southwestern Utah. Stratigraphic relations in Glen Canyon Group after Harshbarger, Repenning, and Irwin (1957), Wilson (1965), and R. B. O'Sullivan (oral commun., 1970). Unconformity or probable unconformity shown by wavy line; J-0, J-1, J-2, and K-1 designate unconformities in Pipiringos and O'Sullivan (1978).

taposed and where the contacts had not been recognized before. The result is a clearer picture than had been obtained before of the relationship between the Navajo Sandstone and younger formations. Furthermore, our findings are consistent with the stratigraphic framework of Lower and Middle Jurassic strata as currently understood in other parts of the Western Interior of the United States.

Owing to stratigraphic complexities, some of the units cannot be discussed in a simple oldest-toyoungest fashion. On the following pages we describe the Navajo Sandstone as it occurs throughout the region, followed by descriptions of the Temple Cap and Carmel Formations in southwestern Utah, where the type localities of these two formations are located. We then discuss the Carmel and Page Formations in south-central and southeastern Utah and adjoining parts of Arizona, where these rocks are equivalent or nearly equivalent in age to the type Carmel of southwestern Utah. Following this is a brief description of the Entrada Sandstone, which lies on the Carmel throughout most of the region. Finally, we discuss the age of these formations in light of correlations to well-dated units in other regions and in light of recent paleontological discoveries.

The basic framework of this study consists of a network of 21 measured sections of the Temple Cap Sand- stone, about 100 complete or partial measured sections of the Carmel Formation, about 110 measured sections of the Page Sandstone, and 45 measured sections of the Entrada Sandstone. In addition, the logs from 13 drill holes were also used. This was supplemented by tracing the units laterally wherever possible, aided by the stratigraphic markers noted earlier, and by mapping in the Kaiparowits Plateau by W. E. Bowers, E. V. Stephens, H. A. Waldrop, H. D. Zeller, and Fred Peterson.

The writers acknowledge with gratitude the helpful comments and constructive criticism offered by W. E. Bowers, P. E. Soister, E. V. Stephens, H. A. Waldrop, and $H$. D. Zeller during the course of the Kaiparowits mapping project, which has been in progress since 1963. Other members of the U.S. Geological Survey who have given freely from their knowledge of the stratigraphy of the Triassic and Jurassic Systems of the United States include W. B. Cashion, L. C. Craig, M. W. Green, R. W. Imlay, R. B. O'Sullivan, C. E. Turner-Peterson, and D. G. Wyant. The palynomorphs were identified by Bruce Cornet of Gulf Research and Development Company, Houston, Texas, who has made extensive studies of the palynology of Upper Triassic and Lower Jurassic rocks of the eastern United States. Capable assistance in the field was given by B. E. Barnum, P. C. Birkhahn, J. D. Craig, C. 
J. Flynn, G. W. Horton, B. E. Law, R. A. Lehtola, O. L. Ligon, Jr., and R. L. Sutton.

Mapping was done in the Kaiparowits Plateau at the scale of $1: 24,000$ by plane table and alidade aided by aerial photos flown in 1951, 1958, and 1966. In the part of Glen Canyon now covered by Lake Powell, the study was augmented by photos in the files of the U.S. Geological Survey that were taken by T. H. O'Sullivan with the Wheeler Survey in the 1870's and by N. W. Bass, E. C. LaRue, H. D. Miser, and R. C. Moore with various U.S. Geological Survey parties in the 1920's. The sections were measured using a Brunton compass and steel tape or using an Abney level and 5-foot Jacob staff. Measurements were made in the English system and later converted to metric. Colors in the lithologic descriptions follow those in a rock color chart of Goddard and others (1963), but the number and letter code in that chart is not given because it implies a greater accuracy than is possible to achieve in the field. Bedding classification and terminology generally follow that of McKee and Weir (1953), and grain size is expressed in terms of the Modified Wentworth Grade Scale suggested by Dunbar and Rodgers (1957, p. 161). Sorting and mean grain size were estimated in the field with a hand lens, aided by comparison with 16 sieve analyses made by R. F. Gantnier on samples from the Page, Carmel, and Entrada Formations. In addition, 63 thin sections were prepared by M. E. Johnson from samples of each of the formations.

The term silty sandstone is used for moderately to poorly sorted very fine grained sandstone or coarse siltstone that is poorly to moderately cemented and generally weathers to form a slope. The term mudstone is used for a nonfissile or poorly fissile rock composed mainly of clay-size particles but also containing a significant fraction of silt and sand-size grains. Shale, while present, is for the most part included with the mudstone because it is minor, inconspicuous, and generally difficult to distinguish from the mudstone except at perfect exposures.

This report is a byproduct of a comprehensive program of the U.S. Geological Survey to evaluate and classify mineral lands in the public domain.

\section{GLEN CANYON GROUP}

The name Glen Canyon Group was first used by Baker and others (1927) for typical exposures in Glen Canyon, where it included, in ascending order, the Wingate Sandstone, rocks now known as the Kayenta Formation but at that time thought to be the Todilto Formation, and the Navajo Sandstone. Later, Williams (1954) named the Moenave Formation and assigned it to the group, where, in general, it is considered an equivalent to parts of the Wingate Sand- stone and Kayenta Formation (fig. 2). Previous workers considered the Glen Canyon Group Triassic and Jurassic in age and thought that the systemic boundary was near the top of the group, in the Navajo Sandstone. However, recent paleontological and stratigraphic discoveries, strongly suggest that the group is largely Early Jurassic in age and that the systemic boundary is at or near the base of the group, either at the base of the Lukachukai Member of the Wingate Sandstone or at the base of the Moenave Formation where the Lukachukai is absent. The Navajo Sandstone is the only formation in the group that is considered in detail here although a discussion of the age of the entire group is given in later paragraphs.

\section{NAVAJO SANDSTONE}

The Navajo Sandstone (Gregory, 1917) is a thick, cliff-forming, crossbedded sandstone formation that underlies a large part of southern Utah and northeastern Arizona. The colorful and spectacular sheer cliffs, deep canyons, and impressive spires, promontories, and monoliths that have been eroded in this formation are responsible for much of the scenic beauty of Zion National Park, Glen Canyon, and the Navajo Indian Reservation (figs. 3, 4). For the most part, the Navajo has two contrasting colors-various shades of red in the lower part and various shades of light gray in the upper part-but considerable variation occurs within these colors. The boundary between the red and white parts may be sharp or gradational, but in most places the color change bears little if any relation to bedding features and cuts directly across the stratification. In addition, one or the other of these colored zones may be missing, so that in places (for example, west of Zion Canyon) the formation is almost entirely moderate reddish orange or, as in parts of the Circle Cliffs area, it is entirely very light gray to very pale orange.

Most of the Navajo consists of quartzose sandstone that is well sorted and fine to medium grained, although at several places along the base of some of the crossbedding sets there are scattered well-rounded coarse and very coarse grains of quartz and black or gray chert. The principal bedding types are high-angle, large-scale crossbedding in tabular-planar, wedgeplanar, or trough-shaped sets generally 6-15 m thick, although one set $34 \mathrm{~m}$ thick was measured in Glen Canyon near the mouth of the San Juan River.

Minor but conspicuous lenses of interbedded sandstone, mudstone, and cherty limestone or dolomite (Pipiringos and O'Sullivan, 1975), comprise about 2-3 percent of the Navajo in south-central Utah and northcentral Arizona, but they are rare in southwestern Utah. The lenses contain fine-grained, moderately 


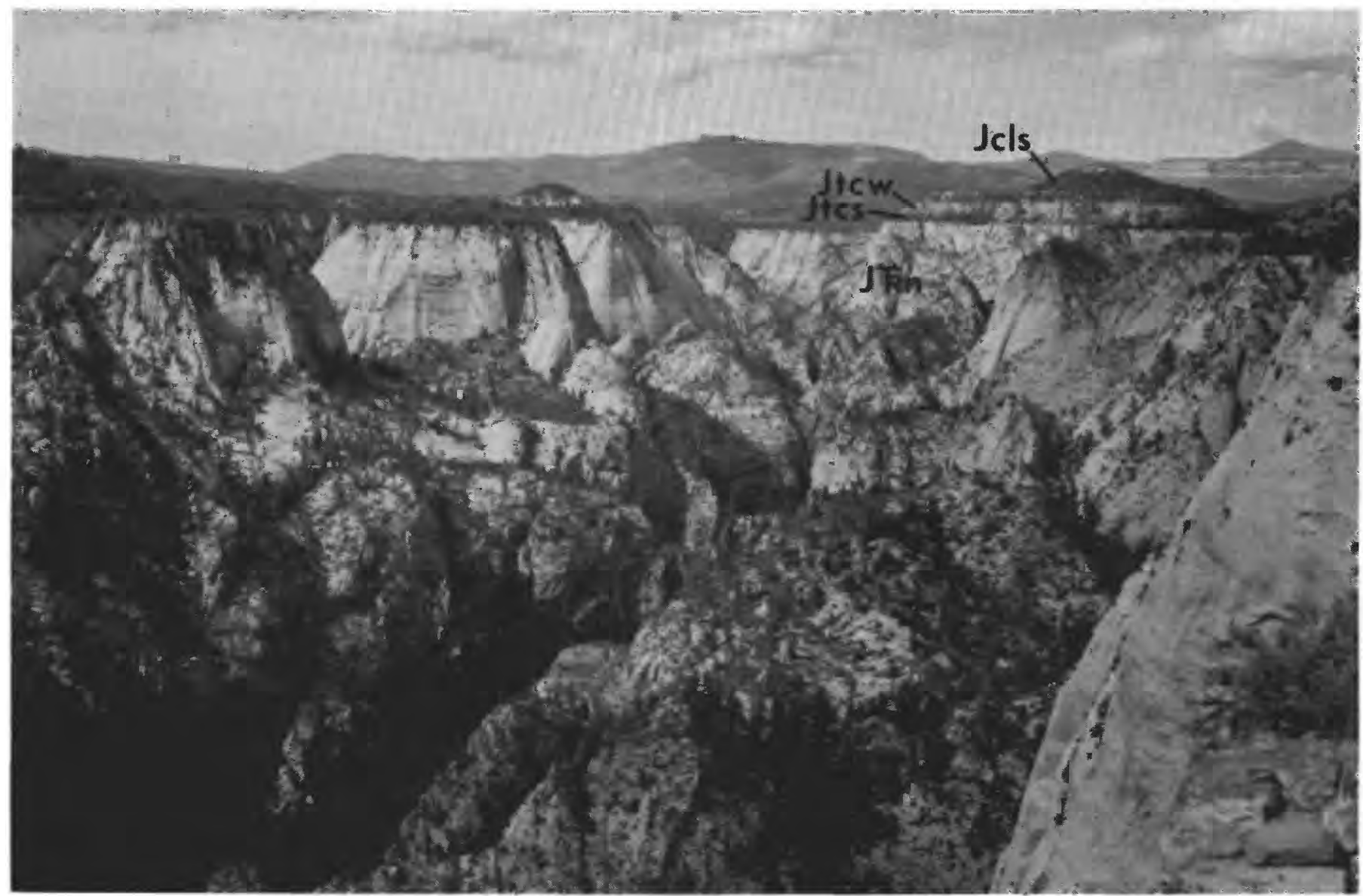

Figure 3.-View of typical exposures of the Navajo Sandstone ( $\mathrm{J} k \mathrm{n}$ ) and Temple Cap Sandstone in Zion Canyon, Utah. The narrow slotlike inner gorge of Zion Canyon is in the red lower part of the Navajo and the wider upper part of the canyon is in the white part of the Navajo. The red Sinawava Member of the Temple Cap (Jtcs) weathers to form a narrow, tree-covered shelf above the white cliffs of the Navajo and below the white crossbedded sandstone cliff of the White Throne Member of the Temple Cap (Jtcw). The limestone member of the Carmel Formation (Jcls) forms another tree-covered slope above the Temple Cap. The Temple Cap is about $52 \mathrm{~m}$ thick. View is northnorthwest from Observation Point in Zion National Park, Washington County, Utah.

sorted, laminated to very thin bedded, moderatereddish-brown to grayish-red-purple sandstone and silty sandstone interbedded with laminated dark-reddishbrown mudstone and light-gray cherty limestone or dolomite (fig. 5). Most of the lenses are less than $3 \mathrm{~m}$ thick and $300 \mathrm{~m}$ wide, although Davidson $(1967, \mathrm{p}$. 37) found several in the Circle Cliffs area that could be traced for $16-24 \mathrm{~km}$.

Although chert nodules are a minor constituent of the Navajo, they are especially significant because they were the most likely source of the chert pebbles that were incorporated in the basal part of some of the formations that lie on the Navajo. Two types of chert are present and both are of authigenic origin. Authigenic chert nodules in the limestone beds of the interbedded sandstone, mudstone, and limestone lenses are microcrystalline and range in color from medium gray to grayish red or pale brown. Most of these nodules are white or very light gray on the periphery (fig. 5). The other type of authigenic chert oc- curs as highly irregular masses as much as $0.3 \mathrm{~m}$ long that are present in the crossbedded sandstone, generally along the base of crossbedding sets or in some of the areas where slumping of the crossbedded sandstone occurred, as well as in the flat-bedded sandstone lenses that also contain thin limestone beds (fig. 6). For the most part, these irregular masses are color zoned from grayish red on the interior to white or very light gray on the outside, and the texture is either colloform or, less commonly, microcrystalline.

The greatest thickness of the Navajo known to the writers is $677 \mathrm{~m}$, measured in Zion National Park by Wilson (1965, p. 42). The formation thins eastward and is beveled out near the Arizona-New Mexico and UtahColorado State lines by the J-2 unconformity at the base of the overlying Middle Jurassic formations (fig. 2). The lower contact is sharp or gradational, and interfingering of the lower part with the Kayenta Formation has been recorded by Wilson (1965) in southwestern Utah and by Harshbarger, Repenning, 


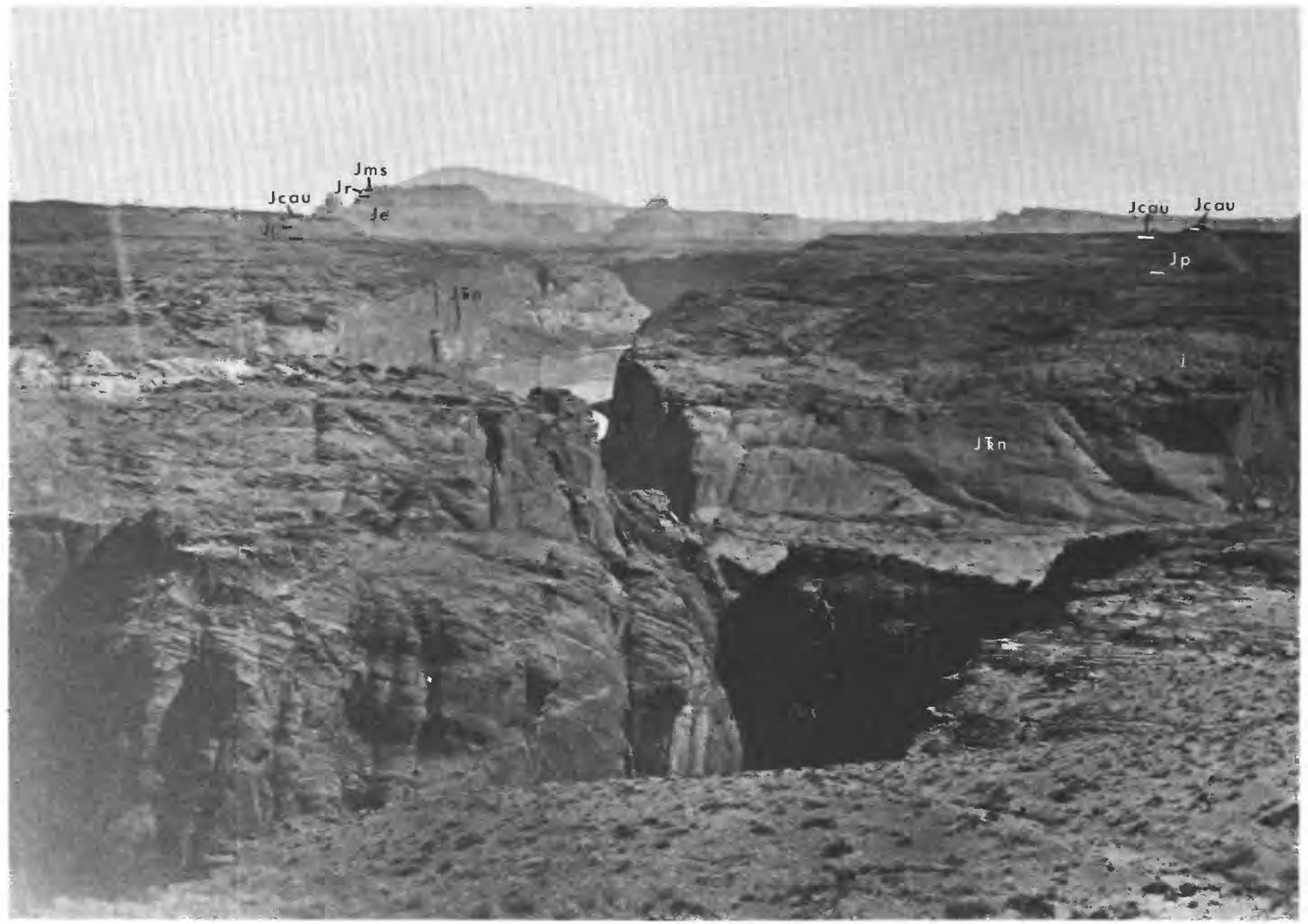

Figure 4.-View of typical exposures of red crossbedded Navajo Sandstone in Glen Canyon about $10 \mathrm{~km}$ northeast of Page, Ariz. In general, a bench is stripped back on top of the Navajo $(\mathrm{J} / \mathrm{n})$; this stripped bench is apparent on either side of the canyon at the foot of the smooth rounded bluffs of Page Sandstone (Jp). Some Holocene polygonal joint crevices (j) similar to fossil joint crevices preserved beneath the Page Sandstone (figs. 22, 23) are well exposed in the light-colored area to the right above the canyon walls. For scale, the Page Sandstone is about 38 and $46 \mathrm{~m}$ thick, respectively, on the right and left sides of the canyon, which is about $134 \mathrm{~m}$ deep in the middle of the photo. Warm Creek Canyon in foreground, Navajo Mountain forms the broad asymmetrical dome on the skyline. Jcau, upper member of Carmel Formation; Je, Entrada Sandstone; Jr, sandstone at Romana Mesa; Jms, Salt Wash Member of Morrison Formation. View is toward east in the NE $1 / 4$ sec. 12, T. 44 S., R. 4 E., Kane County, Utah. Photo by T. H. O'Sullivan (Wheeler Survey), 1873.

and Irwin (1957) in southeastern Utah and northeastern Arizona.

\section{SAN RAFAEL GROUP}

The San Rafael Group was named by Gilluly and Reeside (1928, p. 73) for strata in the San Rafael Swell of Central Utah that include, in ascending order, the Carmel, Entrada, Curtis, and Summerville Formations. Later workers added the Todilto Limestone and Bluff Sandstone to the group (Harshbarger and others, 1957, p. 32). The Todilto and Bluff are present near the Four Corners and farther south, but they are not described in this report. Two additional formations, the Temple Cap Sandstone (formerly a member of the Navajo Sandstone) and the Page Sandstone (formerly an unnamed part of the Navajo), are also assigned to the San Rafael Group in this report. Along with the Carmel Formation, these are the only formations in the group that are considered in detail here. Paleontological evidence and regional stratigraphic relations indicate that the group is Middle Jurassic in age (R. W. Imlay, oral commun., 1976).

\section{TEMPLE CAP SANDSTONE}

The Temple Cap Sandstone is presently known to occur only in southwestern Utah, where it forms a distinct stratigraphic unit between the Navajo Sandstone and the Carmel Formation (fig. 3). The formation was considered an informal member of the Carmel by Baker, Dane, and Reeside (1936, p. 22). It was con- 


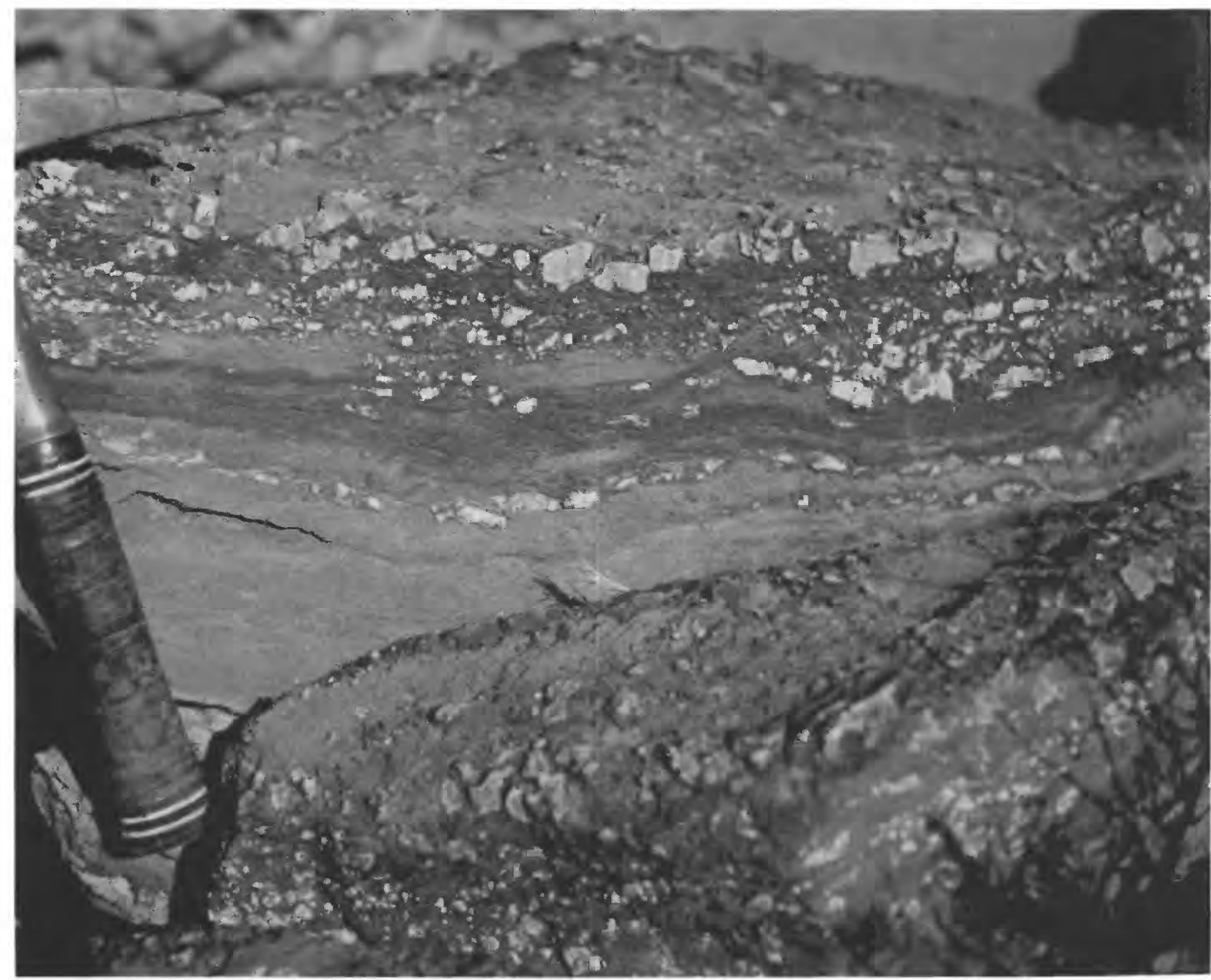

FIGURE 5.-Authigenic chert nodules in limestone bed of Navajo Sandstone. Several of the nodules are color zoned from medium gray or grayish red in the middle to very light gray or white on the periphery. Weathering of beds such as this probably produced many of the detrital chert pebbles that were incorporated in the basal stratum of the Page Sandstone. East side of Dangling Rope Canyon about 6.4 km southwest of Navajo Point, Kane County, Utah.

sidered a formal member of the Navajo Sandstone by Grater (1948) and later a more detailed description was published by Gregory (1950a, p. 89). Workers since 1961 (Lewis and others, 1961) thought that the Temple Cap graded into the Navajo east of Mount Carmel Junction, Utah, but recent field examination of that area indicates that these formations do not intergrade. Because the Temple Cap is a separate mappable unit that can be distinguished from the Navajo and Carmel Formations, and because the Temple Cap is more closely related temporally, and to some extent lithologically, to other formations in the San Rafael Group, the Temple Cap is here raised to formation rank, removed from the Glen Canyon Group, and included in the San Rafael Group.

The type locality of the Temple Cap (Gregory, 1950a, p. 89) is at the top of East and West Temples in Zion National Park, where the formation is only accessible by means of mountaineering techniques or with a helicopter. For this reason, a more accessible section measured about $500 \mathrm{~m}$ northeast of Observation Point, at the top of Zion Canyon (fig. 7), is here proposed as a principal reference section. This section also serves as the type section of two new members that are here named the Sinawava Member and the White Throne Member. The principal reference section is typical of 


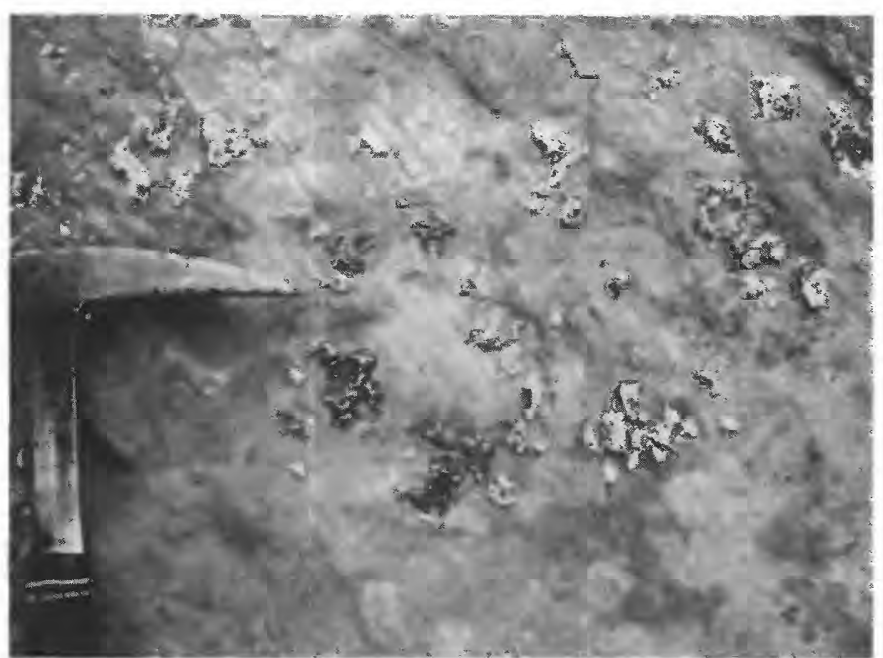

Figure 6.-Authigenic chert in sandstone bed of Navajo Sandstone. Although these nodules and small blebs are in a flat-bedded sandstone lens, similar but larger nodules also occur in the crossbedded sandstone of the Navajo. Note the extreme angularity and the tiny fingers that extend from the nodules out into the sandstone. West side of West Canyon tributary to Glen Canyon about $4 \mathrm{~km}$ southeast of Gregory Butte in the SW1/4 sec. 23, T. 43 S., R. $6 \frac{1}{2}$ E., San Juan County, Utah.

the formation in the Zion Canyon section of Zion National Park and farther east. West of Zion Canyon the White Throne Member grades into a predominantly flat bedded redbed facies that is included in the Sinawava Member.

The Temple Cap thins irregularly eastward along the principal line of outcrops from a maximum of $113.4 \mathrm{~m}$ near Gunlock, Utah, to its wedgeout near Johnson Canyon (fig. 8).

\section{SINAWAVA MEMBER}

The Sinawava (pronounced Si-na'-wa-va, meaning Wolf-god in the Paiute language according to Woodbury, 1950, p. 112) Member of the Temple Cap Sandstone takes its name from the Temple of Sinawava in Zion Canyon (Gregory, 1950a, fig. 98) about $1 \mathrm{~km}$ northwest of the type section, which is $500 \mathrm{~m}$ northeast of Observation Point (fig. 7). At the type section and throughout the area east of the Hurricane Cliffs, the member is a slope-forming unit composed of interbedded sandstone, silty sandstone, and mudstone. West of the Hurricane Cliffs, the topographic character and lithologic composition remain the same but several beds of gypsum are also present. West of Mount Carmel Junction the Sinawava is moderate reddish brown to dark reddish brown and it forms a conspicuous dark-red slope between the lighter colored cliffs of the underlying Navajo Sandstone and the overlying White Throne Member of the Temple Cap. East of Mount Carmel Junction the Sinawava grades to very light gray or very pale orange and the color difference between the overlying and underlying rocks is not as conspicuous. Here, the member must be recognized and traced solely on the basis of its slopeforming character and lithologic composition.

The Sinawava Member thins irregularly eastward from $6.1 \mathrm{~m}$ at the type section near Observation Point to $2.4 \mathrm{~m}$ at Johnson Canyon about $27 \mathrm{~km}$ east of Mount Carmel Junction, where it is overlain by the thin wedge edge of the White Throne Member (fig. 9). East of Johnson Canyon the Sinawava apparently is truncated by the J-2 unconformity at the base of the overlying Carmel Formation (fig. 8), but this area is heavily covered by soil, windblown sand, and vegetation; and the relationships at the wedgeout of the Sinawava could not be examined. West of the type section, near Observation Point, the Sinawava thickens irregularly to as much as $113.4 \mathrm{~m}$, owing primarily to interfingering and westward replacement of beds in the White Throne Member, as shown in figure 8. As a result of this facies change, the White Throne is missing west of the Hurricane Cliffs, and the Sinawava is the only member of the Temple Cap that is present.

The Sinawava Member consists of interbedded slope-forming sandstone, silty sandstone, mudstone, and scarce gypsum. The sandstone and silty sandstone beds are very fine to fine grained, poorly to moderately sorted, and are predominantly moderate reddish brown, although several beds are light gray to very light gray. Scattered throughout several of these beds are well-rounded coarse and very coarse grains or very fine pebbles of black, gray, light-brown, green, orange, or red chert. The scattered coarse grains and small pebbles are fairly common in the western part of the Sinawava; they were found as far east as section 9 at Potato Hollow, which is about $7.2 \mathrm{~km}$ northwest of the type section above Zion Canyon. At Cottonwood Canyon (sec. 7, fig. 8), scattered angular light-gray chert pebbles up to $13 \mathrm{~mm}$ long are locally present in a thin sandstone bed at the base of the member. The chert is similar to the authigenic chert that occurs in nodules in the underlying Navajo Sandstone. Mudstone in the member is laminated to very thin bedded and dark reddish brown or yellowish gray. Very light gray gypsum is also present west of the Hurricane Cliffs, where it occurs in several beds as much as $2 \mathrm{~m}$ thick that are laminated to very thin bedded or composed of nodular gypsum aggregates. As many as eight thin beds of very dusky purple or yellowish-gray bentonite as much as $0.6 \mathrm{~m}$ thick occur in the middle of the member west of the Hurricane Cliffs.

The basal contact of the Sinawava, named the J-1 surface by Pipiringos and O'Sullivan (1978), is a clearly defined and continuous surface that is easy to recognize because it separates markedly different 


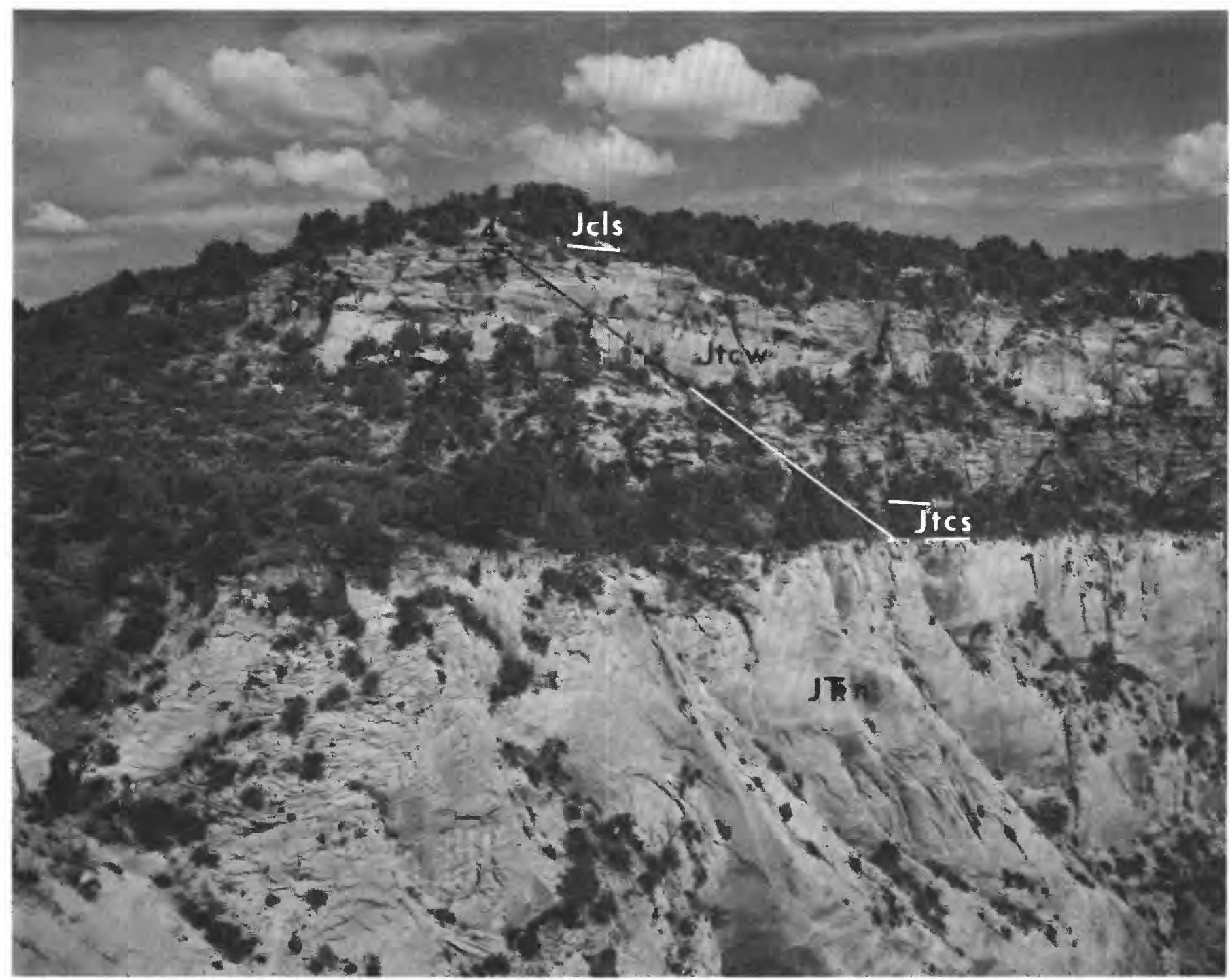

FIGURE 7.-Principal reference section of Temple Cap Sandstone and type section of the Sinawava and White Throne Members above Zion Canyon, Utah. 4, principal reference section, Temple Cap Sandstone is $55.8 \mathrm{~m}$ thick; (J K $\mathrm{n}$ ), Navajo Sandstone; Jtcs, Sinawava Member of Temple Cap Sandstone; Jtcw, White Throne Member of Temple Cap; Jcls, limestone member of Carmel Formation. View is toward the northeast from Observation Point in Zion National Park.

lithologies. The abrupt change in rock types at this contact, the lateral continuity of this surface, the broad irregular form of this surface with respect to the upper contact of the Temple Cap (fig. 8), the local presence of small angular chert pebbles on it that probably were derived from the underlying Navajo Sandstone, and the extensive bleaching at the top of the underlying Navajo Sandstone east of Zion Canyon, suggest that the J-1 surface at the base of the Sinawava is an unconformity. However, none of these features can be considered as conclusive evidence that the J-1 surface is indeed an unconformity, and it could also be that this surface merely marks an abrupt and widespread change in depositional environments.

\section{WHITE THRONE MEMBER}

The White Throne Member takes its name from the Great White Throne in Zion Canyon, which is about 2 $\mathrm{km}$ south of the type section about 500 m northeast of Observation Point (fig. 7). The member is a conspicuous cliff-forming unit (fig. 3) composed of finegrained well-sorted crossbedded sandstone. The crossbedding is the high-angle tabular-planar or wedge-planar type in sets as much as $6 \mathrm{~m}$ in thickness. Locally, the sandstone contains small irregular blebs less than $1 \mathrm{~cm}$ wide of very light gray authigenic chert along the base of some of the crossbedding sets. At the type section in Zion Canyon and farther east, the member is very light gray to very pale orange, but 


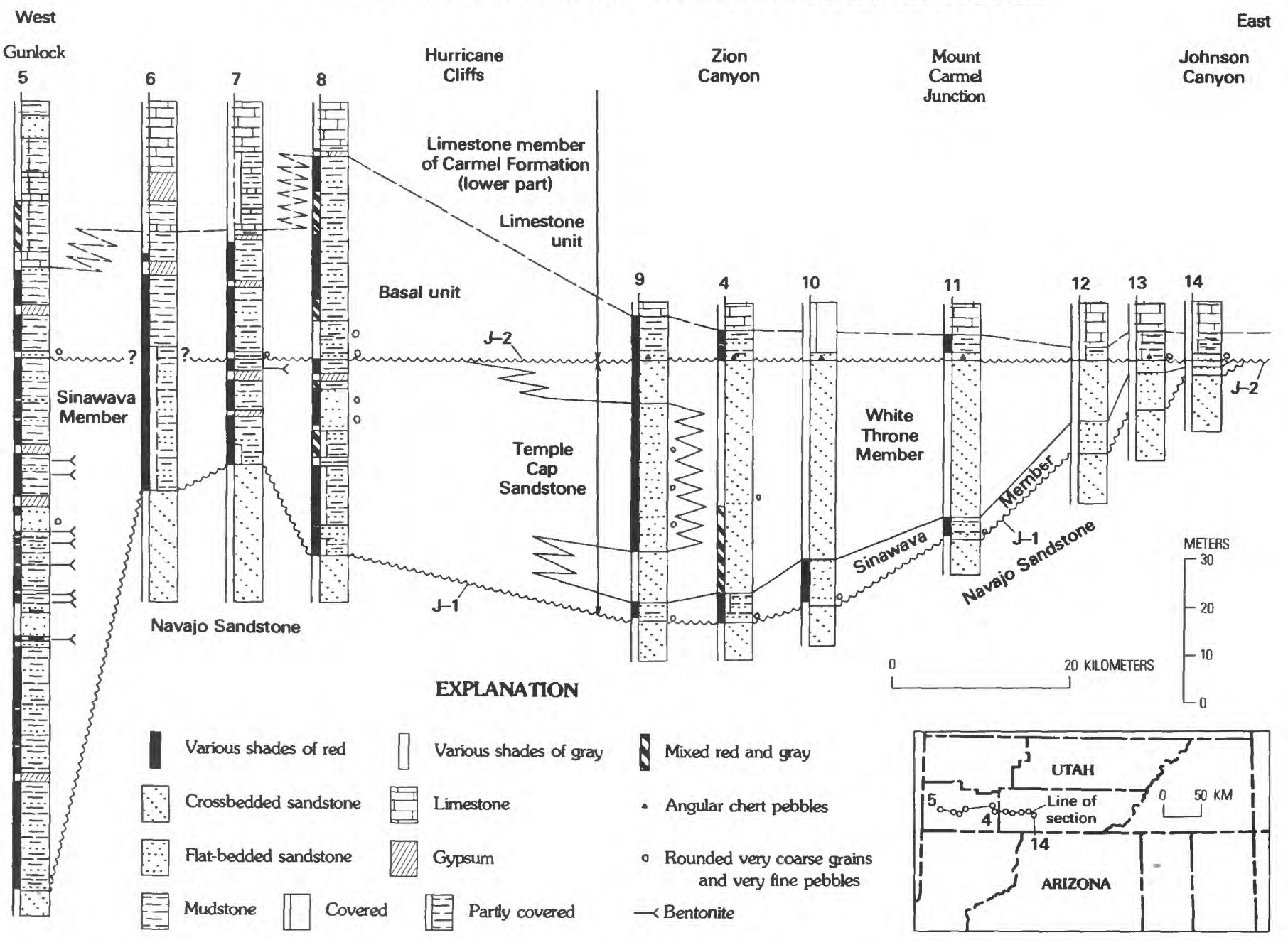

FIGURE 8. - Stratigraphic section from Gunlock to Johnson Canyon, Utah, showing relations of Temple Cap Sandstone to Navajo Sandstone and Carmel Formation. Unconformity shown by wavy line. J-1, J-2, unconformities of Pipiringos and O'Sullivan (1978).

west of Zion Canyon the color grades to moderate reddish orange. The White Throne is $49.7 \mathrm{~m}$ thick at the type section, and it thins eastward to Johnson Canyon (figs. 8, 9), where it is beveled out by the J-2 unconformity at the base of the overlying Carmel Formation. West of Zion Canyon the White Throne grades into the Sinawava Member (fig. 8).

East of Mount Carmel Junction the lower contact generally is well exposed and it is a fairly sharp and planar surface (fig. 9). West of Mount Carmel Junction the contact generally is poorly exposed, but in the few places where it is visible it is vertically gradational through a thin transition zone about $1 \mathrm{~m}$ thick that consists of laminated to very thin bedded and small- to medium-scale crossbedded sandstone.

Probably because of similar lithologic characteristics, many workers thought that the crossbedded sandstone of the White Throne Member was a tongue of the Navajo Sandstone that merged with that formation just east of Mount Carmel Junction (Lewis and others, 1961, p. 1439; Wright and Dickey, 1963a, p. E65, and 1963b; Wilson, 1965, p. 42; Thompson and Stokes, 1970, p. 6). However, the flatbedded Sinawava Member does not pinch out and the crossbedded White Throne Member does not merge with the crossbedded Navajo anywhere east of Mount Carmel Junction. Instead, the Sinawava continues on east to Johnson Canyon where the stratigraphic relations indicate that the entire Temple Cap Sandstone is beveled out (figs. 8, 10). Thus, the White Throne Member is an eastward-thinning wedge, separated from the Navajo Sandstone by the Sinawava Member, and does not merge with the Navajo Sandstone.

\section{CARMEL FORMATION}

The Carmel Formation (Gregory and Moore, 1931; Cashion, 1967) is a generally eastward thinning limestone, gypsum, and redbed unit that is present 


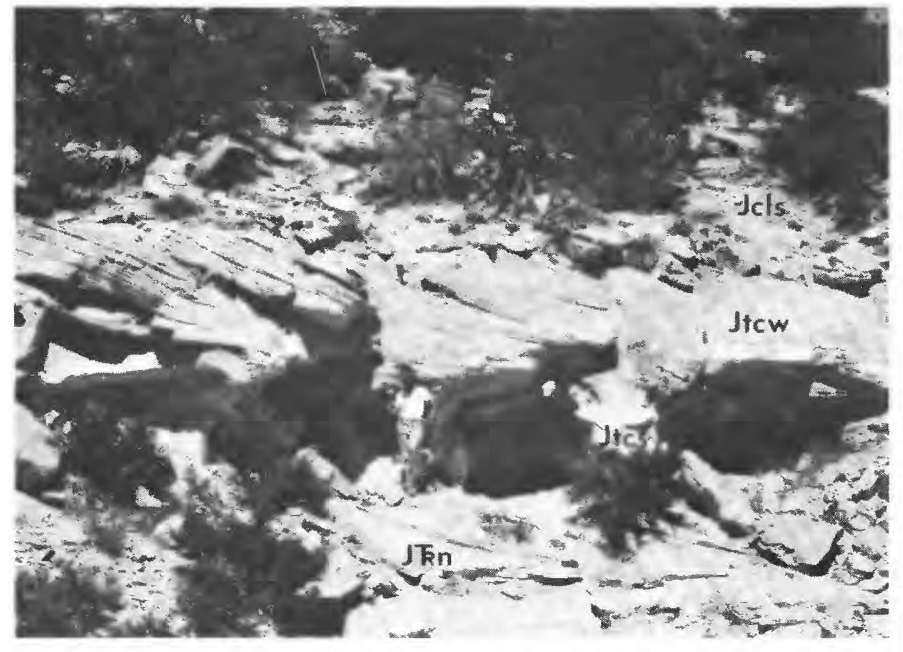

FIgure 9.-Thin Temple Cap Sandstone at Johnson Canyon about $27 \mathrm{~km}$ east of Mount Carmel Junction, Utah. The flat-bedded Sinawava Member (Jtcs) forms a notch beneath the crossbedded White Throne Member (JtcW), which forms a conspicuous ledge beneath the rubble-covered slopes of the limestone member of the Carmel Formation (Jcls). The Temple Cap is $3.7 \mathrm{~m}$ thick here. J $\mathrm{n}$, Navajo Sandstone. West side of Johnson Canyon in the NW $1 / 4$ sec. 26, T. 41 S., R. 5 W., Kane County, Utah.

throughout southern Utah and northeastern Arizona. At the type locality near Mount Carmel Junction, Utah, the formation consists of four members, which are (from oldest to youngest) the limestone member, banded member, gypsiferous member, and Winsor Member. A somewhat different nomenclature is used farther east in south-central Utah, where several significant facies or nomenclatural changes occur: the limestone member is termed the Judd Hollow Tongue of the Carmel east of Cannonville, Utah, and the Judd Hollow grades farther east into the Page Sandstone; the banded member grades eastward into the Thousand Pockets Tongue of the Page Sandstone; the gypsiferous member grades into the lowest part of the upper member of the Carmel; and the Winsor Member grades into the middle and upper parts of the upper member of the Carmel.

\section{LIMESTONE MEMBER}

The limestone member of the Carmel Formation (Cashion, 1967) is composed of two units: a lower, thin, slope-forming mudstone and sandstone unit and an upper, thick, cliff-and-slope-forming limestone and shale unit (fig. 13). At the type locality of the Carmel near Mount Carmel Junction, the lower unit is about $5.5 \mathrm{~m}$ thick and consists of moderate-reddish-brown, very light gray, or very pale orange, very fine to finegrained, poorly to moderately sorted sandstone and silty sandstone interbedded with laminated to very thin bedded mudstone or shale. Locally scattered along the base are coarse and very coarse grains or very fine peb- bles of chert and green mudstone pellets or chips. The upper unit is $66.1 \mathrm{~m}$ thick and contains very light gray to very pale orange, laminated to thin-bedded, microcrystalline to fine-grained, fossiliferous limestone interbedded in the middle with yellowishgray calcareous shale and scarce moderate-reddishbrown mudstone. Several beds of light-olive-gray oolitic limestone commonly occur in about the lower third of the upper unit. About $11 \mathrm{~km}$ southwest of Cannonville, Utah, the middle part of the upper unit contains as many as four beds of light-gray gypsum as much as $0.3 \mathrm{~m}$ thick.

The limestone member is $71.6 \mathrm{~m}$ thick at the type locality of the Carmel near Mount Carmel Junction and it thickens westward to $191.1 \mathrm{~m}$ near Danish Ranch in southwestern Utah (sec. 8, fig. 10). It thins eastward to $34.4 \mathrm{~m}$ at the Paria River near Cannonville, where rocks equivalent to this member are termed the Judd Hollow Tongue of the Carmel Formation.

The lower contact is described with the lower contact of the Judd Hollow Tongue.

\section{JUDD HOLLOW TONGUE}

East of the Paria River near Cannonville, Utah, strata equivalent to the limestone member have been named the Judd Hollow Tongue of the Carmel Formation (Phoenix, 1963, p. 33). The Judd Hollow is $34.4 \mathrm{~m}$ thick near Cannonville (sec. 20, fig. 10), where it consists of essentially the same lithologies as the limestone member farther west; but east of the Paria River the limestone beds thin and pinch out into laminated to thin-bedded, moderate-reddish-brown sandstone, silty sandstone, and mudstone (Wright and Dickey, 1963a, p. E66). Although the upper $0.3 \mathrm{~m}$ of the Judd Hollow at the Paria River near Cannonville consists of red mudstone that correlates with the lowermost part of the banded member farther west, by far the greater part of the Judd Hollow correlates with the limestone member. For all practical purposes, one may consider the Judd Hollow the eastern equivalent of the limestone member.

The Judd Hollow Tongue is about $9.9 \mathrm{~m}$ thick at the type locality in Judd Hollow on the south side of the Kaiparowits Plateau about $27 \mathrm{~km}$ northwest of Page, Ariz. (fig. 10, sec. 26). Here, it consists mainly of sandstone and siltstone, although it also contains one thin bed of silty limestone about $0.3 \mathrm{~m}$ thick (Phoenix, 1963 , p. 69 , sec. 3, unit 3). Several kilometers southeast of this locality these beds grade into crossbedded sandstone strata that are included in the Page Sandstone (fig. 10). A similar facies change occurs on the north side of the Kaiparowits Plateau about $34 \mathrm{~km}$ southeast of Escalante, Utah (fig. 11).

The lower contact of the limestone member is a sharply defined, continuous and planar surface that 


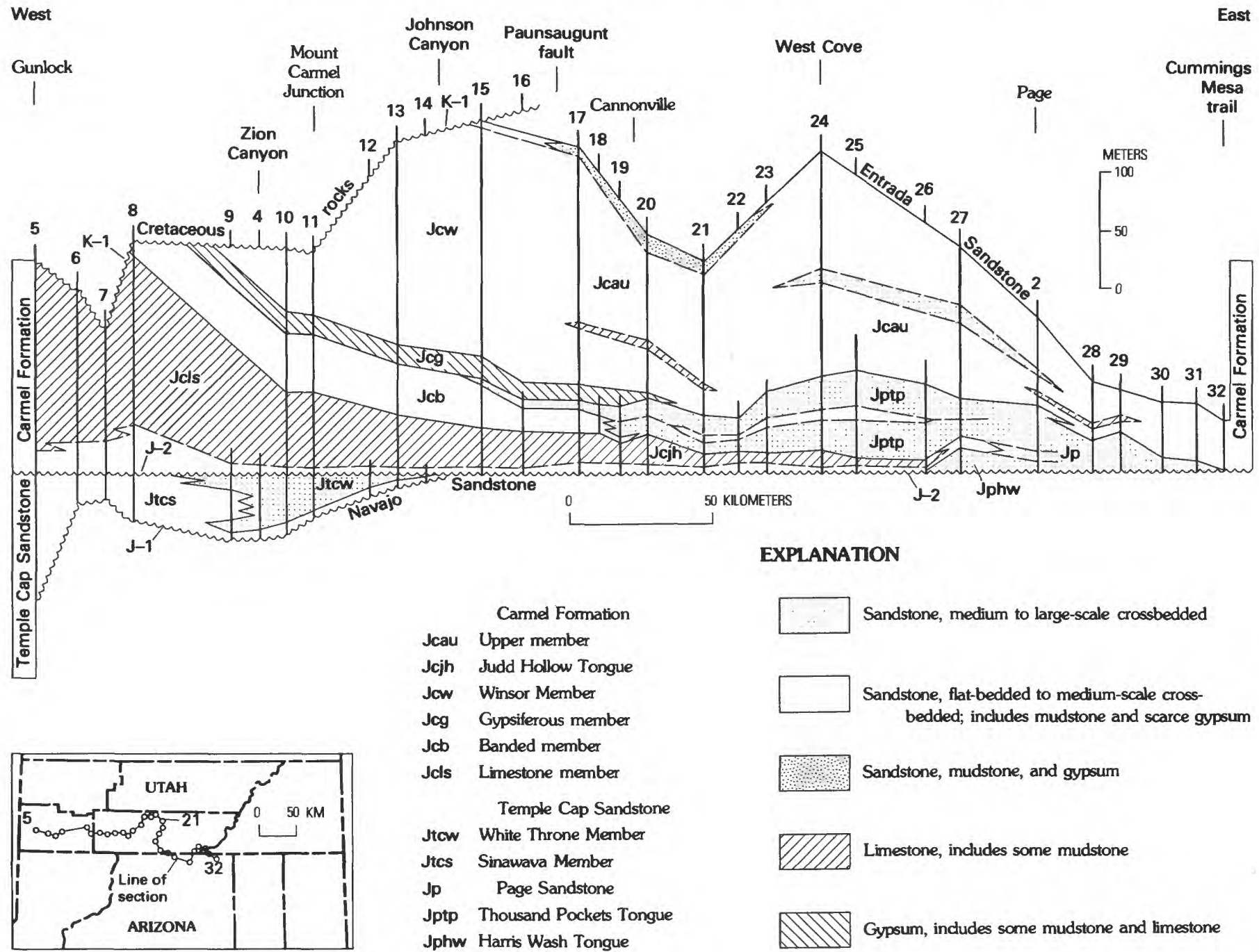

FIGURE 10.-Restored section from Gunlock, Utah, to Cummings Mesa, Ariz., showing correlations and dominant lithologies in the Temple Cap, Carmel, and Page Formations. Unconformity shown by wavy line, J-1, J-2, K-1, unconformities of Pipiringos and O'Sullivan (1978). Dashed lines indicate correlation of beds or minor units below member rank.

bevels out the Temple Cap Sandstone in southwestern Utah (figs. 8, 10). This surface is named the J-2 unconformity by Pipiringos and O'Sullivan (1978). The contact is marked by local concentrations of whatever hard and resistant coarser grains and small pebbles or authigenic chert blebs and nodules are present in the underlying rocks. Where the limestone member lies on the White Throne Member of the Temple Cap Sandstone, or where the limestone member and Judd Hollow Tongue lie on the Navajo Sandstone, the lowest bed of the limestone member or Judd Hollow Tongue contains scattered or locally concentrated coarse and very coarse grains and very fine pebbles of subangular to angular, very pale orange, grayish-pink, or very light gray chert that probably were derived from authigenic chert blebs or nodules in the underlying rocks. Where underlain by the Sinawava Member of the Temple Cap Sandstone in southwestern Utah, the lowest bed of the limestone member contains scattered or locally concentrated coarse and very coarse grains and very fine pebbles of well-rounded, red, black, light-gray, light-brown, green, or orange chert. Evidently the coarser grains and small pebbles were derived from the eroded parts of the underlying formations and locally concentrated in lag deposits during the earliest stage of deposition of the limestone member or Judd Hollow Tongue. Where the Judd Hollow rests on the Harris Wash Tongue of the Page Sandstone, the contact is conformable and either sharp and planar or vertically gradational through a transition zone about $1 \mathrm{~m}$ thick of laminated to very thin bedded or small- to medium-scale crossbedded sandstone. Angular chert pebbles were not found at the contact with the Harris Wash Tongue, although local- 


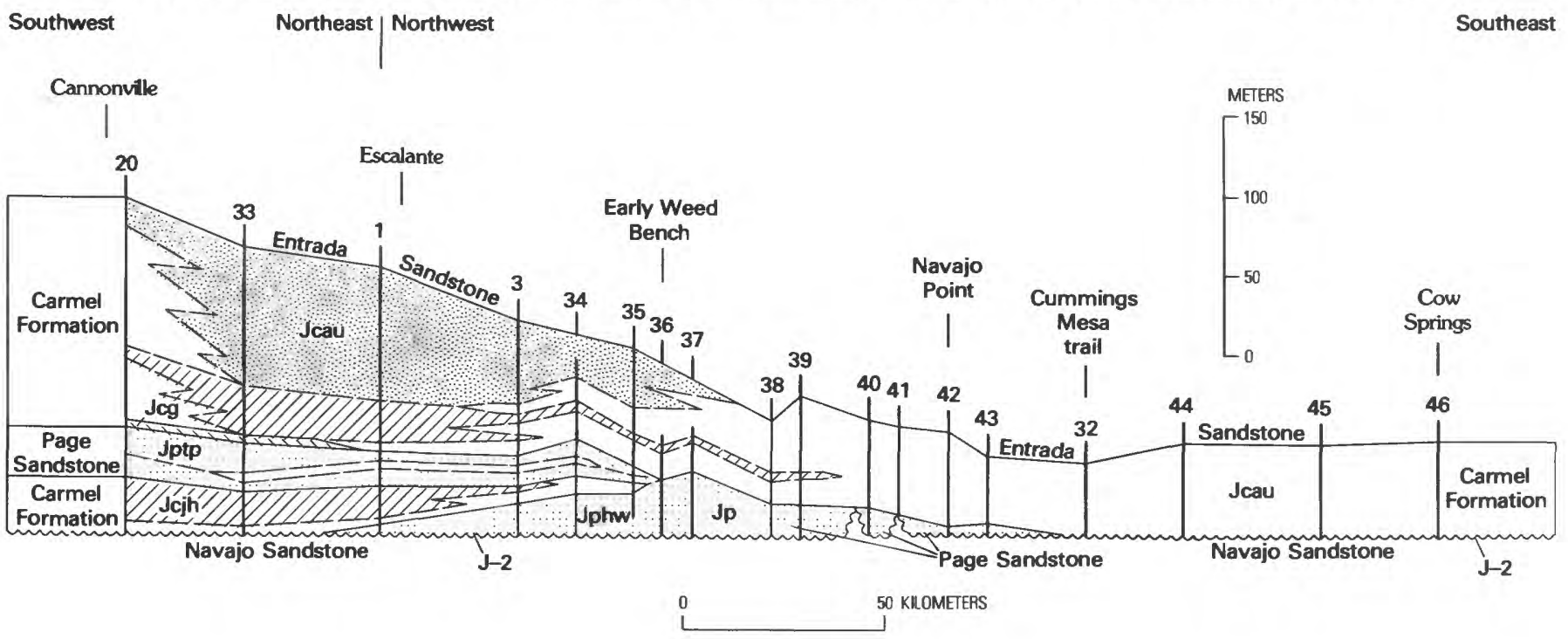

\section{EXPLANATION}

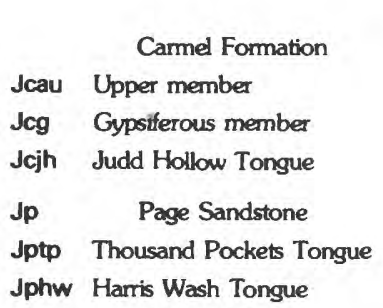

FIGURE 11.-Restored section from Kodachrome Flat near Cannonville, Utah, to Cow Springs, Ariz., showing correlations and dominant lithologies in the Page Sandstone and Carmel Formation. Unconformity shown by wavy line. J-2, unconformity named by Pipiringos and O'Sullivan (1978). Dashed lines indicate correlation of beds or minor units below member rank.

ly, as at measured section 27 in Sand Valley, coarse and very coarse sand grains are scattered in the basal stratum of the Judd Hollow just above the Harris Wash Tongue.

\section{BANDED MEMBER}

The banded member of the Carmel Formation (Cashion, 1967) is a slope-forming sandstone unit that was mistaken for the Entrada Sandstone by early workers (Baker and others, 1936; Gregory, 1948, $1950 \mathrm{a}, \mathrm{b})$ and later shown to be part of the Carmel Formation by Wright and Dickey $(1963 a, b)$. At the type locality of the Carmel, near Mount Carmel Junction, it is composed of very fine to fine-grained, poorly to moderately sorted, moderate-reddish-brown, light-red, and very light gray sandstone (fig. 12).

The stratification is very thin to thin bedded and small to medium scale, low and high angle, tabular planar crossbedded in sets less than a meter thick. Scattered well-rounded pebbles of chert, quartzite, tuffaceous sandstone, and microcrystalline or porphyritic igneous rocks as much as $1.5 \mathrm{~cm}$ long locally occur in the member. West of Mount Carmel Junction, Gregory (1950b, p. 89) noted that the member contains two beds of white gypsum $0.3 \mathrm{~m}$ thick and a bed of conglomerate $3 \mathrm{~m}$ thick composed of chert and quartzite pebbles as much as $2.5 \mathrm{~cm}$ in diameter. About $11 \mathrm{~km}$ southwest of Cannonville, Utah, a bed of light-gray gypsum, $7.3 \mathrm{~m}$ thick, is present at the base of the member.

In general, the banded member thins southeastward across southwestern Utah. It is as much as $68.3 \mathrm{~m}$ thick about $30 \mathrm{~km}$ northwest of Mount Carmel Junction (Gregory, $1950 \mathrm{~b}$, p. 89) and is $51.2 \mathrm{~m}$ thick at Mount Carmel Junction (Gregory, 1950a, p. 127; Cashion, 1967, p. J3). In the outcrop belt between Johnson Canyon and Cannonville, Utah, the member grades laterally into the Thousand Pockets Tongue of the Page Sandstone. Contrary to Thompson and Stokes (1970, p. 6), we could not find evidence of a regional unconformity between the banded member (their Crystal Creek Member) and the Thousand Pockets Tongue. The best place where interfingering of these units can be examined is in the canyon of Willis 


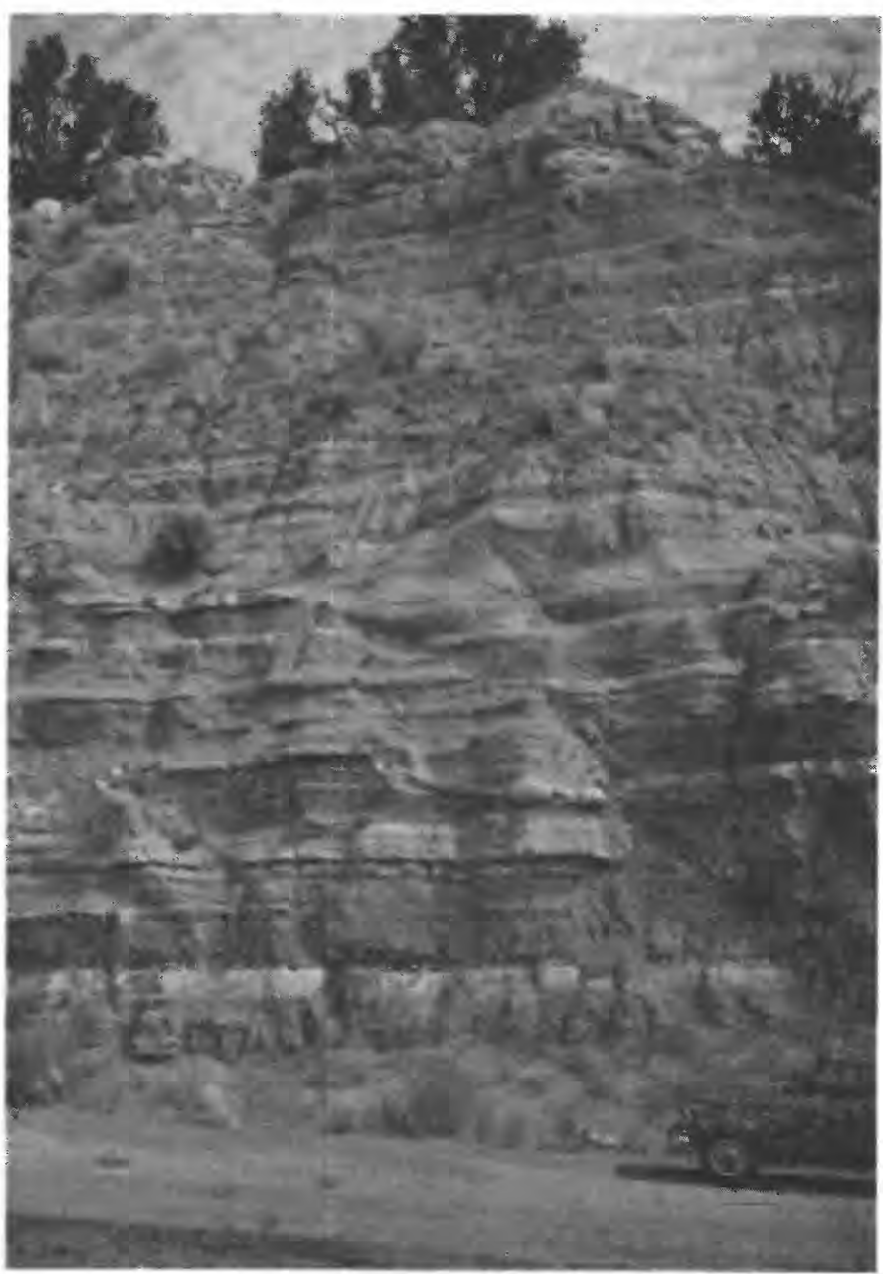

FiguRE 12.-Good exposures of banded member of Carmel Forma. tion near Mount Carmel Junction, Utah. The member consists of interbedded red to white, flat-bedded and crossbedded sandstone and silty sandstone and red mudstone that locally contains sandstone-filled mudcracks. Uppermost rounded gray ledge is basal part of gypsiferous member of Carmel Formation. View is northeast about $0.5 \mathrm{~km}$ northwest of Mount Carmel Junction, Kane County, Utah.

Creek about $10 \mathrm{~km}$ southwest of Cannonville, Utah (fig. 13).

The lower contact of the banded member is a sharp and planar surface at the top of the highest limestone bed of the limestone member. Some interfingering of the lowest beds of the banded member and the highest beds of the limestone member may occur in the area west of the Paria River near Cannonville, but the exposures are too poor to determine this accurately.

GYPSIFEROUS MEMBER

The gypsiferous member of the Carmel Formation (Cashion, 1967) tends to form cliffs where exposed to rapid erosional processes (fig. 14), but for the most part it forms a slope that is covered by soil and vegetation.
At the type locality of the Carmel and at many other places, the lower half or two-thirds of the member consists of white to very light gray gypsum that is laminated to thin bedded or is composed of nodular gypsum aggregates. One or two thin beds of light-gray limestone or yellowish-gray mudstone also occur locally in this part of the member, although they are not common. In places, the basal $0.3-1.0 \mathrm{~m}$ - consists of light-olive-gray to yellowish-gray mudstone that locally contains mudchip conglomerate composed of fragments $2-5 \mathrm{~cm}$ long of mudstone similar to that in the underlying banded member. The upper half or third of the gypsiferous member contains light-gray, yellowish-gray, or moderate-reddish-brown, laminated to thin-bedded, gypsiferous sandstone, silty sandstone, or mudstone, and pale-olive to light-gray, laminated, locally fossiliferous limestone. It was once thought that the member correlated with the Curtis Formation of central Utah (Gregory, 1950a, b, 1951) but later, Wright and Dickey (1963a) demonstrated that it is older than the Curtis.

The gypsiferous member is $15.2 \mathrm{~m}$ thick at Mount Carmel Junction and it thickens irregularly westward to as much as $41.8 \mathrm{~m}$ near Kanarraville, Utah, about 50 $\mathrm{km}$ northwest of Mount Carmel Junction (Gregory, 1950 b, p. 85). It has not been found or reported west of the Hurricane Cliffs, where, presumably, it was removed by erosion prior to deposition of Cretaceous rocks. The member thins eastward, largely by interfingering with the lower beds of the upper member of the Carmel, and pinches out about $11 \mathrm{~km}$ southeast of Cannonville, Utah, and near Escalante, Utah (figs. 10, 11).

The lower contact is sharp and generally planar, although several centimeters of relief occur on the surface in places. The contact was chosen at the base of the lowest gypsum, limestone, or mudchip conglomerate bed in the gypsiferous member. Although the local mudchip conglomerate at the base suggests an unconformity, we could find no evidence that any appreciable regional erosion or nondeposition occurred prior to deposition of the member. About $15 \mathrm{~km}$ northeast of Page, Ariz., interfingering occurs along the lateral continuation of this surface between the Page Sandstone and the overlying upper member of the Carmel Formation (fig. 10). Elsewhere in the Western Interior, Imlay $(1967$, p. 20,45$)$ found evidence of erosion at about the same stratigraphic position at the base of the Watton Canyon Member of the Twin Creek Limestone.

\section{WINSOR MEMBER}

The Winsor originally was considered a separate formation at the top of the Jurassic System in southwestern Utah by Gregory (1950a, b). Later, Wright and Dickey (1963a, b), who did not use the term 
Winsor, included these rocks in the Carmel and correlated them with strata farther east and northeast in south-central Utah that long had been considered part of the Carmel Formation. Based on the correlations established by Wright and Dickey, Cashion (1967) reviewed the nomenclature of the Carmel Formation, reduced the Winsor to member rank, and included it as the youngest member in the Carmel Formation west of the Paunsaugunt fault, which is about $50 \mathrm{~km}$ northeast of Mount Carmel Junction (fig. 10). Cashion's

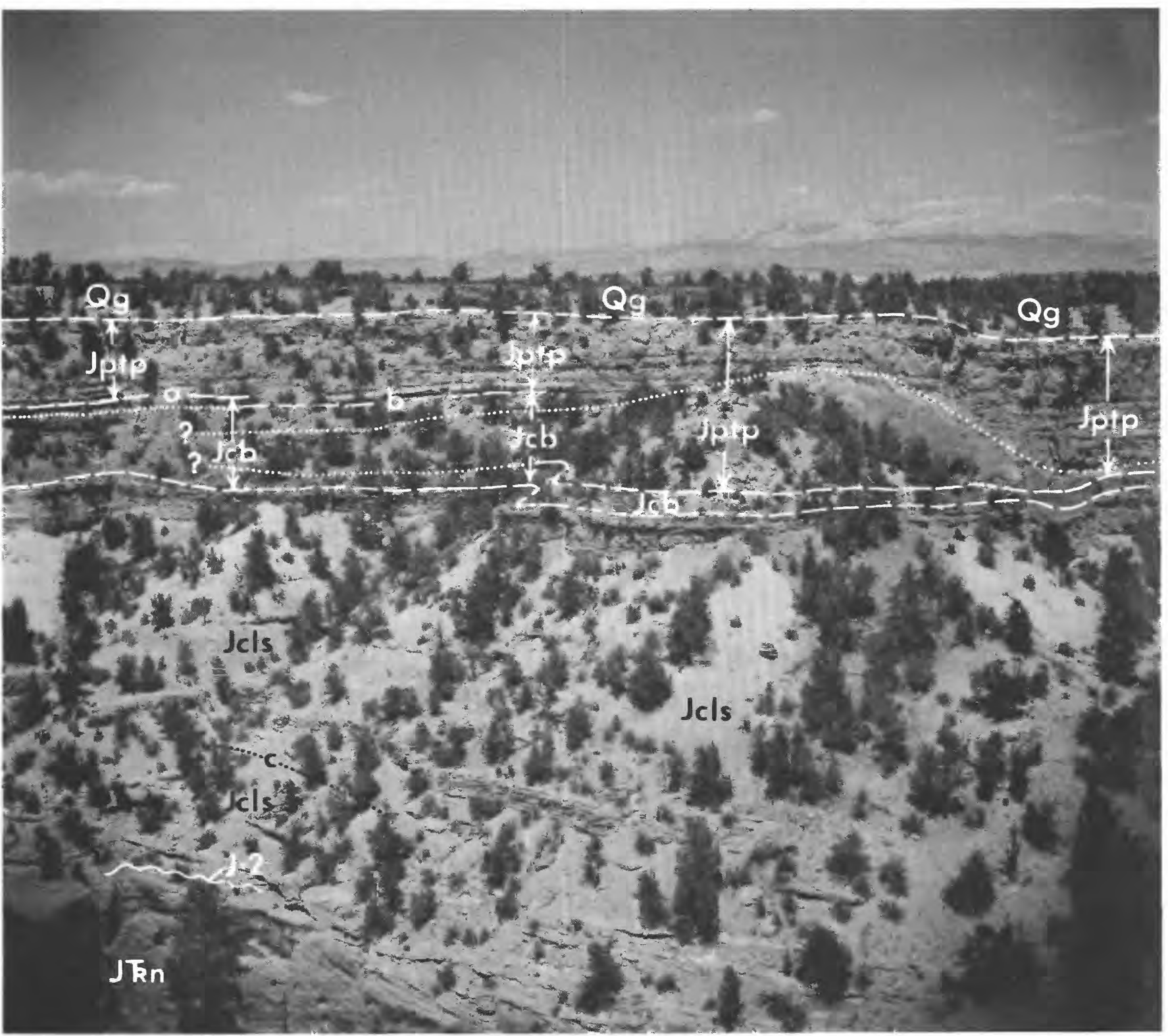

FIgURe 13.-Interfingering of banded member of Carmel Formation (Jcb) ana lower part of illiousand Pockets Tongue of Page Sandstone (Jptp) about $10 \mathrm{~km}$ southwest of Cannonville, Utah. Progressing from left to right (northwest to southeast) the upper contact of the banded member is lowered as indicated owing to pinching out of thin red mudstone marker beds ( $a$ and $b$ on photo) at the top of the member. To the right, the top of a local buildup of very thickly crossbedded sandstone in the lower part of the Thousand Pockets Tongue is outlined by dots; near the center of the view, this sandstone unit grades northwestward (left) into flat-bedded sandstone that is included in the banded member ( $\mathrm{Jcb}$ ). Truncation of the crossbedding in the sandstone buildup by the onlapping strata above it is interpreted as a local diastem rather than as part of a regional unconformity such as suggested by Thompson and Stokes (1970, p. 6). For scale, the Thousand Pockets Tongue and banded member together are about $30 \mathrm{~m}$ thick in the middle of the photo. J $\mathrm{k} n$, Navajo Sandstone; Jcls, limestone member of the Carmel Formation; dotted line and c (in Jcls), approximate contact between basal and limestone units; Qg, Quaternary gravels; dashed lines indicate formation or member contacts, dotted lines indicate correlation of units within the member; J-2, unconformity named by Pipiringos and O'Sullivan (1978). Looking north-northeast across Willis Creek Canyon in the NE $1 / 4 \mathrm{SE}^{1 / 4}$ sec. 23 , T. 38 S., R. 3 W., Kane County, Utah. 
nomenclature and recommendations are followed in this report, although it is recognized that the upper part of the Winsor is slightly younger farther northeast near the Paunsaugunt fault than it is at the type locality in Winsor Cove near Mount Carmel Junction.

The type locality of the member is in Winsor Cove (Gregory, 1950b, p. 42) about $3 \mathrm{~km}$ north of Mount Carmel Junction, Utah, where it is a poorly indurated sandstone unit that weathers to form broad slopes largely covered with soil and vegetation. The color of the member varies considerably, from moderate or dark reddish brown and grayish pink to very pale orange and very light gray. The upper $15 \mathrm{~m}$ or more is very light gray to pale orange near Mount Carmel Junction as well as farther northeast, where it is overlain by the Dakota Sandstone of Cretaceous age. The thick light-colored zone is consistently present at the top of the member and is thought to result from bleaching by solutions that percolated into the

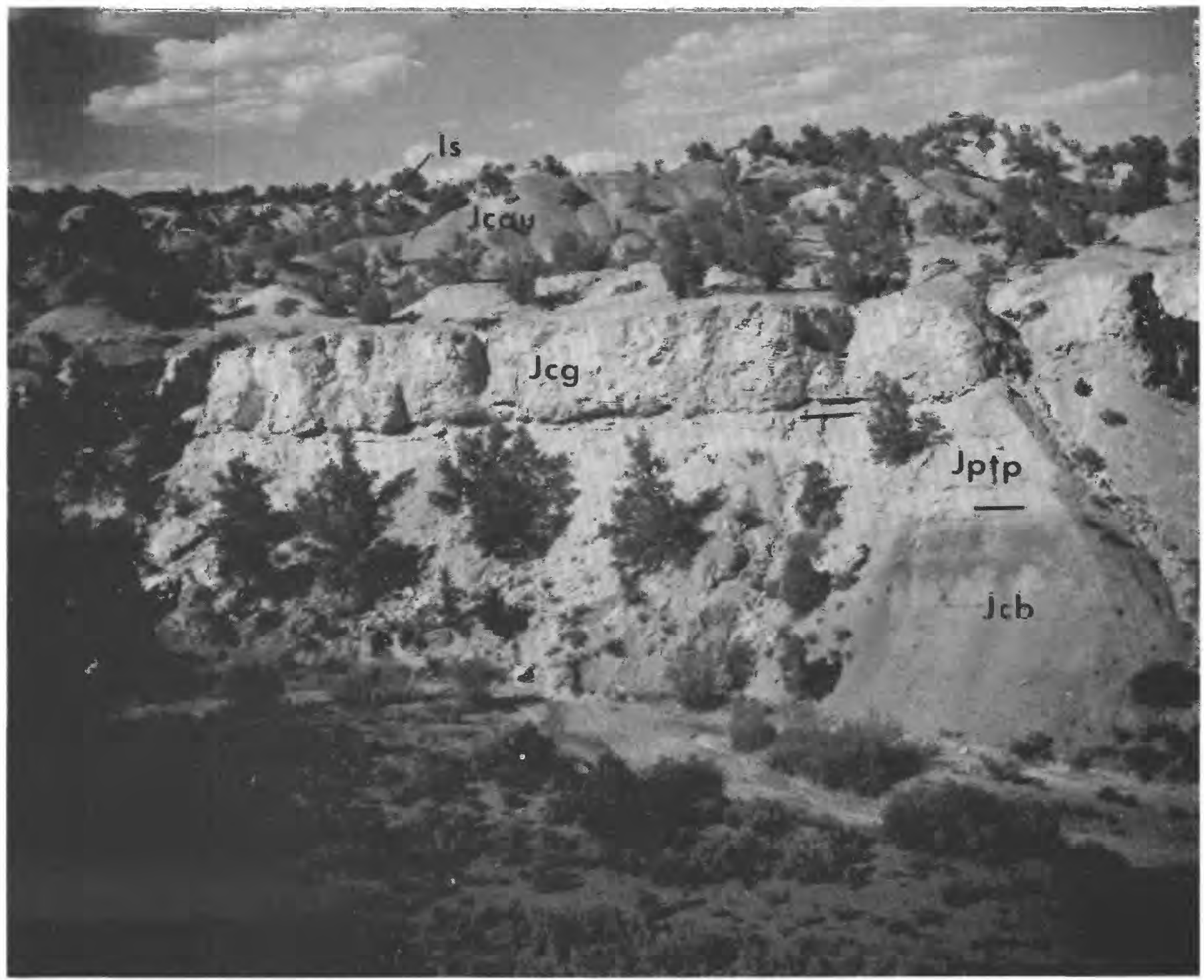

Figure 14.-The Thousand Pockets Tongue of the Page Sandstone (Jptp) and gypsiferous member of the Carmel Formation (Jcg) in Averett Canyon about $9 \mathrm{~km}$ southwest of Cannonville, Utah. The Thousand Pockets is grayish orange and forms the light-colored slope above the red slopes of the banded member of the Carmel ( $\mathrm{Jcb}$ ). The gypsiferous member consists of a cliff-forming white gypsum bed about $10 \mathrm{~m}$ thick overlain by a platy slope-forming grayish-yellow-green unit of interbedded mudstone and gypsum about $3.7 \mathrm{~m}$ thick. A thin limestone marker bed (Is) capping the ridge is included in the upper member member of the Carmel (Jcau), rather than with the gypsiferous member as had been done by previous workers. The locality is about $1.1 \mathrm{~km}$ northwest of the locality shown in figure 13 where the banded member grades southeastward into the lower part of the Thousand Pockets Tongue. Thus, the part of the banded member visible here is a facies of the lower part of the Thousand Pockets farther southeast. Looking northeast in the NW1/4 sec. 23, T. $38 \mathrm{~S}$., R. 3 W., Kane County, Utah. 
member during the erosion interval that preceded depositon of the Dakota.

The Winsor consists mostly of very fine to mediumgrained, poorly to moderately sorted, friable sandstone, pebbly sandstone, and silty sandstone. The stratification is predominantly very thin to thick bedded, although a significant fraction consists of smallto medium-scale, low- and high-angle, tabular-planar or wedge-planar cross-strata. Sets of large-scale, highangle crossbedding are present but not common. The Winsor also contains several thin beds of laminated to very thin bedded, dark-reddish-brown or yellowishgray mudstone, but because of poor exposures these beds usually are not noticed. Averitt (1962, p. 22-23) measured a section near Cedar City, Utah, that includes approximately 10-15 percent mudstone, suggesting that more mudstone is present than is generally apparent or that the amount of mudstone varies significantly from place to place. Gregory $(1950 \mathrm{~b}$, p. 41) noted that the member contains several thin lenses of limestone and gypsiferous shale northwest of Winsor Cove in southeastern Iron County, Utah. Scattered throughout the sandstone beds of the Winsor or locally concentrated in lenses up to about $0.6 \mathrm{~m}$ thick are rounded and subrounded pebbles of gray, green, or black chert, red to light-purple tuffaceous sandstone, gray or green quartzite, gray sandstone, dark-gray silicified tuff, and aphanitic or porphyritic igneous rocks as much as $5 \mathrm{~cm}$ in diameter. In addition, Gregory (1950a, p. 98) found sharply angular pebbles of limestone and rhyolite in the member.

The Winsor ranges in thickness from 54.9 to $97.2 \mathrm{~m}$ west of Mount Carmel Junction according to Gregory (1950a) and Averitt (1962). It has not been found west of the Hurricane Cliffs, where it was apparently beveled out by the unconformity at the base of the Cretaceous System. The Winsor thickens northeast of Mount Carmel Junction and reaches its maximum thickness of $204.2 \mathrm{~m}$ near Carly Knoll, about $15 \mathrm{~km}$ west of the Paunsaugunt fault (fig. 10). In this area the Winsor is composed of rocks similar to those at the type locality, but facies changes occur east of the Paunsaugunt fault and equivalent beds are included in the upper member of the Carmel Formation.

The lower contact of the Winsor is conformable and either sharp or gradational; it is placed at the top of the highest gypsum or limestone bed in the gypsiferous member of the Carmel.

\section{UPPER MEMBER}

East of the Paunsaugunt fault, strata at the top of the Carmel are informally named the upper member of the Carmel Formation. Two different facies of this member are recognized in south-central Utah, and easi- ly reached reference sections for each of these facies are given at the end of this report. The Pine Creek reference section is $5 \mathrm{~km}$ north of Escalante, Utah, where the member consists primarily of limestone in the lower part and interbedded sandstone, mudstone, and gypsum in the upper part (fig. 15). The Page, Ariz., reference section is $5 \mathrm{~km}$ north of Glen Canyon Dam, where the member consists primarily of sandstone and less abundant mudstone.

An important limestone marker bed is in the lower part of the upper member east of the Paunsaugunt fault. Just east of the fault it is about $4.9 \mathrm{~m}$ thick and consists of light-gray, laminated to very thin bedded limestone that lies about $47.2 \mathrm{~m}$ above the base of the upper member. In this area, Thompson and Stokes (1970, fig. 3) included the marker bed in the gypsiferous member (their Paria River Member of the Carmel Formation), but they miscorrelated the bed with thin limestone beds at the top of the gypsiferous member near Mount Carmel Junction. We do not include the marker bed in the gypsiferous member because the bed pinches out southwestward near the Paunsaugunt fault and is not present at the type locality of the Carmel Formation, and because the marker bed is stratigraphically higher than any part of the gypsiferous member at the type locality of the Carmel.

The limestone marker bed extends east of the Paunsaugunt fault into parts of the Kaiparowits Plateau. Between Cannonville and Escalante, Utah, in the subsurface, well logs show that several other limestone beds occur beneath the marker bed. In the exposures near Escalante, the marker bed is at the top of a sequence of beds $31.4 \mathrm{~m}$ thick at the base of the upper member of the Carmel Formation. This sequence consists of light-gray to yellowish-gray, very thin to thinbedded limestone interbedded with about 35 percent of dark-reddish-brown or scarce grayish-yellow-green, laminated to very thin bedded mudstone (fig. 11). About $20 \mathrm{~km}$ southeast of Escalante the limestone beds beneath the marker bed grade into red sandstone, silty sandstone, and mudstone; and the marker bed can be traced farther southeast along the foot of the Straight Cliffs to about $72 \mathrm{~km}$ southeast of Escalante, where it also grades into red sandstone, silty sandstone, and mudstone (fig. 11).

The marker bed can be traced underground by means of well logs to the part of Glen Canyon that lies just north of Page, Ariz. (fig. 10). In this area it is as much as $4.3 \mathrm{~m}$ thick and lies about $5.5-12.5 \mathrm{~m}$ above the base of the upper member of the Carmel Formation (Peterson and Waldrop, 1965, p. 52; Peterson, 1973, columnar section; Section 2a, unit 7, at end of this report). At its southeasternmost extent along the Straight Cliffs and in Glen Canyon north and northeast of Page, Ariz., 
the marker bed is moderate orange pink to light gray, laminated to very thin bedded limestone. Locally, it has peculiar straight lines on the bedding surfaces that intersect at right angles. These lines resemble linear markings on some maps and prompted Young (1964) to name it "maprock."

Gypsum is another rock type in the upper member that serves to distinguish it from the Winsor Member.
Near Cannonville, Utah, as many as five beds of gypsum occur in a marker zone as much as $17.1 \mathrm{~m}$ thick at the top of the upper member. This zone is composed of interbedded sandstone, silty sandstone, mudstone, and gypsum; and it is a valuable unit to use in tracing out the upper contact of the member. The sandstone and silty sandstone is red or, less commonly, white, very fine to fine grained, moderately to poorly sorted,

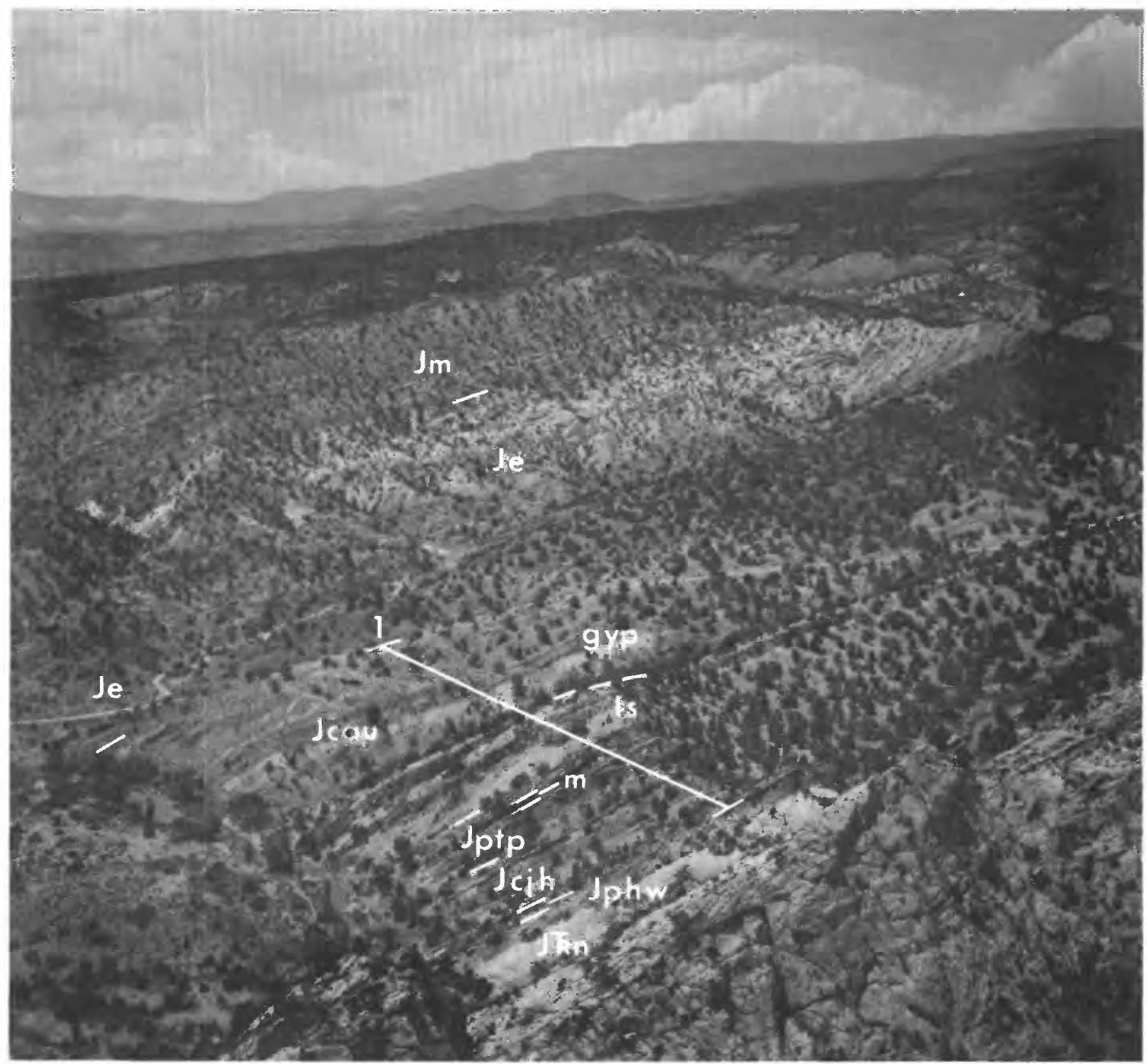

FIGURE 15.-Reference section of Carmel Formation and Page Sandstone at Pine Creek near Escalante, Utah. View is toward northwest across valley of Pine Creek. 1, reference section; Jkn. Navajo Sandstone; Jphw, Harris Wash Tongue of Page Sandstone; Jcjh, Judd Hollow Tongue of Carmel Formation; Jptp, Thousand Pockets Tongue of Page Sandstone including red marker bed shown by m; Jcau, upper member of Carmel Formation including limestone-bearing part shown by Is and gypsum-bearing part shown by gyp; Je, Entrada Sandstone; Jm, Morrison Formation. For scale, section from top of Navajo Sandstone to base of Entrada Sandstone is $162.5 \mathrm{~m}$ thick. 
and very thin to thin bedded. The mudstone is red or, less commonly, grayish yellow green and laminated to very thin bedded. The gypsum is white, light gray, and grayish yellow green and laminated to very thin bedded in strata as much as $1.2 \mathrm{~m}$ thick. The marker zone commonly weathers to slabby cliffs or to slopes littered with gypsum fragments. Southwest of Cannonville, Utah, the gypsum beds pinch out but the zone can be recognized in this area because it consists of the red lithologies noted above, interbedded with several thin beds of hard, white, fine-grained calcareous sandstone about $0.3 \mathrm{~m}$ thick. This zone persists southwestward past the Paunsaugunt fault, where it is at the top of the Winsor Member of the Carmel; and it was traced as far southwest as Carly Knoll about 35 $\mathrm{km}$ northeast of Mount Carmel Junction, where it is beveled out by the unconformity at the base of the Dakota Sandstone (fig. 10).

Northeast of Cannonville, gypsum occurs in the part of the upper member that lies above the limestone marker bed. Near Escalante, this part of the member contains approximately 12 beds of gypsum as much as $3.0 \mathrm{~m}$ thick. The gypsum beds thin and pinch out southeast of Escalante and Cannonville, and they are not present in Glen Canyon or farther southeast.

The upper member consists of a predominantly redbed facies in Glen Canyon and the region farther southeast, where it has been informally called the reservation "facies" of the Carmel (O'Sullivan and Craig, 1973, p. 79). The Page, Ariz., reference section given at the end of this report is reasonably representative of this facies, although it contains less mudstone than is usually found in this facies, and the limestone marker bed is not present in this facies southeast of Glen Canyon. A typical view of the redbed facies of the upper member is shown in figure 16.

Other than the limestone marker bed that is locally present near Page, the upper member consists of interbedded moderate-reddish-brown or scarce white sandstone, silty sandstone, and dark-reddish-brown mudstone in the eastern part of the Kaiparowits Plateau, Glen Canyon, and the region farther southeast (fig. 17). The sandstone and silty sandstone consist of coarse silt to fine-grained sand and they are poorly to moderately sorted. Scattered small pebbles like those described in the Winsor Member also occur in the upper member as far east as Kane Wash in Glen Canyon (sec. 29, fig. 10). The stratification includes laminated to thick bedding or crossbedding in sets that generally are small to medium scale low angle and tabular planar or wedge planar. Locally the sandstone contains one or several sets of large-scale high-angle tabular-planar crossbedding. At the excellent exposures along U.S. Highway 89 near West Cove (sec.
24, fig. 10), large-scale crossbedding occurs in the middle of the member in a conspicuous very light gray cliff-forming sandstone unit $40.2 \mathrm{~m}$ thick that can be mistaken from the Entrada Sandstone. Intraformational slumps, faults, and breccia pipes are locally present in the upper member just east of the Paria River. near Cannonville, Utah.

The greatest known thickness of the upper member is $205.1 \mathrm{~m}$ at Bull Valley about $13 \mathrm{~km}$ southwest of Cannonville, Utah (sec. 17, fig. 10). It thins to about $113.4 \mathrm{~m}$ at the reference section of the Carmel at Pine Creek, near Escalante, Utah, and to about $77.7 \mathrm{~m}$ at the other reference section near Page, Ariz. The thinnest section that was measured is $38.1 \mathrm{~m}$ near Navajo Point about $48 \mathrm{~km}$ northeast of Page.

The contact of the upper member with the underlying gypsiferous member of the Carmel is sharp or gradational, and it is placed at the top of the highest gypsum or limestone bed of the gypsiferous member. Where the gypsiferous member pinches out, the contact with the underlying Page Sandstone generally is sharp, and it is placed at the top of the highest crossbedded sandstone of the Page and at the base of the lowest flat-bedded sandstone, silty sandstone, or mudstone of the upper member. Southeast of Glen Canyon where the upper member rests directly on the Navajo Sandstone, the contact is sharp, and it is placed at the top of the highest crossbedded Navajo Sandstone and at the base of the lowest flat-bedded sandstone or silty sandstone that contains scattered small, angular chert pebbles. The contact with the Navajo is the same J-2 unconformity that separates the limestone member of the Carmel from the Temple Cap Sandstone farther west in southwestern Utah (figs. 10, 11), but the contact of the upper member with the Page Sandstone is not an unconformity.

Interfingering of the lower approximately $3 \mathrm{~m}$ of the upper member with the upper part of the Page Sandstone was found at one locality in Glen Canyon about $14 \mathrm{~km}$ northeast of Page, Ariz., demonstrating that this contact is not an unconformity (fig. 10). Correlations $45 \mathrm{~km}$ southeast of Escalante, Utah, in the Early Weed Bench area (fig. 11), suggest that the lowermost beds of the upper member are time-equivalent to the Judd Hollow Tongue of the Carmel Formation and the Thousand Pockets Tongue of the Page Sandstone. In this area the Judd Hollow Tongue grades southeastward into sandstone that is included in the Page Sandstone because it is crossbedded, but it can be distinguished and traced because it is considerably darker (very dark red to very dusky red) than the rest of the crossbedded sandstone in the Page. This darker bed was traced southeast along the north side of Early Weed Bench to section 36 (fig. 11), where the overlying 


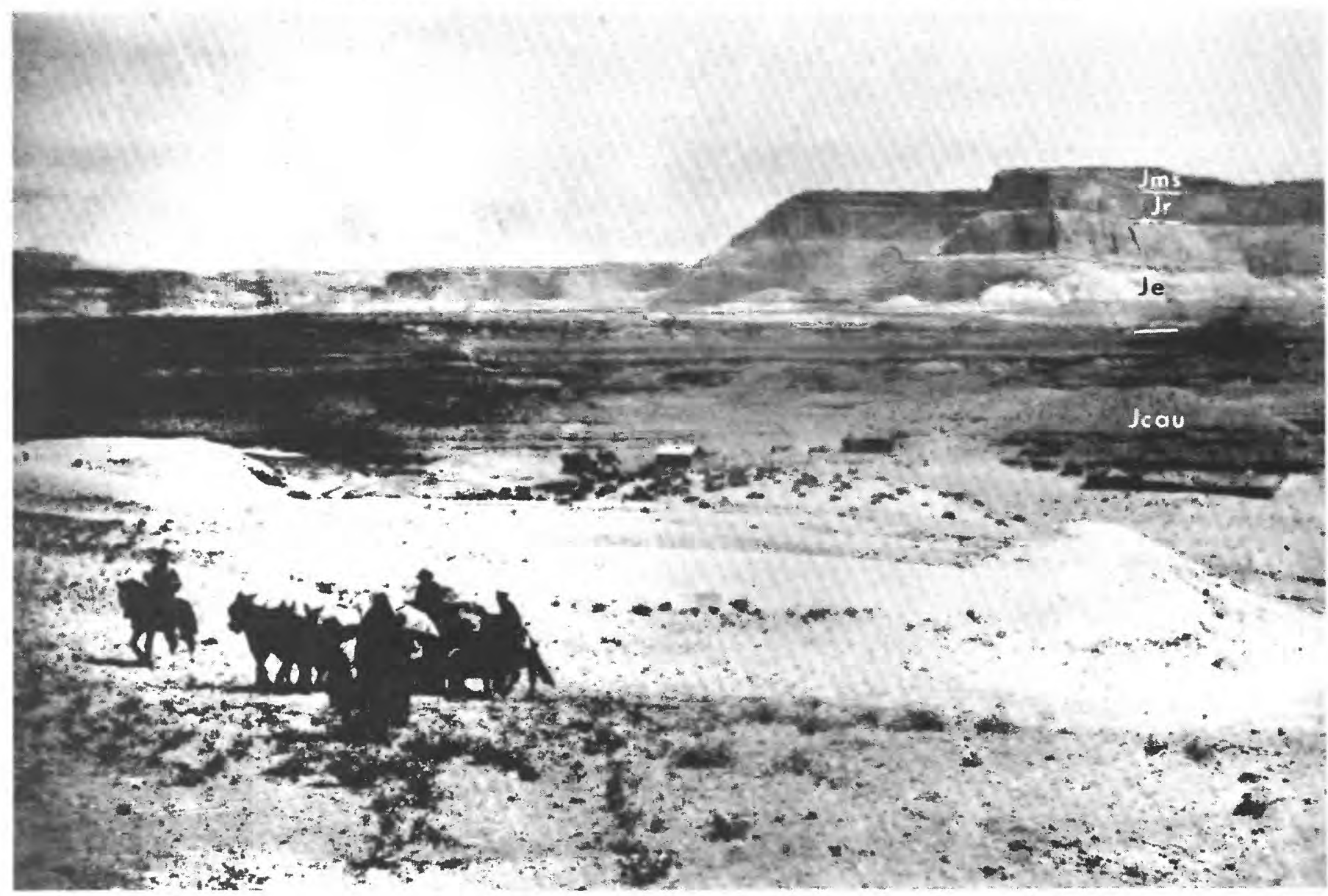

Figure 16. - Typical exposures of ledges and broad slopes in the upper member of the Carmel Formation (Jcau) at canyon of Warm Creek in southern part of Kaiparowits Plateau. The small cliffs in the member are sandstone whereas the slopes are underlain by interbedded sandstone, silty sandstone, and mudstone similar to the strata described in the reference section of the Carmel at Page approximately $7 \mathrm{~km}$ southwest of here (measured section 2a). The upper member is predominantly red, and it contrasts markedly in color and topographic expression with the Entrada Sandstone (Je), sandstone at Romana Mesa (Jr), and Salt Wash Member of the Morrison Formation (Jms) on walls of Romana Mesa in the distance. The buildings and associated structures are an abandoned depot that was built about 1910-1911 and used as part of an ambitious project to haul coal out of the Kaiparowits Plateau and down the Colorado River to Lees Ferry, Ariz., for use in gold-mining endeavors by C. H. Spencer (Gregory and Moore, 1931, p. 148; Crampton, 1964, p. 142). The buildings and most of the Carmel Formation here are now covered by the waters of Lake Powell. Photo by R. C. Moore, 1921, in the NW1/4 sec. 35, T. 43 S., R. 4 E., Kane County, Utah.

crossbedded sandstone, equivalent to the Thousand Pockets Tongue, thins and pinches out and the hard, dark-colored, crossbedded sandstone, equivalent to the Judd Hollow, is overlain directly by the upper member of the Carmel. Farther southeast, a transition zone approximately $6.6 \mathrm{~m}$ thick at the base of the upper member consists of very thin to thin-bedded and smallto medium-scale crossbedded sandstone that probably correlates with the Judd Hollow and possibly with the Thousand Pockets Tongue farther northwest. A hard, dark-colored, crossbedded sandstone facies of the Judd Hollow Tongue also is present on the south side of the Kaiparowits Plateau (fig. 24), but this unit grades eastward into crossbedded strata that are indistinguishable from the enclosing Page Sandstone.

\section{PAGE SANDSTONE}

The Page Sandstone is here named for a cliff-forming crossbedded, red or light-gray sandstone formation in south-central Utah and north-central Arizona. Rocks now assigned to the Page were considered part of the Navajo Sandstone by previous workers, but recent work indicates that the Page is younger than the Navajo; and they are separated by a regional erosion surface termed the J-2 unconformity by Pipiringos and O'Sullivan (1978). The Page is included in the San Rafael Group because: (1) it is separated from the Glen Canyon Group by the J-2 unconformity, (2) it is younger than the Temple Cap Sandstone, which is also included in the San Rafael Group, (3) it is the same age as the lower part of the Carmel Formation of the San 


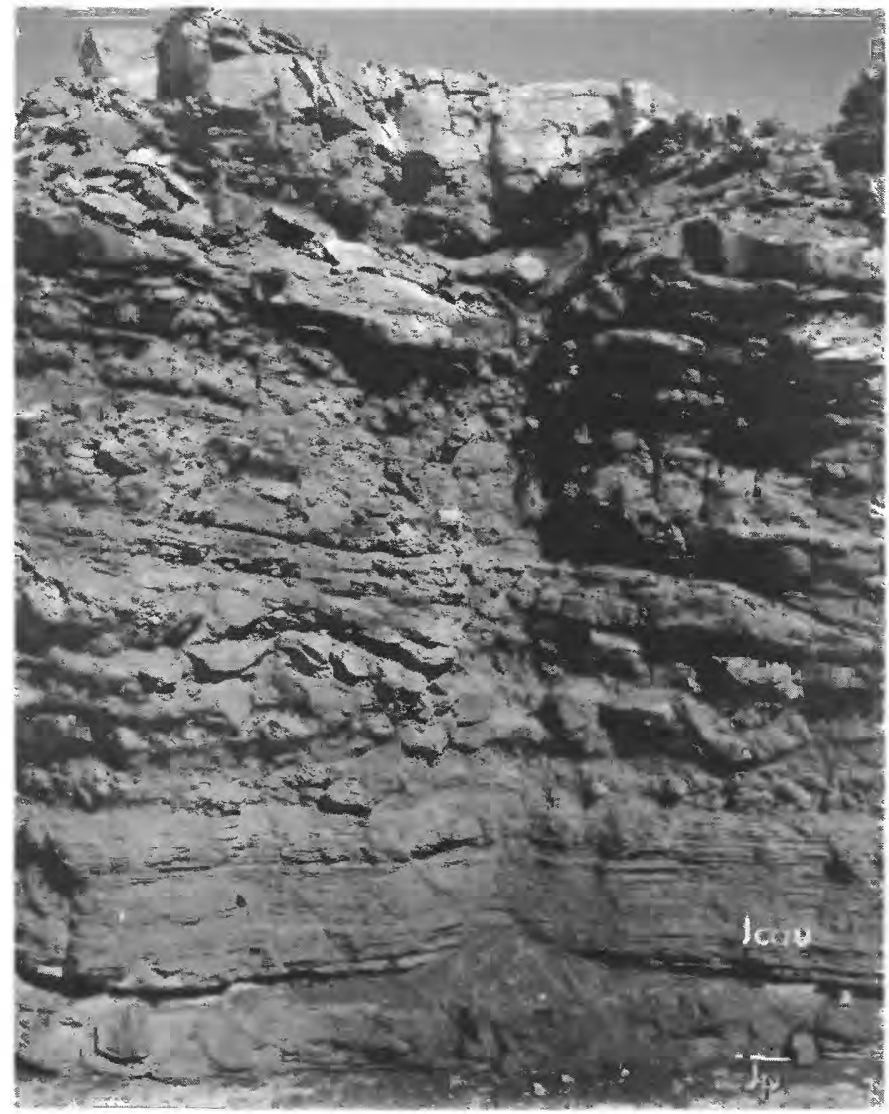

Figure 17.-Good exposures of interbedded lithologies in lower part of upper member of Carmel Formation (Jcau) about $50 \mathrm{~km}$ southeast of Escalante, Utah. The cliff is about $15 \mathrm{~m}$ high and contains, in ascending order, a thin basal stratum of light-red sandstone overlain by laminated red mudstone and gray gypsum; irregularly thin bedded to thick bedded red sandstone, silty sandsandstone, and mudstone in the middle; and a capping bed of white sandstone. The irregular, lenticular, and somewhat contorted bedding in the middle is fairly common in the member. The pack in the lower right rests on the uppermost part of the Page Sandstone (Jp). Looking southeast across a small tributary of Big Hollow Wash in the SE $1 / 4$ sec. 8 , T. 39 S., R. 7 E., Kane County, Utah.

Rafael Group, and (4) for simplicity of stratigraphic classification.

The Page Sandstone is $55.8 \mathrm{~m}$ thick at the type section near Page, Ariz. (section $2 \mathrm{~b}$ at end of this report), and it attains its greatest known thickness of $88.7 \mathrm{~m}$ about $18 \mathrm{~km}$ farther south. It pinches out about $40 \mathrm{~km}$ southeast of Page and on the northwest flank of Navajo Mountain about $50 \mathrm{~km}$ east of Page. Progressing northwestward from the type locality, the Page is split into two tongues by the southeastward-thinning Judd Hollow Tongue of the Carmel Formation. The lower of these tongues is here named the Harris Wash Tongue of the Page Sandstone and the upper tongue is the Thousand Pockets Tongue. The Thousand Pockets was named by Phoenix (1963), who assigned it to the Navajo Sandstone, but it is reassigned here to the Page Sandstone.

The type section of the Page Sandstone is on the northwest side of Manson Mesa on which the town of Page, Ariz., is situated, and it is about $1 \mathrm{~km}$ northeast of Glen Canyon Dam (fig. 18). At this locality the formation consists largely of moderate-reddish-brown, moderate-reddish-orange, and locally very light gray or grayish-pink sandstone that is fine grained and well sorted. The crossbedding is predominantly large scale and of low- or high-angle, tabular-planar, and wedgeplanar types. The crossbedding sets range in thickness from $1 \mathrm{~m}$ to about $6 \mathrm{~m}$, although locally near Escalante, Utah, sets as much as $18.3 \mathrm{~m}$ thick occur. In places the sandstone includes several thin beds as much as $0.3 \mathrm{~m}$ thick of laminated to very thin bedded, very fine to fine-grained, moderately sorted, moderatereddish-brown sandstone.

A small but important constituent of the Page Sandstone is small angular pebbles of chert. These have microcrystalline or colloform texture and are white to very pale orange, although less commonly they are moderate red to moderate reddish orange. At the type locality the pebbles are less than $5 \mathrm{~mm}$ long (fig. 19), but throughout most of the region the maximum size is about $1.3 \mathrm{~cm}$. Locally, the pebbles are as much as 6.4 cm long, and at one locality about $24 \mathrm{~km}$ east of Escalante, Utah, a cobble $25 \mathrm{~cm}$ long and about $3.8 \mathrm{~cm}$ in diameter was found. The pebbles generally occur scattered along the basal contact or in the basal $15 \mathrm{~cm}$ of the formation. They have also been found higher in the formation at several localities, where they occur scattered along some of the bedding surfaces; but they are consistently larger and more abundant at the base of the formation.

The basal contact of the Page Sandstone is a sharply defined and continuous surface that is characterized in most places by a thin layer of scattered angular chert pebbles. It is generally expressed topographically as a bench about a meter to a kilometer wide stripped back on the top of the Navajo (figs. 4 and 18) or as a prominent incised notch in the cliffs of Glen Canyon (fig. 20). This surface is considered an unconformity because it has features associated with it that indicate extensive weathering or erosion, and because it truncates underlying formations. The unconformity occurs throughout much of the Western Interior of the United States where it was described by Pipiringos (1967, 1968) and Pipiringos and O'Sullivan (1975). The surface was formerly known as the chert pebble unconformity, but more recently it was named the J-2 unconformity by Pipiringos and O'Sullivan (1978). Discovery of this unconformity in southwestern Utah is especially 


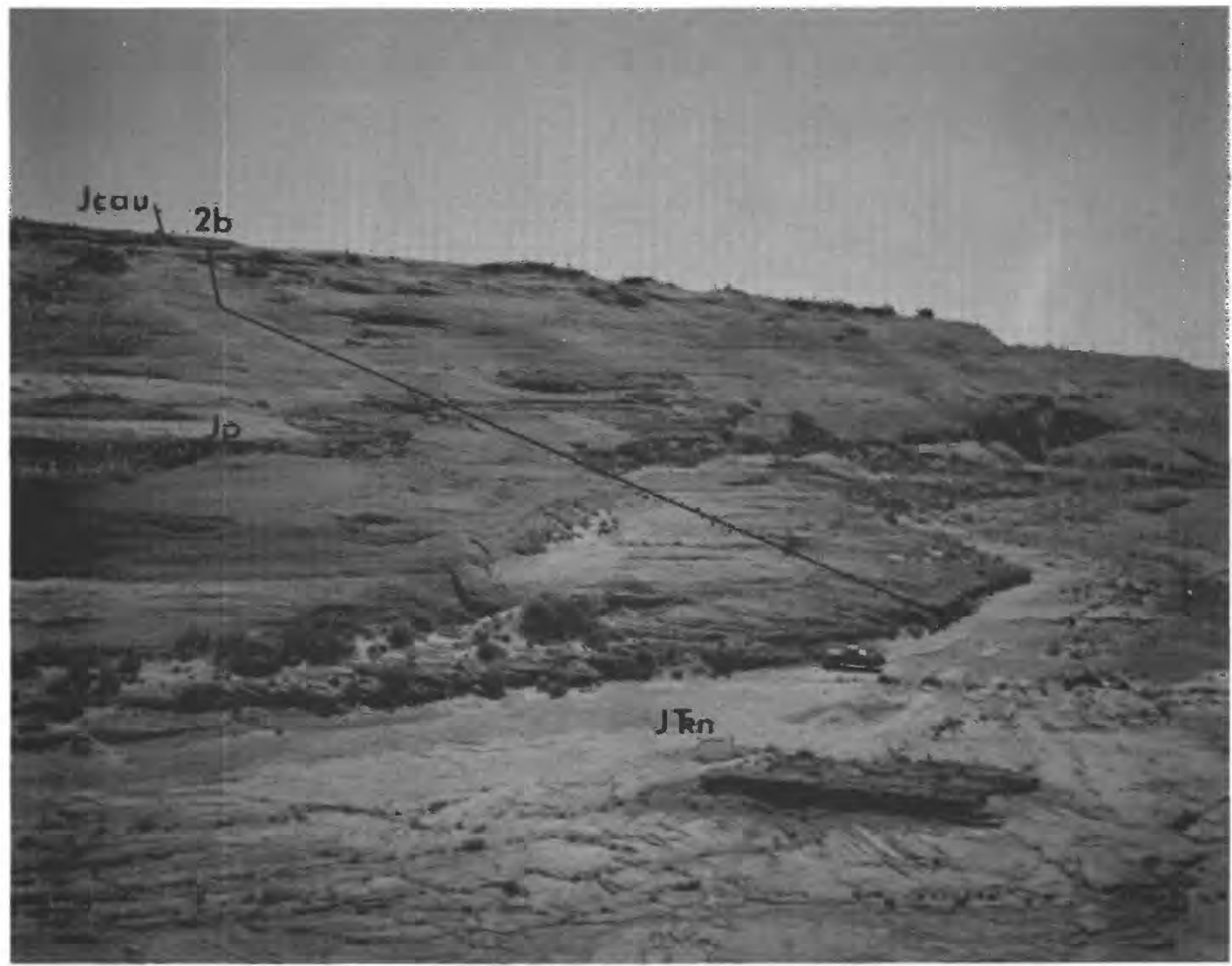

Figure 18.-Type section of Page Sandstone near Page, Ariz. The stripped surface in the foreground at the base of the Page (Jp) is a typical topographic feature marking the top of the Navajo Sandstone (Jk n). 2b, type measured section; the Page is 55.8 m thick. Jcau, upper member of Carmel Formation. View is southeast toward northwest side of Manson Mesa.

significant because it serves to demonstrate that the Navajo Sandstone and Carmel Formation do not interfinger as had been thought by previous workers.

The scattered angular chert pebbles such as shown in figures 19 and 21 generally are the most reliable feature to use in locating the basal contact of the Page Sandstone. These pebbles have the same color and texture as the authigenic chert that occurs as irregular nodules in the underlying Navajo Sandstone, suggesting that the pebbles originally came from that formation. Also, the angularity of the pebbles indicates a nearby source that could only be the Navajo. Considering the widespread distribution of the Navajo throughout most of southern Utah and northern Arizona in Early Jurassic time (Baker and others, 1936 , p. 47), it would take an extraordinary set of sedimentary processes to bring a similar suite of pebbles into the region from localities outside the limits of the Navajo Sandstone without rounding the pebbles considerably and without incorporating other rock types into the pebble suite. The evenly distributed angular pebbles in a thin layer on the unconformity are similar to deflation-lag gravels in modern deserts where the angularity of the pebbles is caused by splitting from insolation (Glennie, 1970, p. 16-21; Walker and Harms, 1972, p. 284-287). Similar but smaller detrital chert pebbles locally occur at higher stratigraphic levels in the Page but they have not been found in the Navajo. Thus, the lowest level of detrital chert pebbles usually is the best criterion to use in locating the basal contact of the Page Sandstone.

Another feature commonly found at the lower con- 
tact of the Page Sandstone is downward-tapering sandstone-filled crevices that probably mark fossil joints. In many places where the strata can be viewed in a vertical section, the contact is indented about every $3-15 \mathrm{~m}$ with crevices up to $15 \mathrm{~cm}$ wide at the top, which extend down as much as $1.8 \mathrm{~m}$ into the Navajo Sandstone (fig. 22). The sandstone that fills the crevices is vertically continuous with the sandstone in the overlying strata of the Page Sandstone. Angular chert pebbles, so commonly found elsewhere along this surface, also occur in some of these crevices. On horizontal surfaces where the Page is stripped off and the crevices can be examined in plan view, the linear or sinuous trend of isolated crevices can be traced for 15 $\mathrm{m}$ or more, and abundant swarms of crevices are interconnected to form polygons $1.5-3.0 \mathrm{~m}$ in diameter (fig. 23). The crevices are similar to presentday linear, sinuous, and polygonal joints that weather out of the Navajo Sandstone. For this reason it is thought that the crevices formed by weathering along ancient joints in the Navajo prior to deposition of the Page Sandstone and were filled with sand during the earliest stages of deposition of the Page.

Small sandstone-filled crevices locally occur at the base of some of the thin flat-bedded sandstone units higher in the Page Sandstone. They are generally smaller than those at the top of the Navajo, being several centimeters wide at the top and pinching out about 0.3-0.6 $\mathrm{m}$ into the underlying sandstone. These probably are ancient joint crevices or shrinkage cracks that formed during brief periods when sand deposition ceased and the surface became sufficiently lithified to allow them to form. Because these fossil joint crevices or shrinkage cracks occur within the Page but have not been found below the upper surface of the Navajo, the lowest level of these crevices is another important feature that marks the basal contact of the Page Sandstone.

The uppermost part of the Navajo has an irregular light-colored or bleached zone at many localities that is also helpful in locating the basal contact of the Page Sandstone (figs. 24 and 25). In general, the bleached zone is very light gray to grayish pink, but locally it is only a slightly grayer shade of red than the unaltered strata. The top of the zone coincides with the upper contact of the Navajo, whereas the lower boundary of the zone may be gradational or sharp, and in many places it cuts across the cross-laminae in the formation. The thickness of the bleached zone varies considerably, from less than a meter to about $300 \mathrm{~m}$, and in the Waterpocket Fold and Circle Cliffs areas the zone extends throughout the Navajo (Smith and others, 1963; Davidson, 1967). The light-colored zone probably was caused by fluids that seeped down into the Navajo and bleached the upper part of it during the erosion interval that produced the J-2 unconformity. Similar bleached zones occur beneath many of the other Jurassic as well as Cretaceous unconformities in the region, especially where the underlying beds are porous and permeable and where the erosion surface had been exposed to subaerial weathering processes.

Locally, the basal stratum of the Page Sandstone contains light-colored reworked or residual deposits derived from the underlying Navajo Sandstone. These beds generally are less than $0.3 \mathrm{~m}$ thick and consist of very thin but irregularly bedded sandstone that is similar in color and texture to the sandstone in the bleached zone at the top of the Navajo. This similarity of color and texture as well as the lack of currentproduced bedding structures suggests that the sand in these beds came from the bleached zone at the top of

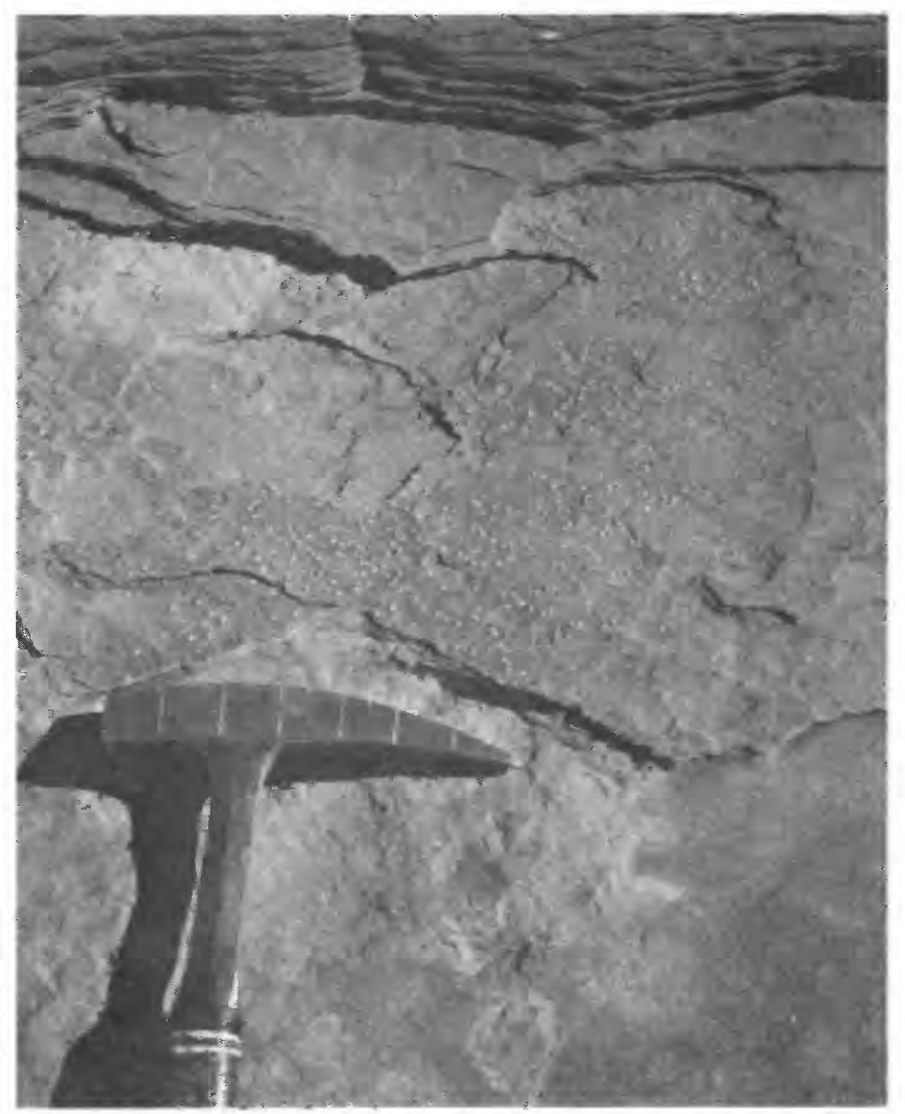

FIGURE 19.-Evenly distributed small angular chert pebbles at base of Page Sandstone at the type section near Page, Ariz. The pebbles are as much as $5 \mathrm{~mm}$ long, and most are white to very pale orange, although some are moderate red or moderate reddish orange. Scarce pebbles locally occur higher in the Page, but they have not been found below it in the Navajo Sandstone. Thus, the lowest level of detrital chert pebbles marks the lower contact of the Page Sandstone. The pick head (scaled in inches) rests on the uppermost part of the Navajo Sandstone and the surface was brushed clean of all loose detritus before the photo was taken. 


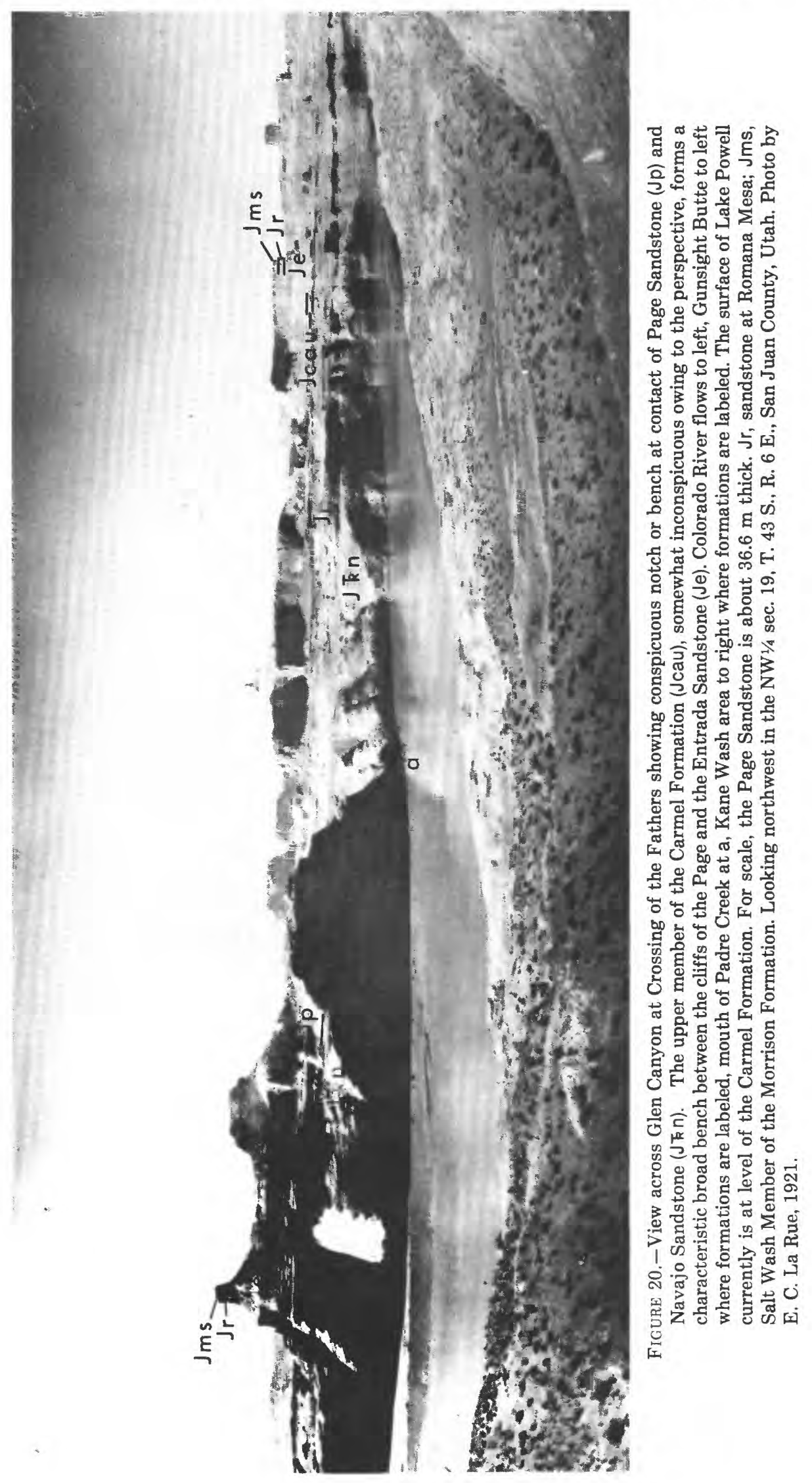


the Navajo, mainly through weathering in place with little lateral transportation or admixture of new sediment from other sources.

Small sandstone nodules cemented mainly with silica commonly occur in the upper part of the bleached zone of the Navajo where it is overlain by the Page Sandstone (fig. 26). The nodules are about $1.3-2.5 \mathrm{~cm}$ in diameter and they are the same light-gray or lightred color as the enclosing sandstone in the bleached zone. The cementing material is mainly silica although weak effervescence with dilute hydrochloric acid suggests that a small quantity of calcite cement also is present. Bedding laminae pass directly through the nodules, indicating that they formed by precipitation of the cementing material in the intergranular pore spaces after deposition of the Navajo, and similarity of the color of the sandstone in them to that of the enclosing bleached zone suggests that they formed at the same time as that zone or slightly later. Both the bleached zone and the small nodules in the upper part of the Navajo are readily identified on many outcrops, and they are additional guides to locating the basal contact of the Page Sandstone.

A moderate amount of local erosional relief on the top of the Navajo is indicated by buried hills of Navajo

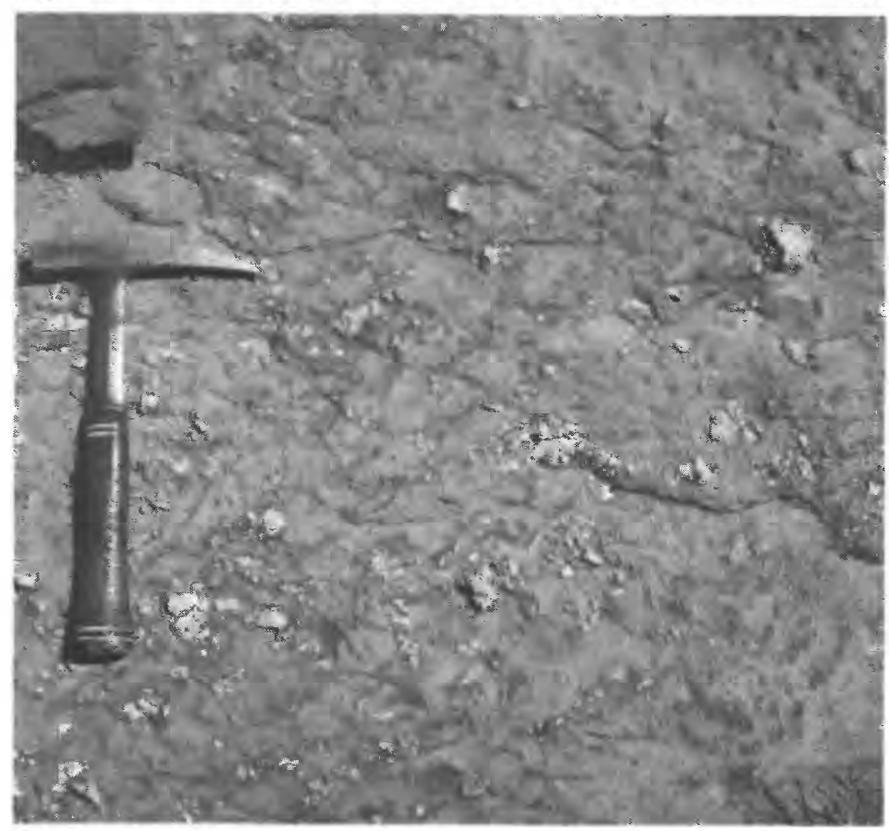

FIGURE 21.-Angular chert pebbles embedded in basal stratum of Page Sandstone. The angularity of the pebbles, indicating a nearby source, and position high on the flank of the buried hill of Navajo Sandstone shown in figure 27, indicate that they could only have come from the top of that hill. Presumably the hill was originally capped with a cherty limestone bed similar to the one in the Navajo Sandstone shown in figure 5, and the pebbles were derived from it by weathering processes early in the depositional history of the Page Sandstone. Scale on pick head is in inches; the surface to the right of the pick was brushed clean of all loose detritus before the photo was taken. Cave Point area in the NW $1 / 4$ sec. 35 , T. 40 S., R. 8 E., Kane County, Utah.
Sandstone preserved beneath the Page Sandstone or upper member of the Carmel Formation (fig. 27). Thus far, four of these hills have been found in the eastern part of the Kaiparowits Plateau about 40-50 km northeast of Page, Ariz., and about $70-80 \mathrm{~km}$ southeast of Escalante, Utah. The hills are as much as $11.3 \mathrm{~m}$ high, and they extend up to or slightly above the top of the surrounding Page Sandstone, so that they are directly overlain by the upper member of the Carmel Formation. In cross section they are about 150-460 m wide. Chert pebbles along the unconformity are larger (as much as $6.4 \mathrm{~cm}$ long) and more abundant on the crest or flanks of these hills (fig. 21), suggesting that they were originally capped with a protective bed of cherty limestone in the Navajo that was the source of the pebbles. The cherty limestone bed shown in figure 5 is the capping stratum of one of these buried hills in Dangling Rope Canyon about $50 \mathrm{~km}$ northeast of Page, Ariz. No alinement of the hills could be determined; instead, they seem to be randomly distributed erosional remnants whose preservation was determined solely by the presence of a resistant cherty limestone bed in the Navajo Sandstone.

Smaller erosional irregularities occur at the top of the Navajo, where they are preserved beneath the Page Sandstone. These include small knolls, cliffs, and overhanging ledges $0.3-1.0 \mathrm{~m}$ high, such as are shown in figure 28. Small shallow depressions as much as $1 \mathrm{~m}$ deep and 3-6 $\mathrm{m}$ wide were also found on this surface, but they are not considered fluvial channels because they do not contain deposits typical of fluvial deposition. Indeed, no strata containing bedding or textural features typical of fluvial deposits were found in either the Navajo or Page Sandstone. The buried hills and small-scale erosional irregularities at the top of the Navajo indicate that it was fairly well lithified when the Page sediments were being deposited, and the relatively greater degree of lithification of the Navajo apparently has been maintained throughout geologic time in most places.

Eastward or southeastward regional beveling of older rocks by the J-2 unconformity at the base of the Carmel or Page Formation is indicated by eastward truncation of the Temple Cap Sandstone in southwestern Utah (figs. 8, 10), southeastward truncation of the Navajo Sandstone in northeastern Arizona and southwestern Colorado (fig. 2; Harshbarger and others, 1957, p. 21, 33; Shawe and others, 1968, p. A38-A41), and eastward truncation of older formations in west-central Colorado (Craig and Dickey, 1956, p. 97). Similar southeastward regional beveling of older formations by the J-2 unconformity has been well documented in south-central Wyoming (Pipiringos, 1968, p. D3), where this unconformity is at the base of the Sundance Formation. 


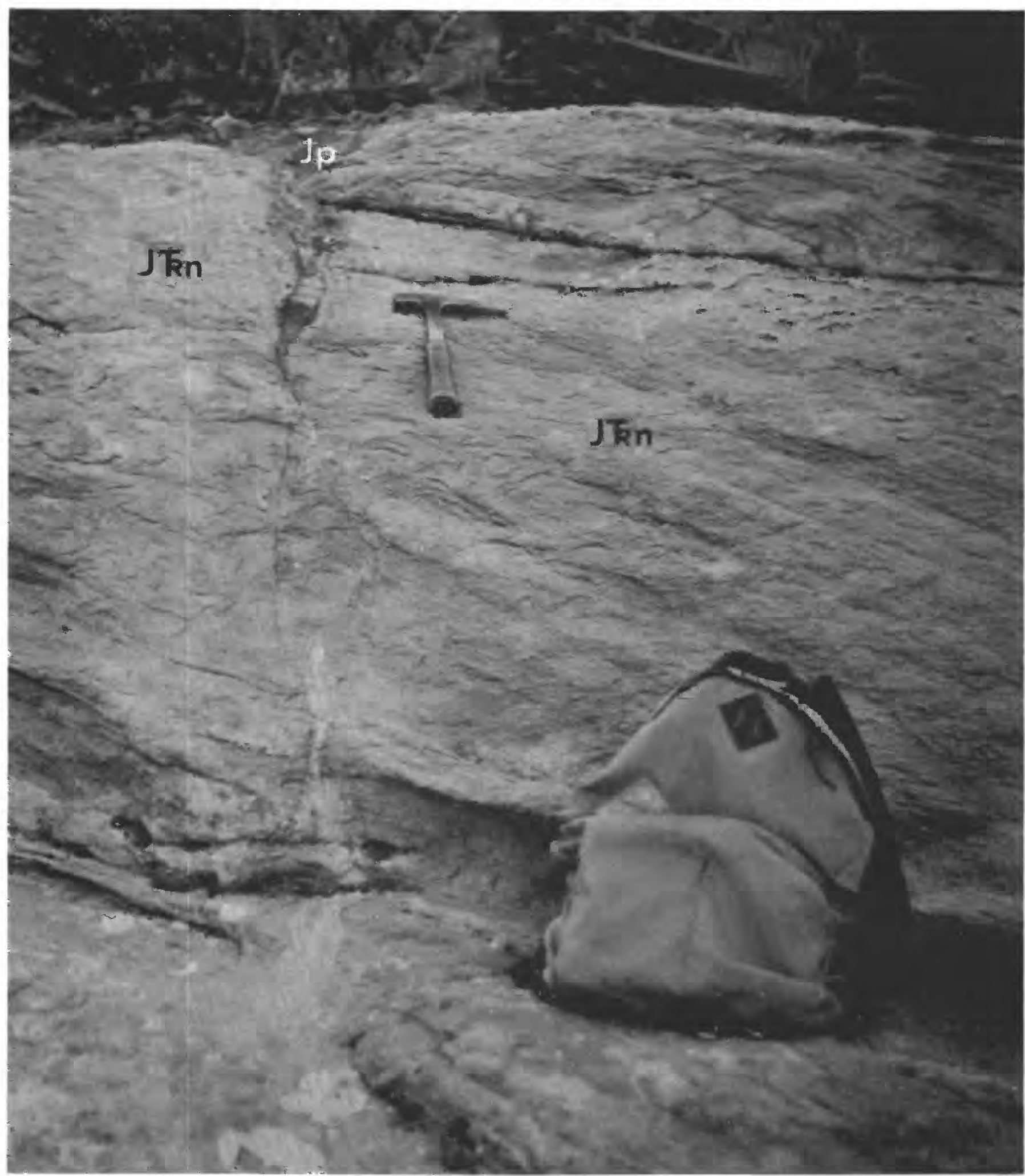

Figure 22.-Fossil joint crevice at top of Navajo Sandstone. The Page Sandstone (Jp) fills the crevice down about $1.2 \mathrm{~m}$ to the level of the base of the pick and the fracture extends down $0.6 \mathrm{~m}$ more to about the level of the middle of the pack where a narrow vertical bleached zone is present in the Navajo Sandstone $(\mathrm{J} \hbar \mathrm{n})$. Although not apparent, several small angular chert pebbles are present in the part of the Page Sandstone that fills the crevice. Looking east and up on the east side of Dangling Rope Canyon about $6.4 \mathrm{~km}$ southwest of Navajo Point in the SE1/4 sec. 30, T. 32 S., R. 8 E., Kane County, Utah. 


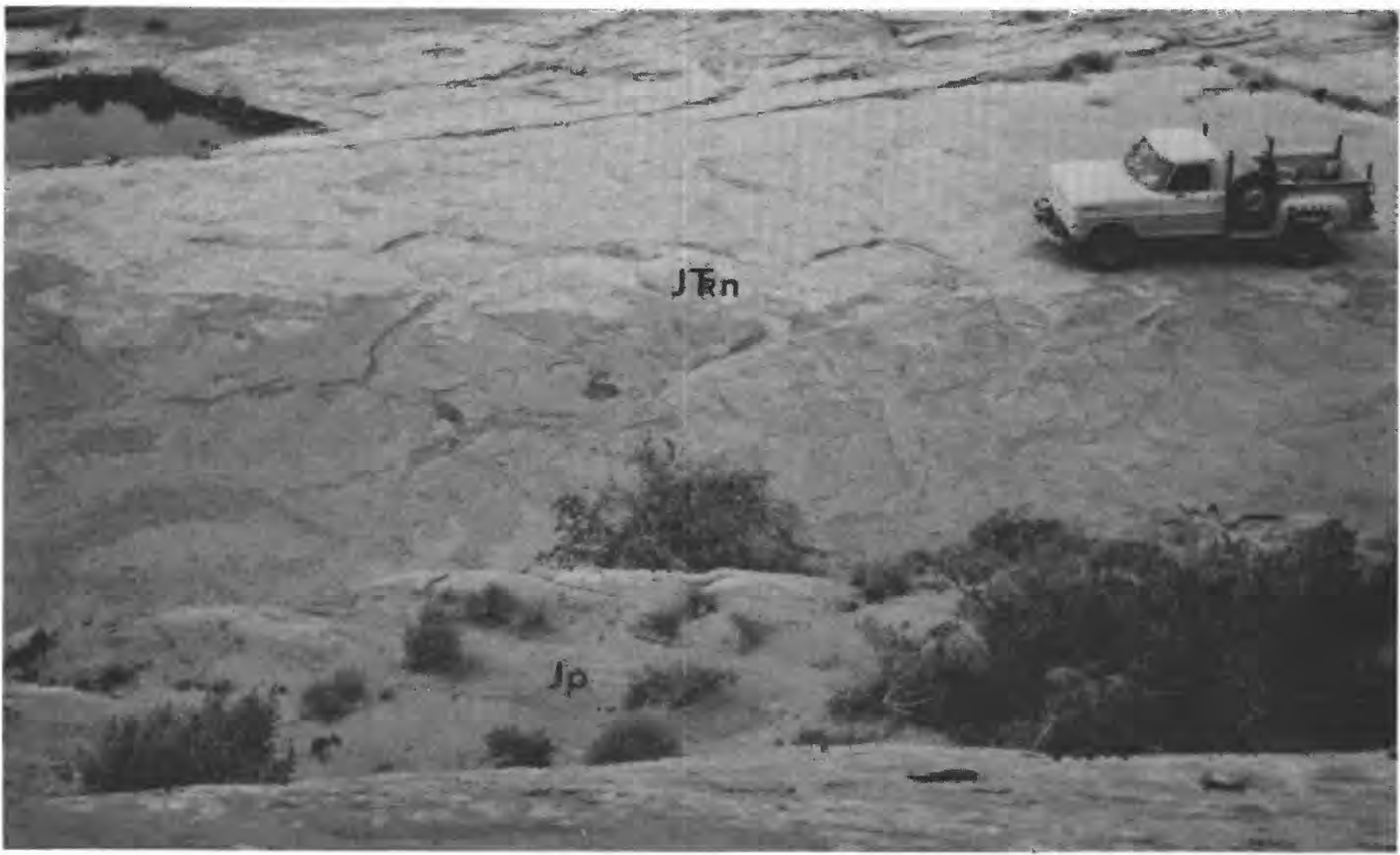

FIGURE 23.-Plan view of fossil joint crevices at top of Navajo Sandstone (Jkn). The polygonal distribution of the ancient crevices filled with Page Sandstone (Jp) is similar to the polygonal distribution of modern joint crevices in the Navajo and suggests a similar origin. Northwest side of Manson Mesa at type section of Page Sandstone near town of Page, Ariz.

\section{HARRIS WASH TONGUE}

The Harris Wash Tongue of the Page Sandstone is here proposed for a westward-thinning unit of crossbedded sandstone at the base of the Page Sandstone. The tongue takes its name from the type section in a small tributary to Harris Wash about $20 \mathrm{~km}$ southeast of Escalante, Utah (fig. 29). It weathers to form a cliff that in places may be vertically continuous with the sheer cliff at the top of the Navajo Sandstone,

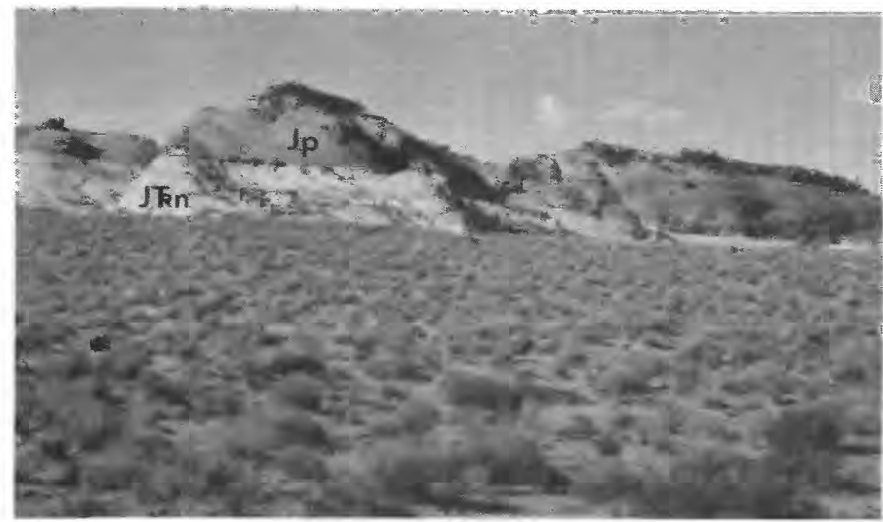

but more commonly it is set back slightly $(0.3-30 \mathrm{~m})$ from the Navajo cliff.

The Harris Wash Tongue thins irregularly westward in the western part of the Kaiparowits Plateau and along the Waterpocket monocline about $50-80 \mathrm{~km}$ farther north. It reaches a maximum thickness of about $36.6 \mathrm{~m}$ on the northeast side of the Kaiparowits Plateau about $45 \mathrm{~km}$ southeast of Escalante, Utah. Near Escalante, the tongue is only $4.6 \mathrm{~m}$ thick, and, judging from the rate of westward regional thinning, it

FIgure 24.-Conspicuous difference in colors of Navajo and Page Sandstones at Thousand Pockets about $8 \mathrm{~km}$ west of Page, Ariz. The J-2 unconformity marked by small angular chert pebbles is at the base of the darker Page Sandstone (Jp; actually moderate reddish brown), which lies on the nearly white discolored zone at the top of the Navajo Sandstone $(J K n)$. The discoloration is attributed to bleaching prior to deposition of the Page, probably by fluids that seeped into the Navajo during the erosion interval that produced the unconformity. The cuesta is capped by a thin, hard, very dark red crossbedded sandstone unit in the Page that correlates with the Judd Hollow Tongue of the Carmel Formation about $8 \mathrm{~km}$ farther northwest. For scale, the part of the Page Sandstone visible in the cuesta is about $21.3 \mathrm{~m}$ thick. View is northwest in the SW $1 / 4$ sec. 24 , T. 41 N., R. 7 E., Coconino County, Ariz. 


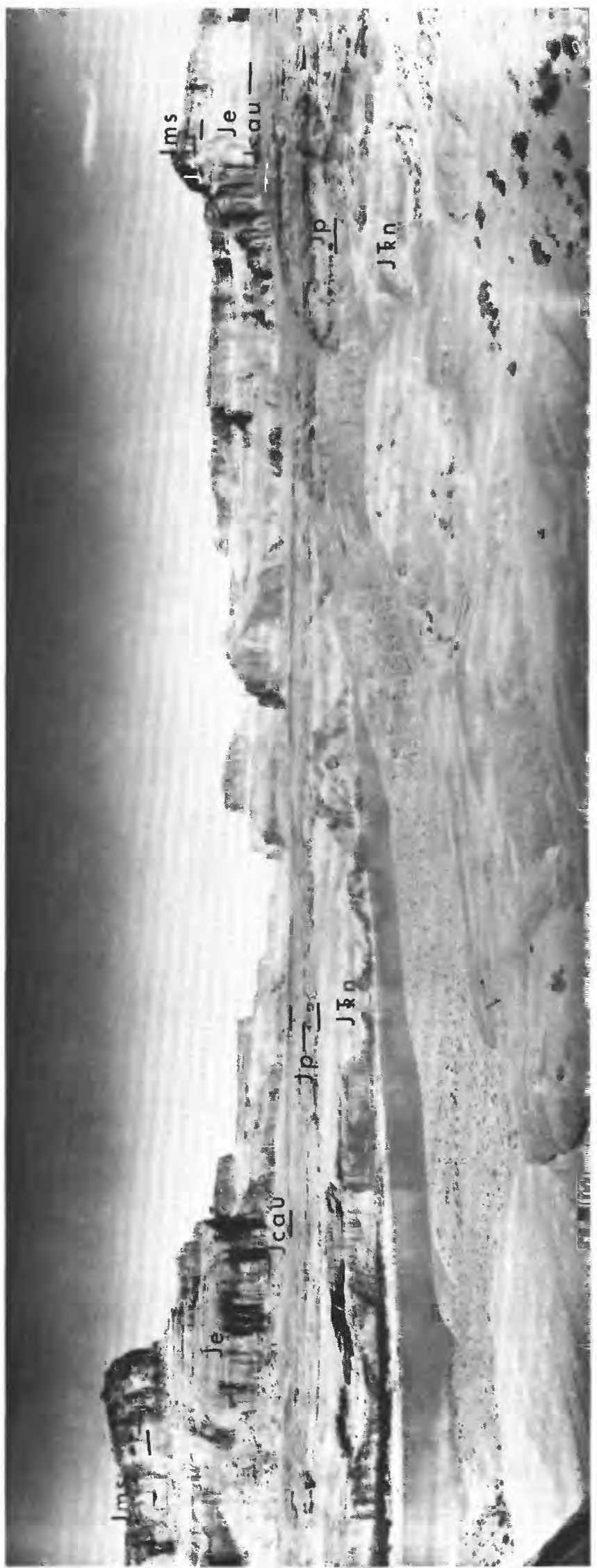

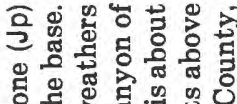

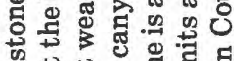

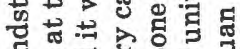

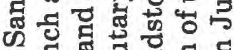
듕

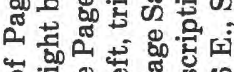
\%

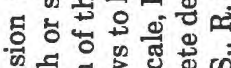
密过

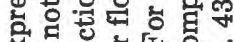

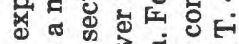

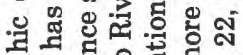

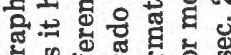

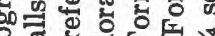
응

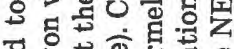

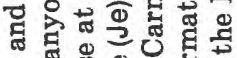
\% 융

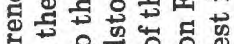

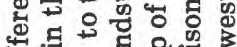

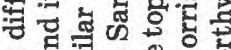

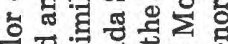
啳

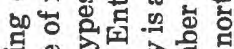

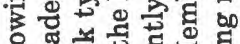

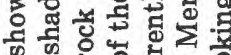
년

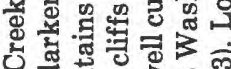
\& 政 ठํำ 范

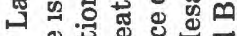

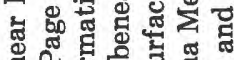
吃

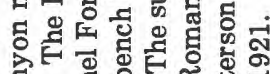

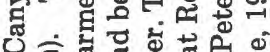
员 0 .

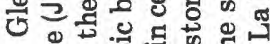
品

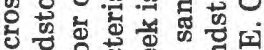

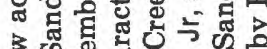

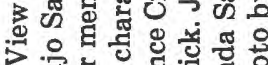
>늉

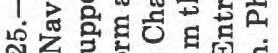

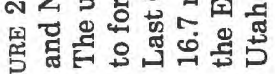
点 


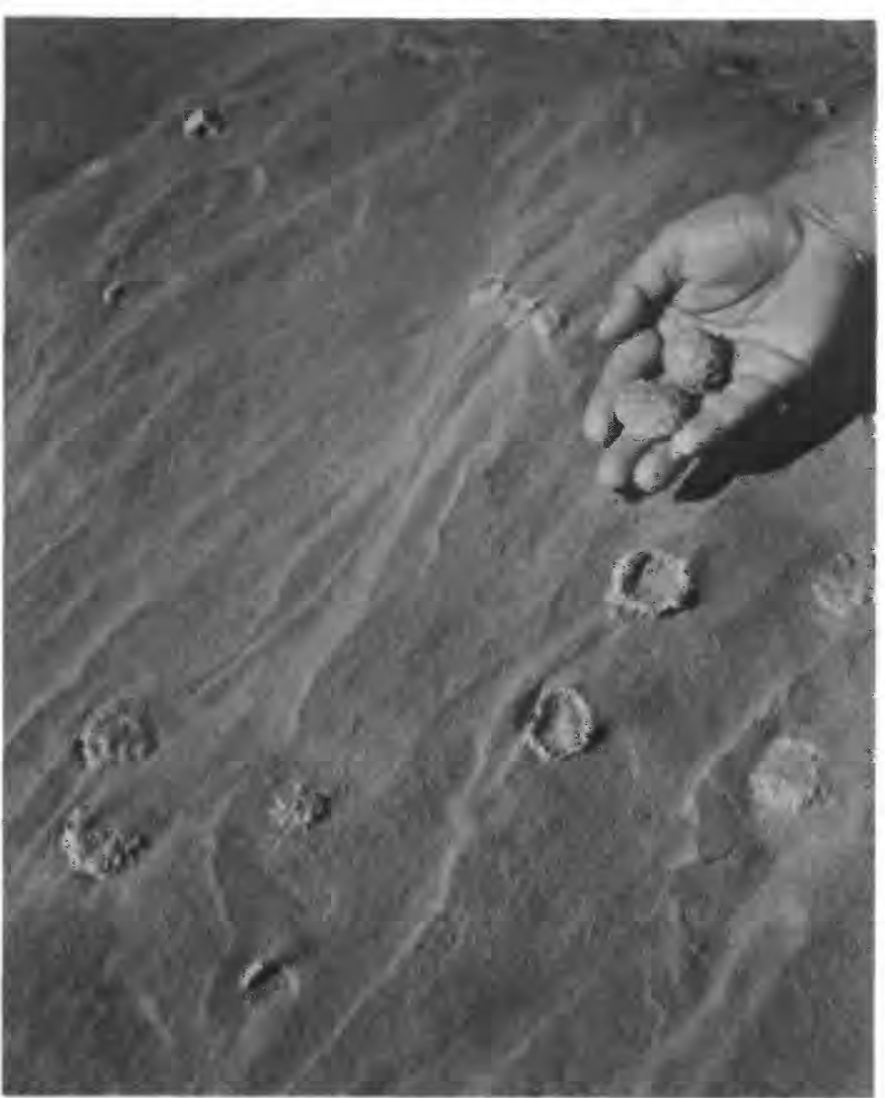

FIGURE 26.-Small nodules in uppermost part of Navajo Sandstone near Page, Ariz. The nodules are about 1.3-2.5 cm in diameter and are cemented mainly with silica in the form of a spherical shell. They commonly occur in the bleached or discolored zone at the top of the Navajo. Type section of Page Sandstone on northwest side of Manson Mesa near Glen Canyon Dam, Coconino County, Ariz.

pinches out underground about 5-10 km west of there. The Harris Wash is as much as $26.8 \mathrm{~m}$ thick on the south side of the Kaiparowits Plateau about $21 \mathrm{~km}$ northwest of Page, Ariz. It thins irregularly westward from there and pinches out near the East Kaibab monocline about $45 \mathrm{~km}$ northwest of Page. Because the younger Thousand Pockets Tongue thins and pinches out northward in the Carmel Formation along the Waterpocket Fold, the Harris Wash probably is the only part of the Page Sandstone that is present in the San Rafael Swell 110-190 km north of the Kaiparowits Plateau (Pipiringos and O'Sullivan, 1975). Subsurface configuration of the tongue cannot be determined accurately owing to the similar response of it and the Navajo Sandstone on the various geophysical welllogging devices.

The Harris Wash Tongue consists predominantly of crossbedded sandstone like most of the other parts of the Page Sandstone. The sandstone is very fine to fine grained and moderately well sorted to well sorted, and the color ranges from very light gray to moderate reddish brown or grayish red. Bedding generally consists of tabular-planar to wedge-planar sets of small- to large-scale cross-stratification as much as $10.7 \mathrm{~m}$ thick. Some interfingering with the Judd Hollow Tongue of the Carmel Formation occurs in the westernmost extent of the Harris Wash. In this area the crossbedding tends to occur in thinner sets less than about a meter thick, and several very thin to thinbedded and ripple cross-laminated strata are also present. Scattered along the base of the Harris Wash are the same angular chert pebbles, generally less than 13 $\mathrm{mm}$ long, that occur so commonly along the base of the main body of the Page. The basal contact is the J-2 unconformity that was described more thoroughly in the preceding discussion of the Page Sandstone.

\section{THOUSAND POCKETS TONGUE}

The Thousand Pockets Tongue of the Page Sandstone is a cliff-forming sandstone unit that is only present in south-central Utah and a small part of northcentral Arizona about $24 \mathrm{~km}$ west of Page, Ariz. (figs. $13,14,15)$. It lies beneath the gypsiferous member or upper member of the Carmel Formation and it is underlain by the Judd Hollow Tongue, limestone member, or banded member of the Carmel. The Thousand Pockets was formerly considered a tongue of the Navajo Sandstone by Phoenix (1963), Wright and Dickey (1963a), and Thompson and Stokes (1970), but it is here designated as a tongue of the Page Sandstone.

The greatest known thickness of the Thousand Pockets is $76.8 \mathrm{~m}$, measured by J. C. Wright and D. D. Dickey (Phoenix, 1963, p. 65-66) in southern Utah about $42 \mathrm{~km}$ northwest of Page, Ariz. The tongue pinches out farther northwest along a northeast-trending line that passes $2 \mathrm{~km}$ southeast of Cannonville, Utah. The tongue also pinches out northward along the Waterpocket Fold and in the subsurface just northeast of that flexure.

The Thousand Pockets Tongue is composed chiefly of crossbedded sandstone that is identical in most aspects to that of the main body of the Page Sandstone. However, the color of the tongue is somewhat more varied than the main body of the Page, ranging from moderate reddish brown, moderate pink, and very light gray throughout most of the region to grayish orange in the area south and southwest of Cannonville, Utah. For the most part, the tongue consists of fine-grained, well-sorted, crossbedded sandstone like that described at the type section of the Page. In its northwesternmost parts where it interfingers with the banded member of the Carmel Formation, the Thousand Pockets grades into very thin to thick-bedded, 


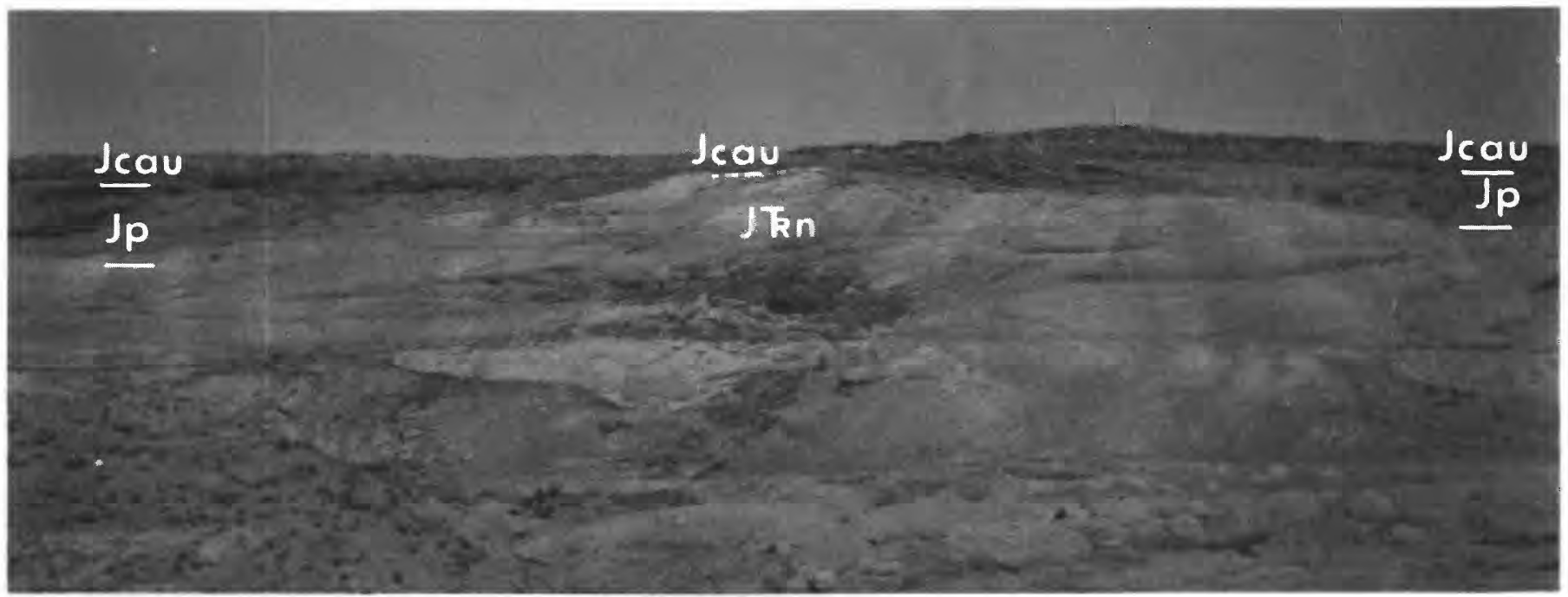

FIGURE 27.-Buried hill of Navajo Sandstone on northeast side of Kaiparowits Plateau. Page Sandstone (Jp) is 11.3 and $7.0 \mathrm{~m}$ thick, respectively, on left and right sides of the buried hill of Navajo Sandstone (JKn), and the upper member of the Carmel Formation (Jcau) rests directly on the crest of the hill in the center of the view. Abundant and relatively large angular chert pebbles occur on the crest and flanks of this hill (fig. 21), suggesting that it was originally capped with a cherty limestone bed of the Navajo. This hill and three other buried hills that have been found in the region indicate that a moderate amount of erosional relief was present on top of the Navajo before and during deposition of the Page.-Note the distinctly lighter color of the Navajo compared to the Page. Cave Point area, looking northwest in the NW1/4 sec. 35, T. 40 S., R. 8 E., Kane County, Utah.

grayish-orange sandstone, and only one or two sets of medium- to large-scale tabular-planar or wedge-planar crossbedding are present (figs. 13, 14).

Throughout most of the region east of Cannonville, Utah, a conspicuous notch-forming red sandstone or silty sandstone marker bed is present in the middle of the Thousand Pockets Tongue (fig. 15). This bed is as much as $3.7 \mathrm{~m}$ thick and is composed of very fine to fine-grained, moderately sorted, very thin to thinbedded sandstone and silty sandstone. Although the marker bed has a lensoid shape in the outcrop belts around the Kaiparowits Plateau (figs. 10, 11), its lithologic similarity to the banded and upper members of the Carmel Formation suggests that it may be a thin tongue of either or both of these members.

The basal contact of the Thousand Pockets Tongue generally is sharp and planar, although in the northwesternmost parts of the tongue the lower contact locally is gradational. Contrary to Thompson and Stokes (1970), no evidence was found that this surface is an unconformity.

\section{ENTRADA SANDSTONE}

The Entrada Sandstone was named by Gilluly and Reeside (1928) for exposures at Entrada Point in the northeastern part of the San Rafael Swell of central Utah. Subsequent workers, notably Wright and Dickey (1963b), correlated the formation southward into the Kaiparowits Plateau of south-central Utah. In the Kaiparowits Plateau the Entrada is divided into three members (Peterson, 1973; Zeller, 1973), of which only the lower member is considered here.

The lower member of the Entrada is approximately 107-152 m thick and consists of two facies. Southeast of a line that passes roughly through Cannonville and Escalante, Utah, it consists predominantly of a crossbedded sandstone facies; northwest of that line it consists of a generally flat bedded silty sandstone facies. The crossbedded southeastern facies is composed of very fine to fine-grained, moderately to wellsorted, moderate-reddish-orange, cliff-forming sandstone (figs. 16, 25, 29). The bedding consists of tabularplanar and wedge-planar sets of medium- to largescale, low- and high-angle cross-strata. The flat-bedded northwestern facies is moderate reddish orange and composed of coarse siltstone and fine-grained, moderately to poorly sorted, slope-forming silty sandstone (fig. 15). The bedding in this facies ranges from very thin bedded to very thick bedded.

The lower contact of the southeastern facies is sharp and is placed at the top of the highest thin-bedded silty sandstone or mudstone of the underlying upper member of the Carmel Formation. Interfingering of the lower $1.8 \mathrm{~m}$ of the Entrada with the upper part of the Carmel was found in the Kane Wash area about $23 \mathrm{~km}$ northeast of Page, Ariz. The lower contact of the northwestern facies is somewhat more difficult to pick owing to lithologic similarity of the Entrada and 


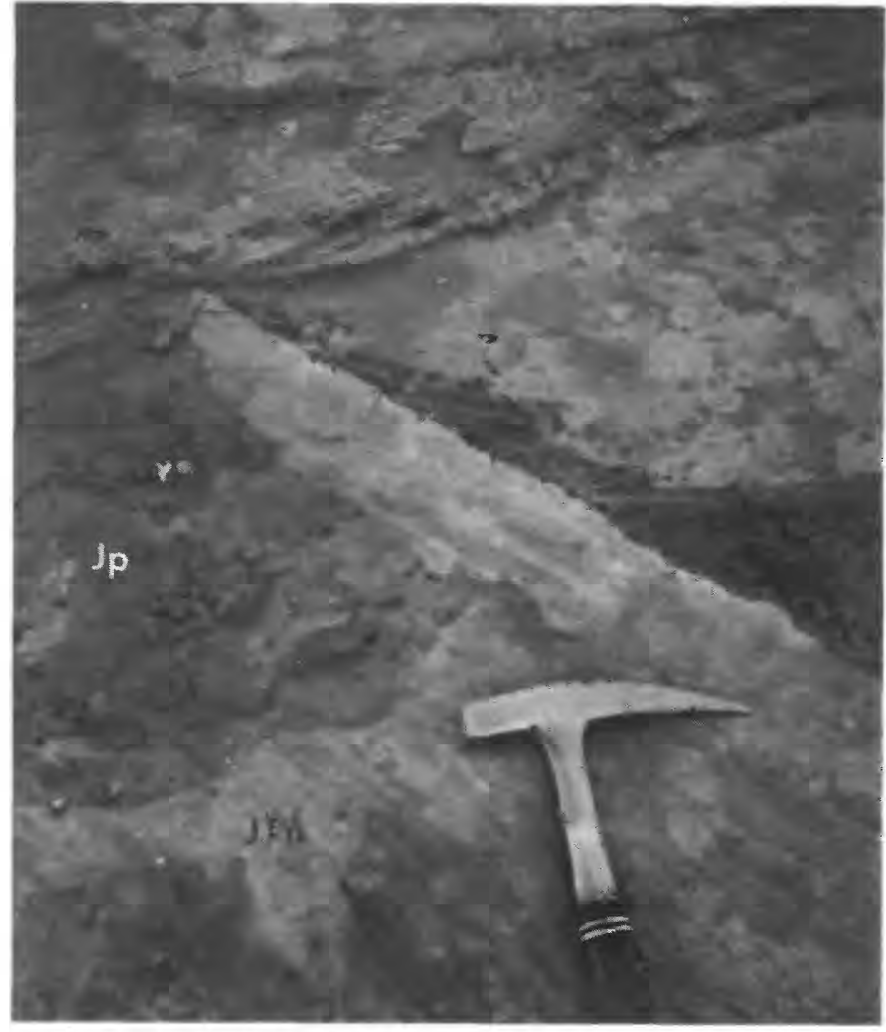

FIGURE 28.-Small buried ledge of Navajo Sandstone (Jk n) preserved beneath Page Sandstone (Jp) on northeast side of Kaiparowits Plateau. Small angular white chert pebbles are scattered along the J-2 unconformity just left of the pick. This ledge, and similar features occurring elsewhere in the region, indicate that the top of the Navajo was not beveled to a planar surface prior to deposition of the Page. Pick is scaled in inches. West side of Hurricane Wash at measured section 39 , Kane County, Utah.

underlying Carmel. Southwest of Cannonville, the contact is placed at the top of the highest gypsum or mudstone bed of the Carmel or at the top of the highest thin, white, hard, calcareous sandstone bed in the marker zone at the top of the upper member or Winsor Member of the Carmel. Some interfingering of the Entrada and the Carmel probably occurs in this area, but it could not be documented owing to the large amount of soil and vegetation cover. Near Escalante, the contact is placed at the top of a thin purple mudstone or bentonite marker bed. Where this bed cannot be recognized, owing to soil cover, the contact is at the top of the highest gypsum bed in the Carmel.

\section{AGE AND CORRELATION}

\section{GLEN CANYON GROUP}

Although the Glen Canyon Group lies between welldated Upper Triassic and Middle Jurassic strata, the paleontological evidence previously obtained from it was not sufficiently diagnostic to determine where the
Triassic-Jurassic boundary is within the group. New findings strongly suggest that most of the group is Early Jurassic in age and that the systemic boundary is considerably lower than had been thought by previous workers (Lewis and others, 1963; Galton, 1971). Because the newly discovered fossils are still being studied, previous age assignments of formations and members in the group are retained by the U.S. Geological Survey until a more thorough evaluation of the fossils can be published. The new paleontological evidence that the group is entirely Early Jurassic in age in southwestern Utah and northwestern Arizona comes from the recent discovery of Early Jurassic palynomorphs in the Whitmore Point Member of the Moenave Formation. The fossils came from samples collected by C. E. Turner-Peterson and Fred Peterson from the lower part of the Whitmore Point Member at Whitmore Point, Ariz., about $32 \mathrm{~km}$ southwest of Kanab, Utah (fig. 1).

The palynomorphs were identified by Bruce Cornet of Gulf Research and Development Company. He stated (written commun., 1976):

The samples are strongly dominated by species of Corollina, which make up about 95 to 99 percent of the assemblage. The dominant species is Corollina torosus (Reissinger) Klaus; C. murphyi Cornet and Traverse, and C. meyeriana (Klaus) Venkatachala and Góczán are also present, but are rare. Other rare species include: Granulatisporites infirmus (Balme) Cornet and Traverse, Todisporites rotundiformis (Malyavkina) Pocock, Cycadopites spp., and possibly Podocarpidites sp.

Preservation is good. Tetrads of Corollina are common and indicate little abrasion during transport. In addition, one of the samples contains "ghosts" of possible reworked Triassic bisaccates, such as Pityosporites and Abiespollenites, which are normally characteristic of the Chinle Formation. The difference in preservation between these "ghosts" and the indigenous palynoflora is considerable.

The strong dominance of the palynoflorules by species of Corollina is characteristic of the Liassic (Lower Jurassic) Series. In addition, comparison with palynoflorules obtained from the Portland Formation at the top of the Newark Group in the Hartford basin of the Connecticut Valley in the eastern United States (Cornet, Traverse, and McDonald, 1973; Cornet and Traverse, 1975) suggests a further refinement in the age. Within the Portland Formation there is a trend from almost entirely non-striate to 28 percent pseudostriate forms of Corollina torosus in the lower part of the formation to 17-43 percent striate and pseudostriate forms in the upper-lower to lower-middle part and to about $35-76$ percent striate and pseudostriate forms in the middle part of the Portland. If such a trend reflects major regional climatic changes and evolution in North America, then the composition of the Whitmore Point palynoflorules, with $35-42$ percent striate and pseudostriate forms of $C$. torosus, suggests correlation with the upper-lower to lowermiddle part of the Portland Formation, which is late Sinemurian to early Pliensbachian in age.

Recently, Bruce Cornet (oral commun., 1977) tentatively identified three other palynomorphs from the Whitmore Point Member that support these age determinations; they are Corollina cf. C. itunensis (Pocock), Chasmatosporites cf. C. apertus (Rogalska) Nilsson, 
and cf. Callialasporites. As presently understood, the oldest known occurrence of these fossils is from the Liassic (Lower Jurassic) Series. C. itunensis ranges down into middle Liassic strata whereas $C$. apertus ranges further down into basal Liassic rocks. In most areas, Callialasporites is found in middle Liassic and younger strata although it has been found in lower Liassic beds in Spain; it has been reported from uppermost Triassic (Rhaetian) beds in North Africa but the identification from this area is questioned. Thus, the oldest presently known age of these fossils suggests a middle Liassic (middle Early Jurassic) age for the
Whitmore Point Member of the Moenave Formation. Because the underlying Dinosaur Canyon Sandstone Member and the overlying Springdale Sandstone Member of the Moenave are closely related and not separated from the Whitmore Point by unconformities, all three members and the entire Moenave Formation probably fall in the Lower Jurassic Series (fig. 30).

It should be noted that subsequent to his most recent publication dealing with the Early Jurassic age of the Portland Formation (Cornet and Traverse, 1975), Bruce Cornet is now able to place the Triassic-Jurassic

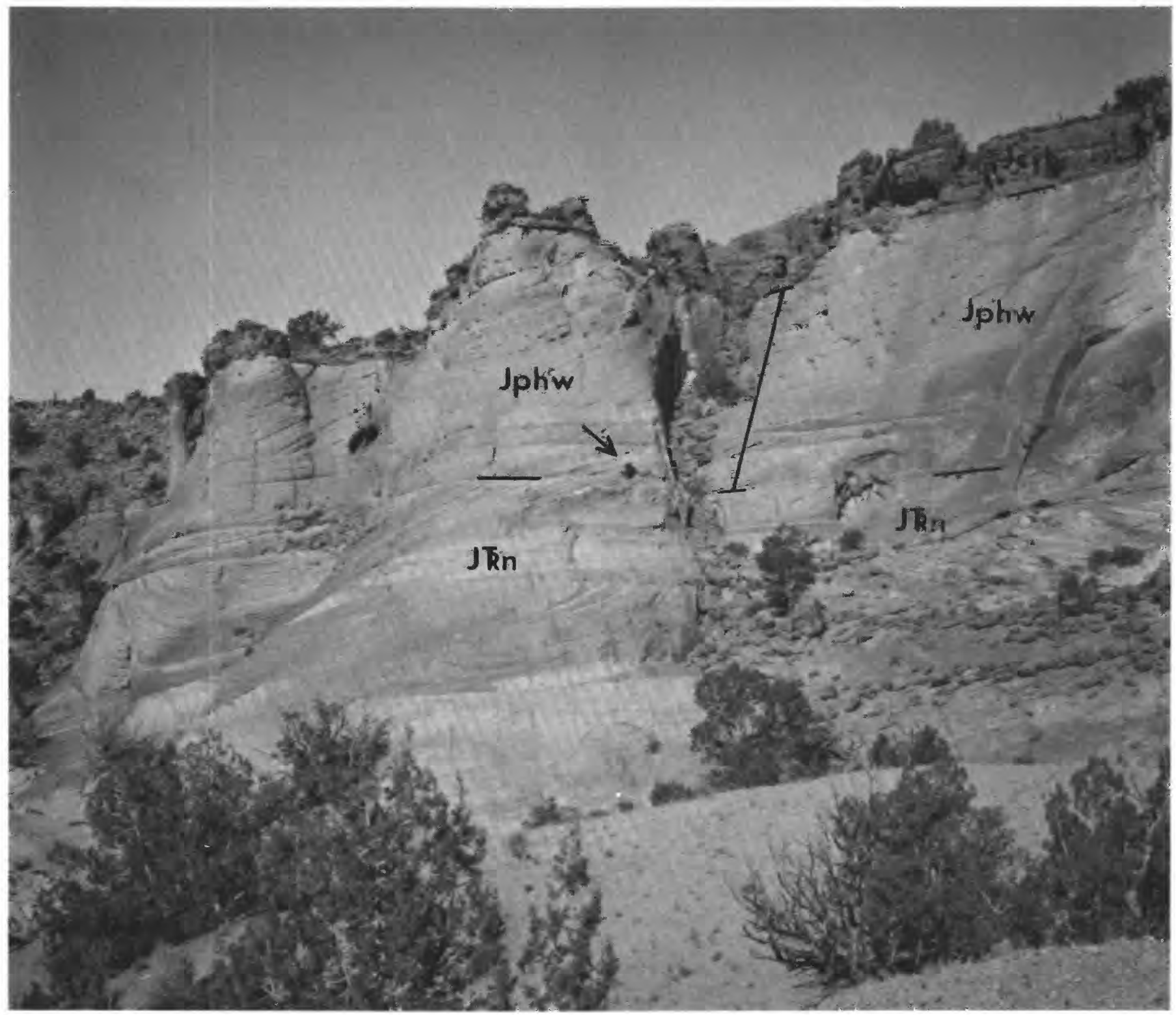

FIgURE 29.-Type section of Harris Wash Tongue of Page Sandstone. View is toward the west in Halfway Hollow near its junction with Harris Wash, about $20 \mathrm{~km}$ southeast of Escalante, Utah. 3, type measured section; the tongue is $18.3 \mathrm{~m}$ thick. Although not apparent from this distance, fossil joint crevices and small angular chert pebbles are well exposed to left of where the man (arrow) is standing. $(\mathrm{J} K \mathrm{n})$, Navajo Sandstone; Jphw, Harris Wash Tongue of Page Sandstone; Jcjh, Judd Hollow Tongue of Carmel Formation. 


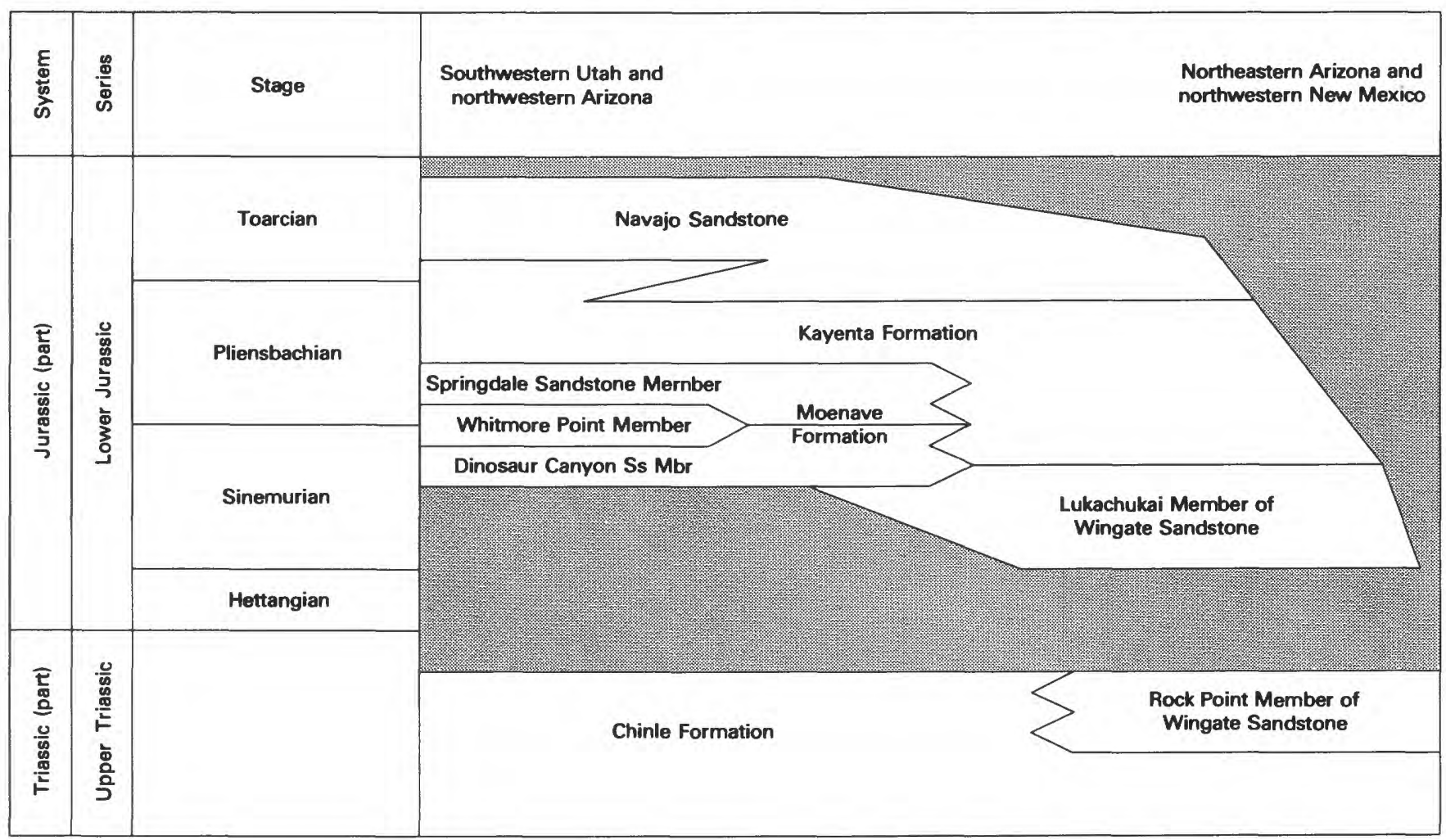

FIGURE 30.-Diagram showing correlation of formations in the Glen Canyon Group (Wingate Sandstone, Moenave Formation, Kayenta Formation, and Navajo Sandstone) with European time-stratigraphic units, based on new fossils found in the Whitmore Point Member of the Moenave Formation. These age assignments are considered tentative and have not been formally adopted by the U.S. Geological Survey. Unconformity indicated by shaded area.

boundary more accurately in the Newark and Hartford-Deerfield basins of Pennsylvania-New Jersey and Connecticut-Massachusetts respectively. According to Bruce Cornet (written commun., 1976):

The new palynological discoveries, as yet unpublished, indicate that the systemic boundary lies about $20-25$ meters $(64-80 \mathrm{ft})$ below the oldest basalt flow in the Newark basin. The basalt flows and interbedded sedimentary rocks of the Newark basin correlate approximately with the basalt flows and interbedded sedimentary rocks of the Talcott Formation in the Hartford basin and with the Deerfield Basalt and overlying lower Turners Falls Sandstone of the Deerfield basin. This is based on palynoflorules, as well as on fish faunas (P. E. Olsen, oral commun., 1976), although the oldest flow in the Newark basin is probably slightly older than the oldest flow in the Talcott Formation of the Hartford basin and the Deerfield Basalt of the Deerfield basin. Thus, the Talcott Formation is early Liassic in age and the younger Portland Formation is middle and late Liassic in age.

These findings indicate that the Portland Formation clearly is of Liassic age, and that a Liassic age is certainly indicated for the Glen Canyon Group (above the Rock Point Member of the Wingate Sandstone) which correlates with the Portland.

In addition to the palynomorphs, reevaluation of the vertebrates also supports correlation of the Glen Canyon Group above the Rock Point Member of the
Wingate with the Portland Formation of the eastern United States (Walker, 1968; Galton, 1971, Olsen and Galton, 1977). Based on the fossils and correlations, we consider the Kayenta Formation and Navajo Sandstone Early Jurassic in age. Since the palynoflorules from the Moenave Formation indicate a late Sinemurian to early Pliensbachian age, and the oldest beds of the San Rafael Group are early Bajocian in age (earliest Middle Jurassic), the Kayenta and Navajo probably were deposited during the Pliensbachian and Toarcian Ages of the Early Jurassic Epoch (fig. 30).

Throughout much of the Colorado Plateau east of southwestern Utah and northwestern Arizona, beds older than the Moenave Formation are present at the base of the Glen Canyon Group. In this area, the Wingate Sandstone lies beneath the Moenave or Kayenta Formation (fig. 2). The Wingate is divided into two members: the Lukachukai Member at the top is widespread and occurs throughout much of the Colorado Plateau, whereas the underlying Rock Point Member is more restricted in distribution and occurs primarily in northeastern Arizona and northwestern New Mexico (Harshbarger and others, 1957). Where the Lukachukai is the basal member of the Wingate, 
most workers agree that it is separated from the underlying Chinle Formation by an unconformity (Wilson, 1974), termed the J-0 unconformity by Pipiringos and O'Sullivan (1978). Thaden, Trites, and Finnell $(1964$, p. $69-70)$ reported intertonguing of the Lukachukai and Chinle at two places in the White Canyon area of southeastern Utah, but the beds were walked out at these localities and it was found that the intertonguing does not exist. Because the Lower Jurassic Moenave Formation interfingers with the uppermost beds of the Lukachukai Member (Harshbarger and others, 1957), we place the systemic boundary at the J-0 unconformity at the base of the Lukachukai, and this suggests an Early Jurassic age for the Lukachukai Member of the Wingate Sandstone. Interfingering with the basal beds of the Moenave Formation indicates that the Lukachukai Member of the Wingate is only slightly older than the Moenave, and that the Lukachukai Member probably is early Sinemurian in age (fig. 30 ).

Interfingering of the Lukachukai and Rock Point Members of the Wingate Sandstone has been reported in northeastern Arizona and northwestern New Mexico (Harshbarger and others, 1957; Wilson, 1974), but it could not be confirmed by field investigations. This contact was examined by M. W. Green, R. B. O'Sullivan, Fred Peterson, and G. N. Pipiringos and it was found that interfingering of these members cannot be demonstrated. Instead of interfingering, we suggest that the same J-0 unconformity that separates the Lukachukai Member of the Wingate from the Upper Triassic Chinle Formation in other areas separates the Lukachukai and Rock Point Members of the Wingate in northeastern Arizona and northwestern New Mexico. Because the Rock Point Member contains phytosaur teeth which indicate a Late Triassic age (Harshbarger and others, 1957 , p. 10), we place the Triassic-Jurassic boundary at the top of the Rock Point Member (fig. 30) and we suggest a Late Triassic and Early Jurassic age for the Wingate Sandstone wherever it contains the Rock Point Member. In southeastern Utah and southwestern Colorado, where the Rock Point Member is not present, the Wingate Sandstone consists solely of the Lukachukai Member. In these areas, the Wingate, like the Lukachukai Member, is considered Early Jurassic in age.

These suggestions of new age assignments for units in the Glen Canyon Group also affect other unfossiliferous units that correlate with the group and cannot be dated by other means. The Aztec Sandstone of southern Nevada and southeastern California is a correlative of the Navajo Sandstone (McKee and others, 1956; Wilson and Stewart, 1967), which we now consider Early Jurassic in age. For this reason, the
Aztec Sandstone probably is Early Jurassic in age. The Glen Canyon Sandstone and Nugget Sandstone of southwestern Wyoming, northern Utah, and northwestern Colorado also correlate with the Glen Canyon Group (excluding the Rock Point Member of the Wingate Sandstone; Poole and Stewart, 1964). For this reason we consider the Glen Canyon Sandstone and Nugget Sandstone Early Jurassic in age. As noted earlier, these age designations are considered tentative by the U.S. Geological Survey and have not been formally adopted by the U.S. Geological Survey.

Correlation with western Nevada formations can be inferred from the age of the formations, but it is not known if the correlative strata were physically connected across eastern Nevada at the time of deposition. The Boyer Ranch Formation of western Nevada (Speed and Jones, 1969) has been correlated with the Navajo Sandstone, primarily because both formations consist largely of highly mature quartz sandstone, but this correlation is contradicted by the different ages of these formations. Speed (1976) indicated that the Boyer Ranch probably is late Toarcian and (or) Bajocian, which is younger than the probable Pliensbachian-early Toarcian age of the Navajo (fig. 30 ). We suggest that the Boyer Ranch probably correlates with the Temple Cap Sandstone and (or) the limestone member of the Carmel Formation, and that the Middle Jurassic extrusive rocks that lie on the Boyer Ranch may be closely related in time to the pebbles and cobbles of volcanic material in the Middle Jurassic banded member and Winsor Member of the Carmel Formation. The age designations adopted in this report suggest that the Glen Canyon Group (excluding the Rock Point Member of the Wingate Sandstone) correlates with the Sinemurian, Pliensbachian, and Toarcian parts of the Sunrise and Dunlap Formations of western Nevada.

Although the new paleontological evidence indicates changes in age assignments of units in the Glen Canyon Group and correlative strata, we do not believe it is appropriate to make definitive age changes until the new fossils can be described more thoroughly in a separate publication. For this reason, we are not changing the age assignments adopted earlier by the U.S. Geological Survey (Lewis and others, 1961) for units in the Glen Canyon Group and correlative strata. Thus, the ages presently assigned to the formations discussed previously remain as follows:

Formation

Age

Aztec Sandstone ......... Triassic(?) and Jurassic

Glen Canyon Sandstone.... Late Triassic and Early Jurassic

Wingate Sandstone ........ Late Triassic

Kayenta Formation ....... Late Triassic(?)

Navajo Sandstone ......... Triassic(?) and Jurassic

Moenave Formation ....... Late Triassic(?) 


\section{SAN RAFAEL GROUP}

Although the San Rafael Group is largely unfossiliferous, a Middle Jurassic age can be assigned to it on the basis of fossils in parts of the Carmel Formation and by regional correlations to more fossiliferous strata in the northern part of the Western Interior of the United States. This report only deals with the age of stratigraphic units in the lower part of the group; younger beds are covered in reports by Imlay (1952, 1957, 1979).

The Temple Cap Sandstone is unfossiliferous and, therefore, must be dated by correlation with formations whose ages are known. No other rock units on the Colorado Plateau are known to be equivalent in age to the Temple Cap Sandstone, and the nearest unit with which it can be correlated is the Gypsum Spring Member of the Twin Creek Limestone farther north in northern Utah, southeastern Idaho, and western Wyoming (called the Gypsum Spring Formation in south-central Wyoming). The Temple Cap and Gypsum Spring are thought to correlate because: (1) the upper contact of both is the J-2 unconformity and both units are beveled out in a similar manner by this unconformity, (2) the lower contact of the Gypsum Spring is the J-1 surface that occurs at the base of the Temple Cap, and (3) both contain similar lithologies, although the Temple Cap does not contain the fossiliferous limestone that occurs in the Gypsum Spring. Inasmuch as paleontological evidence indicates the Gypsum Spring is early and early middle Bajocian in age, according to R. W. Imlay (written commun., 1974), the Temple Cap is also assigned an early and early middle Bajocian age here (fig. 31).

The limestone member of the Carmel Formation is fairly fossiliferous in southwestern Utah: the faunule obtained from it consists mostly of pelecypods, but also includes gastropods, echinoids, worm tubes, and colonial corals (Imlay, 1964). According to Imlay (oral

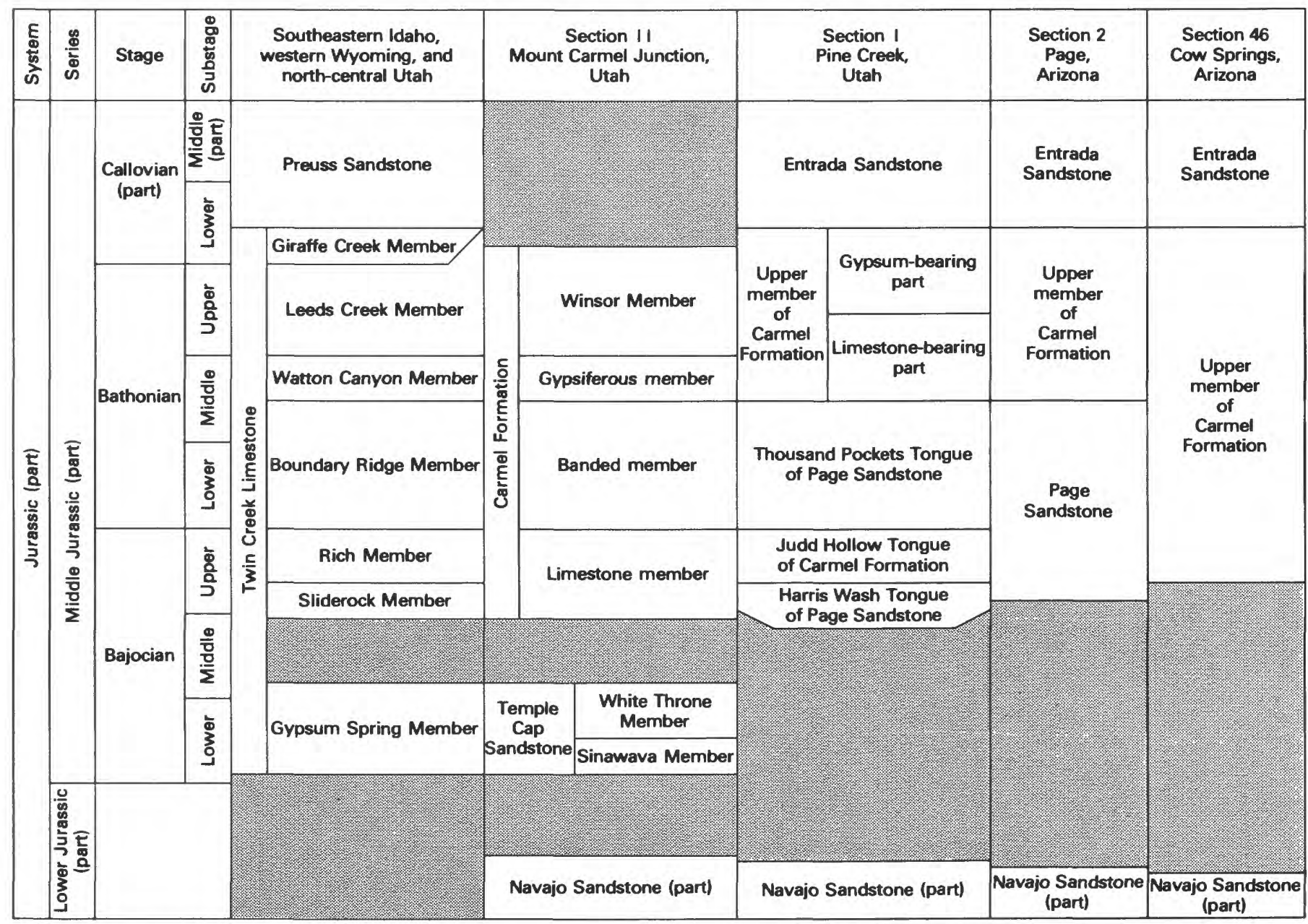

FIGURE 31.-Correlation of rocks at selected sections in southwestern Utah and north-central Arizona with a section in southeastern Idaho, western Wyoming, and north-central Utah (Imlay, 1967, and written commun., 1975). Unconformities indicated by shaded areas. 
commun., 1974), the fossils indicate that the limestone member is late-middle and late Bajocian in age (fig. 31) and that it correlates with the Sliderock and Rich Members of the Twin Creek Limestone in the Wyoming-Idaho-Utah area.

Carmel strata above the limestone member are unfossiliferous or, in the case of the gypsiferous member, contain a depauperate and nondiagnostic fauna. Based on a regional synthesis and similar stratigraphic position, the present writers agree with Imlay's (1967) correlation of the banded and gypsiferous members of the Carmel with the Boundary Ridge and Watton Canyon Members, respectively, of the Twin Creek Limestone as well as correlation of the Winsor Member of the Carmel with the Leeds Creek and Giraffe Creek Members of the Twin Creek. Inasmuch as Imlay (written commun., 1974) has placed the BathonianCallovian boundary at the base of the Giraffe Creek Member of the Twin Creek or equivalent strata, these correlations indicate that the banded and gypsiferous members and the lower part of the Winsor Member are Bathonian in age and the uppermost part of the Winsor Member is early Callovian in age (fig. 31).

The stratigraphic relations in south-central Utah indicate that the Judd Hollow Tongue of the Carmel correlates with the limestone member farther west, thus indicating a late-middle and late Bajocian age for the Judd Hollow. Because the Page Sandstone is laterally equivalent to the Judd Hollow Tongue and banded member of the Carmel Formation, the Page also is latemiddle Bajocian to early-middle Bathonian (Middle Jurassic) in age. Accordingly, the Harris Wash Tongue of the Page is late-middle and late Bajocian in age because it lies beneath but in normal depositional contact with the Judd Hollow Tongue of the Carmel, and the Thousand Pockets Tongue of the Page is early to early-middle Bathonian in age because it is laterally equivalent to the banded member of the Carmel as shown diagrammatically on figure 31 .

Although the upper member of the Carmel is middle Bathonian to early Callovian in age near Cannonville and Escalante, Utah, where it correlates with the gypsiferous member and Winsor Member of the Carmel, the lowermost part of the upper member is older farther southeast, where it interfingers with the uppermost beds of the Page Sandstone northeast of Page, Ariz. (fig. 10). In Glen Canyon, roughly $50 \mathrm{~km}$ northeast of Page, Ariz., and farther southeast, wherever it lies directly on the Navajo Sandstone, the upper member is late Bajocian, Bathonian, and early Callovian in age (fig. 31).
According to Imlay (1967, p. 20), the entire Entrada Sandstone is late-early and middle Callovian in age.

\section{NAME AND LOCATION OF MEASURED SECTIONS}

Accurate locations of measured sections are given wherever possible, but, in general, the locations of measured sections of formations in the Glen Canyon Group are only approximately known. Sections of formations in the Glen Canyon Group are included with the nearest section of formations in the San Rafael Group to avoid repetition. References are given where measured by persons other than the writers.
Location and reference

No. Name

1. Pine
2. Page

SW $1 / 2$ sec. $29, \mathrm{SE}^{1 / 4} \mathrm{sec}$ se, T. 34 S., R. 3 E., Garfield County, Utah.

3. Harris Wash

Sec. 2a: SW1/4 sec. $1, \mathrm{SE}^{1 / 4} / 4$ sec. 2, T. 41 N., R. 8 E.; Sec. 2 b: NW $1 / 4$ sec. 19 , T. 41 N., R. 9 E., Coconino County, Ariz. NW1/4 sec. 35 , T. 35 S., R. 4 E.; SE $1 / 4$ sec. 22, NE $1 / 4$ sec. 26 , T. 36 S., R. 4 E., Garfield County, Utah.

4. Zion Canyon

NW1/4 sec. 2, T. 41 S., R. 10 W., Washington County, Utah. Glen Canyon Group measured nearby in Zion Canyon by Wilson $(1965$, p. 32,38 , sec. 2$)$.

5. Gunlock

NW1/4 sec. 32, T. 40 S., R. 17 W., Washington County, Utah.

6. Diamond Valley About sec. 2, T. 41 S., R. 16 W., Washington County, Utah (Reeside and Bassler, 1922, p. 77, sec. 21).

7. Cottonwood Canyon NE1/4 sec. 11, T. 41 S., R. 15 W., Washington County, Utah (J. C. Wright, unpub. data).

8. Danish Ranch

9. Potato Hollow

NE $1 / 4$ sec. 34, T. 40 S., R. 14 W., Washington County, Utah.

10. Meadow Creek Sec. 7, T. 41 S., R. 8 W.; E1/2 sec. 13 , SW $1 / 4$ sec. 16, T. 41 S., R. 9 W., Kane County, Utah.

11. Mount Carmel Junction

12. Kanab Creek

13. Brown Canyon

14. Johnson Canyon
Secs. 12, 13, 24, 25, T. 41 S., R. 8 W., Kane County, Utah; Carmel Formation from Gregory and Moore (1931, p.73-74) modified by Gregory (1950a, p. 126-127, sec. 13) and Cashion (1967). Temple Cap Sandstone measured in NE1/4 sec. 36, T. 41 S., R. $8 \mathrm{~W}$. by Fred Peterson in 1970. Glen Canyon Group measured about $8 \mathrm{~km}$ west of Kanab by Wilson (1965, p. 32, 38 , sec. 3 ).

NW $1 / 4$ sec. 16, T. 41 S., R. 6 W., Kane County, Utah.

NW1/4 sec. 32 , T. 40 S., R. 5 W.; SE $1 / 4$ sec. $7, N^{1} / 2$ sec. $19, N^{1 / 1} / 4$ sec. $21, T .41$ S., R. 5 W., Kane County, Utah.

NW $1 / 4$ sec. 26 , T. 41 S., R. 5 W., Kane County, Utah. 
No. Name

15. Carly Knoll

16. Lick Wash

17. Little Bull Valley

18. Averett Canyon

19. Sheep Creek

20. Kodachrome Flat

21. The Gut

22. Goodwater Seep

23. Hackberry Canyon

24. West Cove

25. East Cove

26. Judd Hollow

27. Sand Valley

28. Gunsight Butte

\section{Location and reference}

$W^{1} 1 / 2$ sec. 30 , center of sec. 31 , T. 40 S., R. 4 W.; SE $1 / 4$ sec. 21 , T. 40 S., R. $4 \frac{1 / 2}{2}$ W.; SW1/4 sec. 3, SE1/4 sec. 4, T. 41 S., R. 41/2 W., Kane County, Utah.

SW $1 / 4$ sec. 30 , T. 39 S., R. 3 W.; NE $1 / 4$ sec. 1, T. 40 S., R. 4 W., Kane County, Utah.

$\mathrm{SE}^{1 / 4}, \mathrm{NW}^{1 / 4}$ sec. $19, \mathrm{SE}^{1 / 4}$ sec. $20, \mathrm{NE}^{1 / 4}$ sec. 28, T. 38 S., R. 3 W., Kane County, Utah.

NE $1 / 4$ sec. 23, T. 38 S., R. 3 W., Kane County, Utah.

Center of sec. 24, T. 38 S., R. 3 W., Kane County, Utah.

$E^{1 / 2}$ sec. $3, W^{1 / 2}$ sec. $14, S^{1 / 4}$ sec. 15 , $\mathrm{SW}^{1 / 4}$ sec. $20, \mathrm{SW}^{1 / 4}$ sec. $21, \mathrm{E}^{1 / 2}$ sec. 22, T. 38 S., R. 2 W., Kane County, Utah.

$\mathrm{SE}^{1 / 4} 4$ sec. 12 , T. 39 S., R. 1 W., Kane County, Utah.

$\mathrm{SE}^{1 / 4} 4$ sec. 11 , T. 40 S., R. 1 W., Kane County, Utah (J. C. Wright, unpub. data).

$\mathrm{SE}^{1 / 4} 4$ sec. 9, T. 41 S., R. 1 W., Kane County, Utah (J. C. Wright, unpub. data).

SW11/4 sec. 19, T. 42 S., R. 1 W.; $\mathrm{SE}^{1 / 4} 4$ sec. 25, T. 42 S., R. 2 W., Kane County, Utah.

NE $1 / 4$ sec. 15 , T. 43 S., R. 1 W., Kane County, Utah.

Phoenix, 1963, sec. 2, p. 64-66, modified.

Center of $W^{1 / 2}$ sec. 36, T. 43 S., R. 1 E., Kane County, Utah.

Note: According to Phoenix (1963, p. 67), the type section of the Judd Hollow Tongue and Thousand Pockets Tongue is about $1 \mathrm{~km}$ northeast of this locality. However, judging from the distribution of outcrops in the area, and a photo of the locality in the original report (Phoenix, 1963, p. 32, fig. 12), the type sections probably were measured here. Remeasured by Fred Peterson in 1970.

SE $1 / 4$ sec. 33, SW1/4 sec. 34, T. 42 N., R. 7 E., Coconino County, Ariz.

Navajo Sandstone measured about 29.9 km northwest of Lees Ferry by Phoenix $(1963$, p. 30).

Kayenta and Moenave Formations measured in the NE $1 / 4$ sec. $19, \mathrm{~T} .40 \mathrm{~N}$., R. 8 E., Coconino County, Ariz. by Phoenix (1963, p. 79-80, sec. 7).

Wingate Sandstone probably measured in same area as Kayenta Formation by Wilson $(1965$, p. 38).

SW $1 / 4$ sec. 23, T. 43 S., R. 5 E., Kane County; W1 $1 / 2$ sec. 12, T. 44 S., R. 5 E., San Juan County, Utah.
No. Name

29. Kane Wash

Location and reference

$\mathrm{NE}^{1 / 4} 4$ sec. 13 , T. 43 S., R. 5 E.; NW $1 / 4$ sec. 18, T. 43 S., R. 6 E., Kane County, Utah. D. D. Dickey and others (unpub. data).

30. Cummings Mesa NW Measured at north end of west finger of Cummings Mesa, about $5.5 \mathrm{~km} \mathrm{~N} .55^{\circ}$ E. and $6.9 \mathrm{~km} \mathrm{~N} .62^{\circ} \mathrm{E}$. of Gregory Butte, San Juan County, Utah.

31. West Canyon

Measured $9.2 \mathrm{~km} \mathrm{~S} .55^{\circ} \mathrm{E}$. of Gregory Butte, San Juan County, Utah, and $10.9 \mathrm{~km} \mathrm{~S} .55^{\circ} \mathrm{E}$. of Gregory Butte, Coconino County, Ariz.

32. Cummings Mesa trail

33. Upper Valley

34. Seep Flat

35. Twentyfive Mile Wash

36. Early Weed Bench

37. Cat Pasture

38. Big Hollow Wash

39. Hurricane Wash

40. Cave Point

41. Fiftymile Point

42. Navajo Point

43. Little Arch Canyon

44. Tsai Skizzi

45. Square Butte

46. Cow Springs Measured on southeast side of Cummings Mesa about $10.5 \mathrm{~km} \mathrm{~N} .6^{\circ} \mathrm{E}$. of High Point Rock, Coconino County, Ariz.

Well: California Company, No. 1 unit, $\mathrm{SW}^{1 / 4} \mathrm{NW}^{1 / 4} 4$ sec. 12 , T. 36 S., R. 1 E., Garfield County, Utah.

SW1/4 sec. 33, T. 36 S., R. 5 E.; N1/2 sec. 4, T. 37 S., R. 5 E., Garfield County, Utah.

W1/2 sec. 30 , T. 37 S., R. 6 E., Garfield County, Utah.

NW1/4 SE $1 / 4$ sec. 1, T. 38 S., R. 6 E., Kane County, Utah.

$N^{1 / 4}$ sec. 26, NE $1 / 4$ sec. 27 , T. 38 S., R. 6 E., Kane County, Utah.

Center of $\mathrm{N}^{1 / 2} \mathrm{sec}$. 7, SW1/4 sec. 10, T. 39 S., R. 7 E., Kane County, Utah.

$\mathrm{NE}^{1 / 4}$ sec. 26, T. 39 S., R. 7 E., Kane County, Utah.

SW $1 / 1 / 4$ sec. 26 , T. 40 S., R. 8 E.; NE1/4 sec. 2, T. 41 S., R. 8 E., Kane County, Utah.

NW $1 / 4$ sec. 14, T. 41 S., R. $81 \frac{1}{2}$ E., Kane County, Utah.

$\mathrm{SE}^{1 / 4}$ sec. 12, T. 42 S., R. 8 E., Kane County, Utah.

Measured at north end of east finger of Cummings Mesa, about $8 \mathrm{~km} \mathrm{~S} .5^{\circ} \mathrm{W}$., of Navajo Point, San Juan County, Utah.

Measured on northwest side of Tsai Skizzi Rock, a prominent isolated butte about $33.8 \mathrm{~km} \mathrm{S.} 68^{\circ}$ E. of Page, Coconino County, Ariz.

Measured in small tributary canyon to Potato Canyon about $1 \mathrm{~km}$ east and southeast of Square Butte and about $22.5 \mathrm{~km} \mathrm{~N} .22^{\circ} \mathrm{W}$. of Cow Springs Trading Post, Coconino County, Ariz.

Measured about $2.1 \mathrm{~km}$ east of Cow Springs Trading Post, Coconino County, Ariz.

47. Dinnehotso Near Dinnehotso, Apache County, Ariz. Harshbarger and others (1957, p. 65, sec. 6 ; plates 2 and 3 ).

48. Red Rock
Near Red Rock, Apache County, Ariz. Harshbarger and others (1957, pl. 2). 


\section{MEASURED SECTIONS}

Section 1.-Reference section of Carmel Formation and Page Sandstone at Pine Creek

[Measured on west side of valley of Pine Creek about $4.8 \mathrm{~km}$ north of Escalante in the $\mathrm{N}^{1 / 2} \mathrm{SW}^{1 / 4} \mathrm{SW}^{1 / 4}$ sec. $29, \mathrm{E}^{1 / 2} \mathrm{SE}^{1 / 4} \mathrm{SE}^{1 / 4}$ sec. 30 , T. $34 \mathrm{~S}$., R. $3 \mathrm{E}$. (projected), Garfield County, Utah]

Entrada Sandstone (part):

Lower member (part):

42. Sandstone, silty, moderate-reddish-orange, coarse silt size to very fine grained, moderately to poorly sorted, very thin to thick bedded; lower contact sharp and nearly planar; forms slopes .............................. 39.0

Carmel Formation:

Upper member:

41. Marker bed: mudstone, grayish-purple, laminated to very thin bedded, probably a bentonite bed; forms slope ..................

40. Sandstone, moderate-reddish-brown, very fine grained, moderately sorted; some ripple crosslamination apparent; forms slight ledge ......

39. Mudstone, dark-reddish-brown, laminated to very thin bedded; forms slope .............

38. Sandstone, moderate-reddish-brown, very fine grained, moderately sorted, irregularly very thin bedded and ripple cross-laminated; forms ledge ...............................

37. Sandstone, silty, moderate-reddish-brown, coarse silt to very fine grained, moderately to poorly sorted; bedding not apparent; forms slope .............................

36. Gypsum, mainly light gray but includes some moderate-reddish-brown and grayish-yellowgreen, laminated to very thin bedded, locally contorted; forms ledge ...................

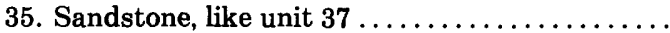

34. Mudstone, grayish-purple, some grayish-yellowgreen; forms slope ...................

33. Sandstone, light-gray at top to moderatereddish-brown at base, mottled in middle, very fine grained, moderately sorted, very thin bedded; forms slope .....................

32. Gypsum, like unit $36 ; 1.8 \mathrm{~m}$ above base is $0.9-\mathrm{m}$ bed of moderate-reddish-brown, slope-forming, silty sandstone .......................

31. Sandstoné, like unit $37 \ldots \ldots \ldots \ldots \ldots \ldots \ldots \ldots$

30. Gypsum, like unit $36 \ldots \ldots \ldots \ldots \ldots \ldots \ldots$

29. Mudstone, grayish-brown, dark-reddish-brown, and grayish-yellow-green; $1.5 \mathrm{~m}$ above base is 0.6-m bed of gypsum like unit 36; forms slope .

28. Gypsum, like unit 36 ; includes about 20 percent dark-reddish-brown mudstone; badly contorted; forms cliff ......................

27. Gypsum, like unit 36 but badly contorted; about $0.9 \mathrm{~m}$ above base is $0.9-\mathrm{m}$ bed of dark-reddishbrown mudstone; poorly exposed; forms slope

26. Mudstone, dark-reddish-brown, irregularly laminated to very thin bedded; includes about 30 percent moderate-reddish-brown silty sandstone; $6.7 \mathrm{~m}$ above base is $0.6 \mathrm{~m}$ of gypsum like unit 36; overlain by $1.2 \mathrm{~m}$ of laminated gray limestone and $0.9 \mathrm{~m}$ of grayish-yellow-green mudstone. The gypsum and limestone form a slight ledge; the remainder forms a slope .... 14.6
Section 1.-Reference section of Carmel Formation and Page Sandstone at Pine Creek-Continued

Carmel Formation-Continued

Upper member-Continued

Thickness

meters

25. Partly covered slope; some light-gray gypsum and very light gray limestone weathering out on the slope ...........................

24. Gypsum, like unit 36 ; includes about 30 percent dark-reddish-brown mudstone; generally forms slope although several gypsum beds form ledges .

3. Sandstone, very light gray, very fine grained, moderately sorted, very thin bedded; forms slope ...............................

22. Partly covered slope, mainly dark reddish brown mudstone and some moderate-reddish-brown silty sandstone $\ldots \ldots \ldots \ldots \ldots \ldots \ldots \ldots, 17$

21. Gypsum, like unit 36; exposed as a series of small hills and knobs that extend along the partly covered floor of a small gully ........ 1.5

20. Partly covered slope, mainly dark reddish brown

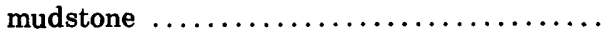

19. Marker bed: limestone, yellowish-gray, microcrystalline to very fine grained, very thin to thin-bedded, locally very low angle, small-scale crossbedded; top $15 \mathrm{~cm}$ contains several poorly preserved pelecypods identified as Pronoella uintahensis Imlay by R. W. Imlay (written commun., 1969); weathers to slabby cliffs and forms a small hogback ................ 15.2

18. Partly covered slope, mainly dark reddish brown mudstone grading to grayish-yellow-green in upper $0.9 \mathrm{~m}$ above base, suggesting a thin limestone bed at top...................

17. Limestone, light-gray, microcrystalline, very thin bedded; forms flaggy cliffs . . . . . . . . .

16. Partly covered slope, mainly dark reddish brown

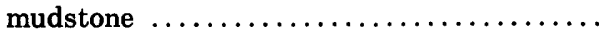

15. Partly covered slope, mainly yellowish gray, very thin bedded limestone includes some grayish-yellow mudstone; lower contact apparently planar $\ldots \ldots \ldots \ldots \ldots \ldots \ldots \ldots, 0.9$

Total upper member of Carmel Formation . 113.4

Page Sandstone

Thousand Pockets Tongue:

14. Sandstone, very light gray to pale-yellowishorange at top, fine-grained, well-sorted; consists of tabular-planar and wedge-planar sets of large-scale low- and high-angle cross-strata; basal $0.6 \mathrm{~m}$ locally slumped; forms smooth cliff

13. Marker bed: sandstone, moderate-reddish-brown, very fine grained, moderately sorted, irregularly very thin to thin-bedded; forms slope .........

12. Sandstone, light-gray, very fine grained, moderately sorted, very thin to thin-bedded; forms cliff $\ldots \ldots \ldots \ldots \ldots \ldots \ldots \ldots \ldots \ldots \ldots, 2.0$ 
Section 1.-Reference section of Carmel Formation and Page Sandstone at Pine Creek-Continued

Page Sandstone-Continued

Thousand Pockets Tongue-Continued

11. Sandstone, moderate-reddish-brown; grades to light-gray and pale-yellowish-orange at top; very fine grained, well-sorted. Consists of tabular-planar and wedge-planar sets of largescale, low-and high-angIe, cross-strata; Iower 9.6 $\mathrm{m}$ is irregularly very thin bedded; basal contact placed at sharp change in lithology; forms smooth cliff $\ldots \ldots \ldots \ldots \ldots \ldots \ldots \ldots \ldots \ldots, 11.3$

TotaI Thousand Pockets Tongue of Page Sandstone $\ldots \ldots \ldots \ldots \ldots \ldots \ldots \ldots \ldots \ldots$

CarmeI Formation: Judd Hollow Tongue:

10. Partly covered slope, mainly dark reddish brown mudstone; includes some moderate-reddishbrown silty sandstone; top $15 \mathrm{~cm}$ is grayishpurple bentonite; bedding not apparent .......

9. Limestone, yellowish-gray, very fine grained, silty and sandy, ripple cross-laminated; forms flaggy cliff ...

8. Interbedded unit: sandstone (about 50 percent) moderate-reddish-brown, fine-grained, moderately sorted; mudstone (about 40 percent), dark-reddish-brown; and limestone, moderate-reddish-brown; very thin to thinbedded; about $3 \mathrm{~m}$ above base is $0.3-\mathrm{m}$ bed of grayish-purple mudstone; forms slope ........

7. Limestone, very pale orange, very fine grained, sandy and silty, irregularly very thin bedded; forms flaggy ledge..$\ldots \ldots \ldots \ldots \ldots \ldots \ldots$.

6. Sandstone, light-gray to grayish-orange, finegrained, irregularly laminated to very thin bedded; forms slope .....................

5. Sandstone, light-gray, fine-grained, moderately to well-sorted, laminated to small-scale very low angle crossbedded; forms ledge ............

4. Sandstone, light-gray to grayish-orange, finegrained, moderately sorted, irregularly laminated to very thin bedded; forms notch or

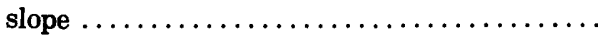

3. Sandstone, light-gray, stained moderateyellowish-brown, very fine grained, moderately sorted, irregularly very thin bedded; contains several slumped beds; lower contact sharp and planar; forms flaggy cliff . ............... Total Judd Hollow Tongue of Carmel Formation $\ldots \ldots \ldots \ldots \ldots \ldots \ldots \ldots \ldots \ldots \ldots .6 \ldots .6 \ldots$

Page Sandstone:

Harris Wash Tongue:

2. Sandstone, light-gray, some moderate-reddish brown, fine- to medium-grained, well-sorted; bedding consists of tabular-planar and troughshaped sets of large-scale low- and high-angle cross-strata; scarce angular very fine to fine pebbles of pale-brown to grayish-red chert scattered along base; lower contact sharp and planar; regional studies indicate it is an unconformity; forms cliff; base locally forms slight

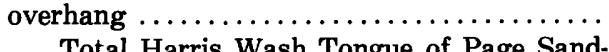

Total Harris Wash Tongue of Page Sandstone $\ldots \ldots \ldots \ldots \ldots \ldots \ldots \ldots \ldots \ldots, 4.6$
Thickness meters

Section 1.-Reference section of Carmel Formation and Page Sandstone at Pine Creek-Continued

Unconformity.

Navajo Sandstone (part):

\section{Thickness}

meters

1. Sandstone, light-gray, fine-grained, well-sorted; consists of tabular-planar and wedge-planar sets of large-scale Iow- and high-angle crossstrata; forms blocky cliffs ............. $30.5+$

Total measured Navajo Sandstone . . . . .

Section 2a.-Reference section of Carmel Formation (upper member) at Page

[Measured near paved road on west side of valley of Wahweap Creek about $5 \mathrm{~km}$ north of Hayden Visitor Center at Glen Canyon Dam in the SW1/4 SW1/4 sec. 1, SE1/4SE $1 / 4$ sec. 2 T, 41 N., R. 8 E., Coconino County, Ariz.]

Entrada Sandstone (part):

24. Sandstone, very light gray, fine-grained, moderately to well-sorted; bedding consists of trough-shaped sets of medium- to large-scale high-angIe cross-strata; lower contact sharp, planar, and conformable; top eroded; forms small irregular cliffs and knobby slopes ....... TotaI measured Entrada Sandstone ...... 6.1

Carmel Formation:

Upper member:

23. Sandstone, silty, grayish-yellow-green, coarse silt to very fine grained, moderately to poorly sorted, irregularly very thin bedded; forms slope .............................

22. Mudstone, dark-reddish-brown, sandy, laminated to very thin bedded; contains several sandstone and silty sandstone beds, which are moderate reddish brown, coarse silt to very fine grained, moderately to poorly sorted, very thin to thin bedded; $9.1 \mathrm{~m}$ above base is $0.9-\mathrm{m}$ bed of very thin bedded white sandstone overlain by $15 \mathrm{~cm}$ of grayish-purple mudstone; $8.5 \mathrm{~m}$ above base is $0.3 \mathrm{~m}$ of very thin bedded white sandstone overlain by $15 \mathrm{~cm}$ of grayishpurple mudstone; $0.9 \mathrm{~m}$ above base is $15 \mathrm{~cm}$ of grayish-purple bentonite; forms slope ...... 13.5

21. Sandstone, moderate-reddish-brown; top $0.3 \mathrm{~m}$ is white, fine-grained, moderately sorted; contains scattered very coarse grains, irregularly very thin to thin bedded; $3.7 \mathrm{~m}$ above base is thin lens of dark-reddish-brown mudstone as much as $0.3 \mathrm{~m}$ thick; forms slopes with slabby cliff in middle .......................

20. Sandstone, moderate-reddish-brown, very fine grained, moderately sorted, irregularly very thin to thin-bedded; includes many Iaminae or very thin beds of silty sandstone or mudstone; $8.5 \mathrm{~m}$ above base is $5 \mathrm{~cm}$ of dark-reddish-brown mudstone; $7.3 \mathrm{~m}$ above base is $0.9 \mathrm{~m}$ of white crossbedded sandstone; $6.7 \mathrm{~m}$ above base is 15 cm zone with scattered very fine to fine pebbles; forms slabby slopes at base and slabby cliffs at top ........................

19. Sandstone, moderate-reddish-brown, finegrained, moderately sorted, contains scattered very fine pebbles; laminated to very thin bedded; 1.2 and $1.5 \mathrm{~m}$ above base are two $7-\mathrm{mm}$ thick laminae of grayish-purple mudstone; forms slope with slabby cliff at top .......... 
Section 2a.-Reference section of Carmel Formation (upper member) at Page-Continued

Carmel Formation-Continued

Upper member-Continued

18. Sandstone, moderate-reddish-brown, very fine grained, moderately sorted; several beds contain scattered very fine pebbles; bedding is laminated to very thin bedded or consists of tabular-planar sets of small- to medium-scale, low-angle cross-strata; includes minor darkreddish-brown mudstone; forms a series of slabby to blocky ledges ..................

17. Interbedded sandstone and mudstone; sandstone, grayish-purple, fine-grained, moderately sorted; mudstone, dark-reddish-brown to grayish-purple, very thin to thin-bedded; forms slope..$\ldots \ldots \ldots \ldots \ldots \ldots \ldots \ldots$.

16. Sandstone, very light gray, fine-grained, moderately sorted; bedding is indistinct; forms

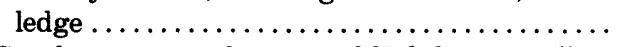

15. Sandstone, moderate-reddish-brown, finegrained, moderately sorted; contains scattered very fine pebbles, very thin bedded; forms slope ............................

14. Sandstone, pebbly, moderate-reddish-brown, fine-grained, poorly sorted; contains scattered very fine to fine pebbles and thin conglomerate lenses, irregularly very thin bedded; forms

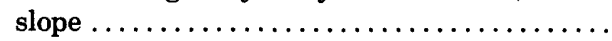

13. Sandstone, like unit $15 \ldots \ldots \ldots \ldots \ldots \ldots$

12. Sandstone, moderate-reddish-brown, finegrained, moderately sorted; contains scattered very fine pebbles, very thin bedded; slight ledge caps cliff . . . . . . . . . . . . . . . . .

11. Sandstone, moderate-reddish-brown, finegrained, well-sorted; consists of a tabularplanar set of large-scale high-angle crossstrata; forms smooth cliff ...............

10. Sandstone, moderate-reddish-brown, finegrained, moderately sorted; contains scattered very fine pebbles laminated to very thin bedded; top $0.9 \mathrm{~m}$ includes several very thin beds of dark-reddish-brown mudstone, some of which have sandstone-filled mudcracks; $5.5 \mathrm{~m}$ above base is $0.3-\mathrm{m}$ bed of dark-reddish-brown shale containing sandstone-filled mudcracks, overlain by $2.1-\mathrm{m}$ sandstone bed that is locally crossbedded and contains scarce scattered mudchips; $4.3 \mathrm{~m}$ above base is $0.3-\mathrm{m}$ bed of dark-reddish-brown shale; $0.9 \mathrm{~m}$ above base is 2.5-cm bed of dark-reddish-brown shale; generally forms slabby to blocky cliffs but includes several slopes ..................

9. Sandstone, moderate-reddish-brown, very fine grained, moderately sorted, very thin bedded; includes several very thin beds of darkreddish-brown mudstone; forms slope ........

8. Sandstone, moderate-reddish-brown, finegrained, moderately sorted; contains scattered coarse and very coarse grains; bedding is laminated to very thin bedded or consists of scarce tabular-planar sets of medium-scale high-angle cross-strata; includes scarce very thin beds of dark-reddish-brown shale and
Section 2a.-Reference section of Carmel Formation (upper member) at Page-Continued

Carmel Formation-Continued

Upper member-Continued

Thickness Thickness
meters

Carmel Formation (part):

Upper member (part):

9. Sandstone, dark-reddish-brown, fine-grained, moderately sorted; contains scattered very fine pebbles, very thin bedded to thin bedded; includes some sandy mudstone; forms ledges and slopes $\ldots \ldots \ldots \ldots \ldots \ldots \ldots \ldots \ldots \ldots .6 .6 \ldots \ldots$

8. Mudstone, dark-reddish-brown, sandy, laminated to very thin bedded; forms slope ...... 2.0

Page Sandstone (part):

1. Sandstone, moderate-pink, fine-grained, wellsorted; consists of tabular-planar and wedgeplanar sets of large-scale low- and high-angle ross-strata; forms smooth slopes and cliffs .. $30.0+$

Total measured Page Sandstone .......

Section 2b.-Type section of Page Sandstone

Measured on northwest side of Manson Mesa and the town of Page in the SW1/4 NW1/4 sec. 19, T. 41 N., R. 9 E., (projected), Coconino County, Ariz. Base of section is about $914 \mathrm{~m}$ east-northeast from Glen Canyon Dam and line of section trends due east up small cleft in cliffs to VABM 4103, Antelope]

Thickness meters

$6.0+$
2.0

mudstone; forms slabby to blocky ledges and
slopes $\ldots \ldots \ldots \ldots \ldots \ldots \ldots \ldots \ldots \ldots \ldots \ldots \ldots$

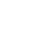

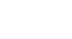


Section 2b.-Type section of Page Sandstone-Continued

Carmel Formation-Continued

Upper member-Continued

7. Sandstone, very light gray to grayish-pink, fine-grained, moderately sorted, irregularly very thin to thin-bedded, lower contact sharp and planar; generally covered by soil; forms slight ledge where exposed ............. 0.2

Total measured upper member of Carmel Formation

Page Sandstone:

6. Sandstone, moderate-reddish-orange to moderate-reddish-brown; grades to very light gray or grayish pink at top, fine grained, well sorted; scarce coarse grains occur at base of several cross-bedding sets; bedding consists of tabular-planar sets of medium- to large-scale, low- and high-angle cross-strata; forms smooth slopes or cliff rounded at top ............ 39.1

5. Sandstone, dark-reddish-brown, fine-grained, moderately sorted, irregularly very thin bedded; fossil joints at base extend about $0.6 \mathrm{~m}$ into underlying beds; forms local small bench or slight notch .........................

4. Sandstone, same as unit 6; grades to grayish red at top where small calcite or silicacemented sandstone nodules occur; forms smooth steep slopes or cliff ..............

3. Sandstone, dark-reddish-brown, fine-grained, moderately sorted, irregularly very thin bedded; forms local small bench or slight notch ...

2. Sandstone, moderate-reddish-orange to moderate-reddish-brown, fine-grained, well-sorted; scarce coarse grains occur at base of several crossbedding sets; bedding consists of tabularplanar sets of medium- to large-scale, low- and high-angle cross-strata; scattered along base are abundant angular very fine to fine pebbles of white to very pale orange chert or scarce red chert; fossil joints at base extend down about 1 $m$ into Navajo Sandstone; lower contact sharp and planar except at fossil joints; regional studies indicate an unconformity; forms smooth rounded cliffs ...................

Total Page Sandstone $\ldots \ldots \ldots \ldots \ldots \ldots, \underline{\mathbf{5 5 . 8}}$

Unconformity.

Navajo Sandstone (part):

1. Sandstone, pale-reddish-brown; grades down to moderate reddish brown, fine grained, well sorted; bedding consists of tabular-planar sets of medium- to large-scale, low- and high-angle cross-strata; small silica- and calcite-cemented sandstone nodules occur in upper $4.6 \mathrm{~m}$; forms smooth sheer cliffs in Glen Canyon but above the canyon has irregular bench a kilometer or more wide, stripped back on top .......... 15.2+

Total measured Navajo Sandstone......
Section 3.-Type section of Harris Wash Tongue of Page Sandstone [Measured on west side of Halfway Hollow about $0.8 \mathrm{~km}$ from junction with Harris Wash, about $20 \mathrm{~km}$ southeast of Escalante, Utah, in the $\mathrm{NE}^{1 / 4} \mathrm{SE}^{1 / 4} \mathrm{NE}^{1 / 4} / 4 \mathrm{sec}^{26}$, T. $36 \mathrm{~S}$., R. 4 E., Garfield County, Utah]

Carmel Formation (part):

Judd Hollow Tongue (part):

Thickness meters

5. Mudstone, dark-reddish-brown, laminated to very thin bedded; upper part involved in intraformational folds; forms slope ............

4. Sandstone, moderate-reddish-brown and grayish-red; top meter mottled with grayish pink fine grained, moderately to well sorted, irregularly laminated to very thin bedded; includes some small- to medium-scale, low-angle, wedge-planar cross-strata; forms slabby cliff .

Total measured Judd Hollow Tongue of Carmel Formation ............... 7.5

Page Sandstone (part):

Harris Wash Tongue:

3. Sandstone, moderate-reddish-brown and grayish-pink; grading upward to dominantly grayish pink, fine grained, well sorted; consists of tabular-planar and wedge-planar sets of medium- and large-scale, low- and high-angle cross-strata; top $15 \mathrm{~cm}$ is a set of low-angle, wedge-planar cross-strata; beneath that is a set of large-scale, high-angle cross-strata about $10.7 \mathrm{~m}$ thick; forms smooth cliff ...... 18.0

2. Sandstone, moderate-reddish-brown; includes some that is grayish pink and very light gray, fine grained, moderately sorted, laminated to very thin bedded and ripple cross laminated; scattered along base are angular very fine pebbles of white to very pale orange chert; fossil joints extend down as much as $1.2 \mathrm{~m}$ into the Navajo Sandstone; basal contact sharp and planar except at fossil joints; regional studies indicate it is an unconformity; forms smooth cliffs, locally stripped back slightly at base...

Total Harris Wash Tongue of Page Sandstone $\ldots \ldots \ldots \ldots \ldots \ldots \ldots \ldots \ldots \ldots .18 .3$

Unconformity.

Navajo Sandstone (part):

1. Sandstone, grayish-pink to moderate-reddishbrown, fine-grained, well-sorted; consists of tabular-planar and wedge-planar sets of medium- to large-scale, low- and high-angle cross-strata; forms smooth cliff ........... $6.1+$

Total measured Navajo Sandstone...... 6.0

Section 4.-Principal reference section of Temple Cap Sandstone, type section of Sinawava and White Throne Members

[Measured at top of Zion Canyon about $500 \mathrm{~m}$ northeast of Observation Point in the NW1/4NW1/4 sec. 2, T. 41 S., R. $10 \mathrm{~W}$. (projected), Zion National Park, Washington County, Utah]

Carmel Formation (part):

Limestone member (part):

Thickness Meters

Limestone unit (part):

10. Limestone, very pale orange, microcrystalline to very fine grained, thin- to thickbedded, locally laminated to very thin bedded; forms slabby ledges; top eroded, only lower part present .................. 12.2+ Total measured limestone unit ..... $\underline{\underline{12.2}}$ 
Section 4.-Principal reference section of Temple Cap Sandstone, type section of Sinawava and White Throne Members-Continued Carmel Formation-Continued

Limestone member-Continued

Basal unit:

9. Interbedded mudstone and sandstone; mudstone, dark-reddish-brown, laminated to very thin bedded; sandstone and silty sandstone, moderate-reddish-brown to grayish-pink, coarse silt, to fine-grained, moderately sorted, very thin bedded; contains some pink limestone near top; forms a slope, generally partly concealed by thin veneer of talus of soil ................

8. Sandstone, moderate-reddish-brown, medium-grained; contains scattered rounded coarse grains of black, gray, or brown chert and red or clear quartz, and angular very coarse grains and very fine pebbles of white or pink chert, irregularly very thin to thin bedded; lower contact sharp and planar; regional studies indicate it is an unconformity; forms flaggy ledge ..........

Total basal unit .................

Total measured limestone member of Carmel Formation ...........

Temple Cap Sandstone:

White Throne Member:

7. Sandstone, yellowish-gray grading down to very light gray and very pale orange, fine-grained, well-sorted; consists of trough and tabularplanar sets of large-scale, low- and high-angle cross-strata; forms smooth cliff . . . . . . . . 26.5

6. Sandstone, grayish-yellow to pale-yellowishorange, very fine to fine-grained, scattered very coarse grains, moderately sorted; consists of tabular-planar and wedge-planar sets of medium-scale, low-angle cross-strata; forms irregular cliff; locally has a small shoulder at

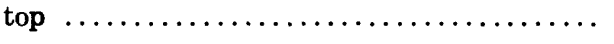

5. Sandstone, grayish-yellow to pale-yellowishorange, very fine to medium-grained; scattered coarse grains, moderately sorted, very thin bedded; includes tabular-planar sets of smallscale, low-angle cross-strata in lower $15 \mathrm{~cm}$; forms cliff .......................

4. Sandstone, very light gray and some moderatereddish-brown, mottled, fine-grained, moderately to well-sorted; consists of troughshaped sets of medium- to large-scale low- and high-angle cross-strata; lower contact gradational; unit varies in thickness owing to intraformational folds or slumps at or near the base; forms cliff . . . . . . . . . . . . . .

Total White Throne Member ........

Sinawava Member:

3. Interbedded sandstone, silty sandstone, and mudstone; sandstone and silty sandstone, moderate-reddish-brown, coarse silt to very fine grained, scattered coarse grains, moderately to poorly sorted, laminated to very thin bedded; mudstone, dark-reddish-brown, laminated to very thin bedded, more abundant near base of unit; unit varies in thickness owing to intraformational folds or slumps near top, largely concealed by talus and soil cover; forms slope .........................
Section 4.-Principal reference section of Temple Cap Sandstone, type section of Sinawava and White Throne Members-Continued

Temple Cap Sandstone-Continued

Sinawava Member-Continued

Thickness

2. Sandstone, very light gray to moderate-reddish-brown, mottled, very fine to fine-grained, scattered coarse and scarce very coarse grains, moderately to poorly sorted, irregular very thin bedding, basal contact sharp, nearly planar, but locally has about $15 \mathrm{~cm}$ relief; forms slope or slight ledge $\ldots \ldots \ldots \ldots \ldots \ldots, \underline{0.3}$

Total Sinawava Member ............. $\frac{0.1}{6.1}$

Total Temple Cap Sandstone ......... $\overline{\overline{55.8}}$

Navajo Sandstone (part):

1. Sandstone, white to very light gray, fine-grained, well-sorted; consists of tabular-planar and wedge-planar sets of large-scale, low- and highangle cross-strata; forms smooth cliff ....... 15.2

Total measured Navajo Sandstone......

\section{REFERENCES CITED}

Averitt, Paul, 1962, Geology and coal resources of the Cedar Mountain quadrangle, Iron County, Utah: U.S. Geol. Survey Prof. Paper 389, 72 p.

Baker, A. A., Dobbin, C. E., McKnight, E. T., and Reeside, J. B., Jr., 1927, Notes on the stratigraphy of the Moab region, Utah: Am. Assoc. Petroleum Geologists Bull., v. 11, no. 8, p. 785-808.

Baker, A. A., Dane, C. H., and Reeside, J. B., Jr., 1936, Correlation of the Jurassic formations of parts of Utah, Arizona, New Mexico, and Colorado: U.S. Geol. Survey Prof. Paper 183, 66 p.

Cashion, W. B., 1967, Carmel Formation of the Zion Park region, southwestern Utah-A review: U.S. Geol. Survey Bull. 1244-J, p. J1-J9.

Cornet, Bruce, Traverse, Alfred, and McDonald, N. G., 1973, Fossil spores, pollen, and fishes from Connecticut indicate Early Jurassic age for part of the Newark Group: Science, v. 182, p. 1243-1247.

Cornet, Bruce, and Traverse, Alfred, 1975, Palynological contributions to the chronology and stratigraphy of the Hartford basin in Connecticut and Massachusetts: Geoscience and Man, v. 11, p. 1-33.

Craig, L. C., and Dickey, D. D., 1956, Jurassic strata of southeastern Colorado, in J. A. Peterson, ed., Geology and economic deposits of east-central Utah: Intermountain Assoc. Petroleum Geologists Guidebook, 7th Ann. Field Conf., p. 93-104.

Crampton, C. G., 1964, Standing up country-The canyon lands of Utah and Arizona: New York, Alfred A. Knopf, Utah University Press, $191 \mathrm{p}$.

Davidson, E. S., 1967, Geology of the Circle Cliffs area, Garfield and Kane Counties, Utah: U.S. Geol. Survey Bull. 1229, 149 p.

Dunbar, C. O., and Rodgers, John, 1957, Principles of stratigraphy: New York, John Wiley and Sons, $356 \mathrm{p}$.

Galton, P. M., 1971, The prosauropod dinosaur Ammosaurus, the crocodile Protosuchus, and their bearing on the age of the Navajo Sandstone of northeastern Arizona: Jour. Paleontology, v. 45 , no. 5, p. 781-795.

Gilluly, James, and Reeside, J. B., Jr., 1928, Sedimentary rocks of the San Rafael Swell and some adjacent areas in eastern Utah: U.S. Geol. Survey Prof. Paper 150-D, p. 61-110.

Glennie, K. W., 1970, Desert sedimentary environments: New York, Elsevier, 222 p.

Goddard, E. N., chm., and others, 1963 reprint, Rock-color chart: New York, Geol. Soc. America, 6 p.

Grater, R. K., 1948, Some features of the Navajo Formation in Zion National Park, Utah: Am. Jour. Sci., v. 246, no. 5, p. 311-318.

Gregory, H. E., 1917, Geology of the Navajo country-a reconnaissance of parts of Arizona, New Mexico, and Utah: U.S. Geol. Survey Prof. Paper 93, 161 p. 1948, Geology and geography of central Kane County, Utah: 
Geol. Soc. America Bull., v. 59, no. 3, p. 211-247.

1950a, Geology and geography of the Zion [National] Park region, Utah and Arizona: U.S. Geol. Survey Prof. Paper 220, $200 \mathrm{p}$.

1950b, Geology of eastern Iron County, Utah: Utah Geol. Mineralog. Survey Bull. 37, 153 p.

1951, The geology and geography of the Paunsaugunt region, Utah: U.S. Geol. Survey Prof. Paper 226, 116 p.

Gregory, H. E., and Moore, R. C., 1931, The Kaiparowits region, a geographic and geologic reconnaissance of parts of Utah and Arizona: U.S. Geol. Survey Prof. Paper 164, 161 p.

Harshbarger, J. W., Repenning, C. A., and Irwin, J. H., 1957, Stratigraphy of the uppermost Triassic and the Jurassic rocks of the Navajo country [Colorado Plateau]: U.S. Geol. Survey Prof. Paper 291, 74 p.

Imlay, R. W., 1952, Correlation of the Jurassic formations of North America, exclusive of Canada: Geol. Soc. America Bull., v. 63, no. 9, p. 953-992.

1957, Paleoecology of Jurassic seas in the Western Interior of the United States, in H. S. Ladd, ed., Paleoecology: Geol. Soc. America Mem. 67, v. 2, p. 469-504.

1964, Marine Jurassic pelecypods from central and southern Utah: U.S. Geol. Survey Prof. Paper 483-C, p. C1-C42.

1967, Twin Creek Limestone (Jurassic) in the Western Interior of the United States: U.S. Geol. Survey Prof. Paper 540, 105 p.

1979, Jurassic paleobiogeography of conterminous United States and adjacent areas in its continental setting: U.S. Geol. Survey Prof. Paper 1062. (In press.)

Lewis, G. E., Irwin, J. H., and Wilson, R. F., 1961, Age of the Glen Canyon Group (Triassic and Jurassic) on the Colorado Plateau: Geol. Soc. America Bull., v. 72, no. 9, p. 1437-1440.

McKee, E. D., and Weir, G. W., 1953, Terminology for stratification and cross-stratification in sedimentary rocks: Geol. Soc. America Bull., v. 64, no. 4, p. 381-389.

McKee, E. D., Oriel, S. S., Swanson, V. W., MacLachlan, M. E., MacLachlan, J. C., Ketner, K. B., Goldsmith, J. W., Bell, R. Y., and Jameson, D. J., 1956, Paleotectonic maps of the Jurassic System: U.S. Geol. Survey Misc. Geol. Inv. Map I-175, 6 p.

Olsen, P. E., and Galton, P. M., 1977, Triassic-Jurassic tetrapod extinctions: are they real?: Science, v. 197, p. 983-986.

O'Sullivan, R. B., and Craig, L. C., 1973, Jurassic rocks of northeast Arizona and adjacent areas, in New Mexico Geol. Soc. 24th Ann. Field Conf. Guidebook of Monument Valley and Vicinity, Arizona and Utah: p. 79-85.

Peterson, Fred, 1973, Geologic map of the southwest quarter of the Gunsight Butte quadrangle, Kane and San Juan Counties, Utah, and Coconino County, Arizona: U.S. Geol. Survey Misc. Field Studies Map MF-306.

Peterson, Fred, and Waldrop, H. A., 1965, Jurassic and Cretaceous stratigraphy of south-central Kaiparowits Plateau, Utah, in Geology and resources of south-centraI Utah-Resources for power: Utah Geol. Soc. Guidebook to Geology of Utah, no. 19, p. 47-69.

Peterson, Fred, and Barnum, B. E., 1973, Geologic map of the southwest quarter of the Cummings Mesa quadrangle, Kane and San Juan Counties, Utah, and Coconino County, Arizona: U.S. Geol. Survey Misc. Geol. Inv. Map I-759.

Phoenix, D. A., 1963, Geology of the Lees Ferry area, Coconino County, Arizona: U.S. Geol. Survey Bull. 1137, 86 p.

Pipiringos, G. N., 1967, Jurassic and Triassic of Wyoming and southern Rockies [abs.]: Am. Assoc. Petroleum Geologists Bull., v. 51, no. 9, p. 1904-1905.

1968, Correlation and nomenclature of some Triassic and Jurassic rocks in south-centraI Wyoming: U.S. Geol. Survey Prof. Paper 594-D, p. D1-D26.

Pipiringos, G. N., and O'Sullivan, R. B., 1975, Chert pebble unconformity at the top of the Navajo Sandstone in southeastern Utah, in J. E. Fassett, ed., Canyonlands Country: Four Corners Geol. Soc. Guidebook, 8th Field Conf., p. 149-156.
1978, Principal unconformities in Triassic and Jurassic rocks, Western Interior United States-A preliminary survey: U.S. Geol. Survey Prof. Paper 1035-A, 29 p.

Poole, F. G., and Stewart, J. H., 1964, Chinle Formation and Glen Canyon Sandstone in northeastern Utah and northwestern Colorado: U.S. Geol. Survey Prof. Paper 501-D, p. D30-D39.

Reeside, J. B., Jr., and Bassler, Harvey, 1922, Stratigraphic section in southwestern Utah and northwestern Arizona: U.S. Geol. Survey Prof. Paper 129-D, p. 53-77.

Shawe, D. R., Simmons, G. C., and Archbold, N. L., 1968, Stratigraphy of Slick Rock district and vicinity, San Miguel and Dolores Counties, Colorado: U.S. Geol. Survey Prof. Paper 576-A, p. A1-A108 [1969].

Smith, J. F., Jr., Huff, L. C., Hinrichs, E. N., and Leudke, R. G., 1963, Geology of the Capitol Reef area, Wayne and Garfield Counties, Utah: U.S. Geol. Survey Prof. Paper 363, 102 p.

Speed, R. C., 1976, Geologic map of the Humboldt Lopolith and surrounding terrane, Nevada: Geol. Soc. America, Map MC-14.

Speed, R. C., and Jones, T. A., 1969, Synorogenic quartz sandstone in the Jurassic mobile belt of western Nevada: Boyer Ranch Formation: Geol. Soc. America Bull., v. 80 , no. 12 , p. 2551-2584.

Thaden, R. E., Trites, A. F., Jr., and Finnell, T. L., 1964, Geology and ore deposits of the White Canyon area, San Juan and Garfield Counties, Utah: U.S. Geol. Survey Bull. 1125, 166 p.

Thompson, A. E., and Stokes, W. L., 1970, Stratigraphy of the San Rafael Group, southwest and south-central Utah: Utah GeoI. Mineralog. Survey Bull. 87, 50 p. (replacement copy issued May 1971).

Walker, A. D., 1968, Protosuchus, Proterochampsa, and the origin of phytosaurs and crocodiles: Geological Magazine, v. 105, no. 1, p. 1-14.

Walker, T. R., and Harms, J. C., 1972, Eolian origin of flagstone beds, Lyons Sandstone (Permian), type area, Boulder County, CoIorado: The Mountain Geologist, v. 9, nos. 2-3, p. 279-288.

Williams, G. A., 1954, Stratigraphic studies: U.S. Atomic Energy Comm., Trace Element Investigations Report TEI-440, p. 30-35.

Wilson, R. F., 1965, Triassic and Jurassic strata of southwestern Utah, in Geology and resources of south-central Utah-Resources for power: Utah Geol. Soc. Guidebook to Geology of Utah, no. 19, p. 31-46.

1967, Whitmore Point, a new member of the Moenave Formation in Utah and Arizona: Plateau, v. 40, no. 1, p. 29-40.

1974, Mesozoic stratigraphy of northeastern Arizona; in T.N.V. Karlstrom, Swann, G. A., and Eastwood, R. L., eds., Geology of northern Arizona with notes on archaeology and paleoclimate, Part 1, Regional Studies: Northern Arizona University, Museum of Northern Arizona, and U.S. Geol. Survey, p. 192-207.

Wilson, R. F., and Stewart, J. H., 1967, Correlation of Upper Triassic and Triassic(?) formations between southwestern Utah and southern Nevada: U.S. Geol. Survey Bull. 1244-D, p. D1-D20.

Woodbury, A. M., 1950, A history of southern Utah and its national parks: Utah State Hist. Soc. Quart., v. 12, nos. 3-4, p. 111-223 [July-October 1944, revised and reprinted 1950].

Wright, J. C., and Dickey, D. D., 1963a, Relations of the Navajo and Carmel Formations in southwest Utah and adjoining Arizona, in Geological Survey research 1962, Short papers in geology, hydrology, and topography: U.S. Geol. Survey Prof. Paper 450-E, p. E63-E67.

1963 b, Block diagram of the San Rafael Group and underlying strata in Utah and part of Colorado: U.S. Geol. Survey Oil and Gas Inv. Chart OC-63.

Young, R. G., 1964, An unusual sedimentary structure from the Carmel Formation: Jour. Sed. Petrology, v. 34, no. 4, p. 883-886.

Zeller, H. D., 1973, Geologic map and coal resources of the Dave Canyon quadrangle, Garfield County, Utah: U.S. Geol. Survey Coal Map C-59. 

IIYI

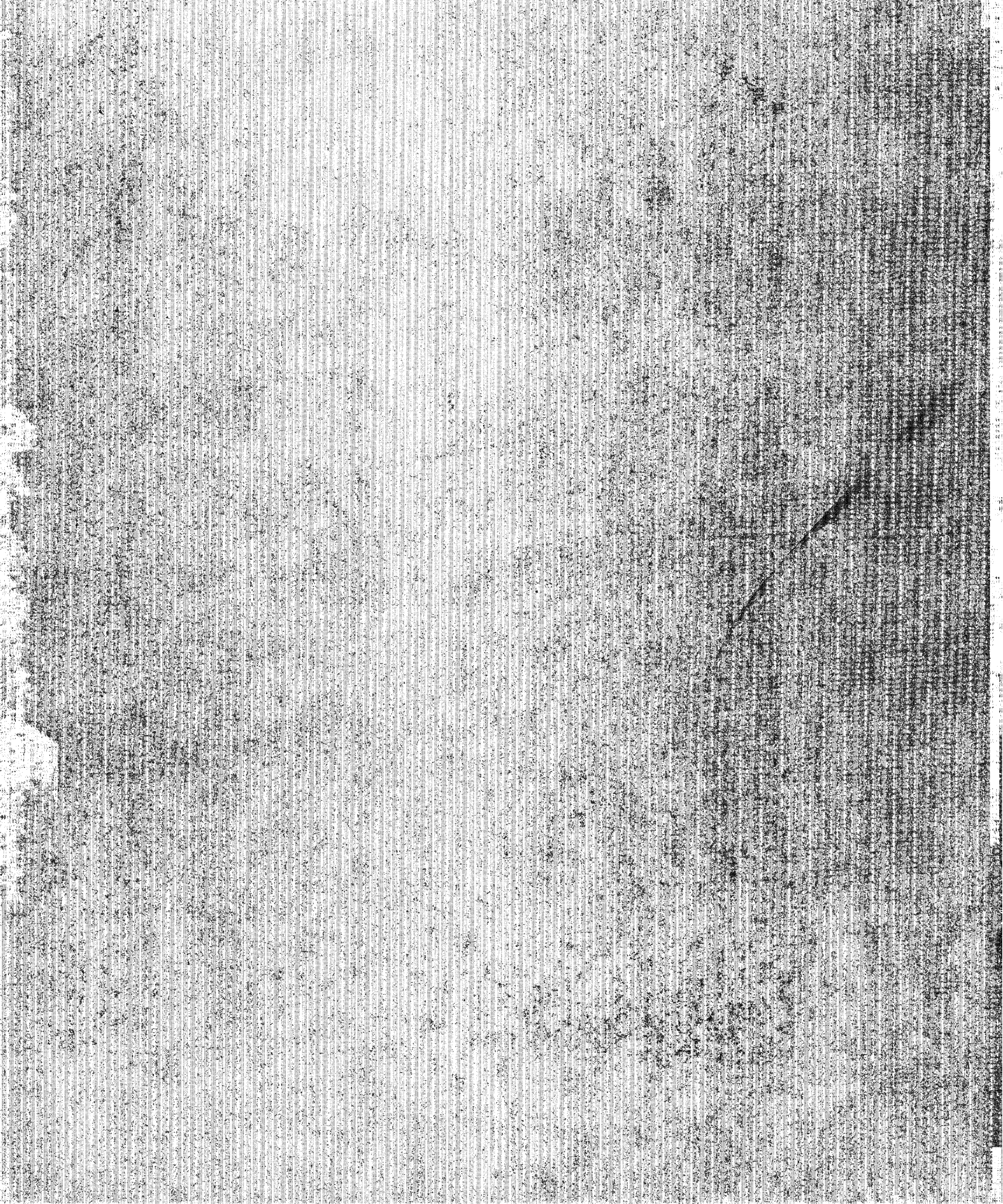

